\title{
GUIDANCE FOR INVESTING IN DIGITAL HEALTH
}

Peter Drury, Susann Roth, Tom Jones, Michael Stahl, Donna Medeiros

NO. 52

May 2018
ADB SUSTAINABLE DEVELOPMENT WORKING PAPER SERIES 


\section{ADB Sustainable Development Working Paper Series}

\section{Guidance for Investing in Digital Health}

Peter Drury, Susann Roth, Tom Jones, Michael Stahl, Donna Medeiros

No. 52 | May 2018
Peter Drury is an international specialist in digital health and development strategies.

Susann Roth is a medical doctors and a Senior Social Development Specialist at ADB, leading ADB's digital health work.

Tom Jones is Director of Strategy and Impact at the African Centre for eHealth Excellence, and evaluated the socioeconomic and affordability impact of over 60 projects using the DHIF methodology.

Michael Stahl focuses on social health protection, health insurance management, digital health and identification mechanisms.

Donna Medeiros is global health informatics advisor specializing in national digital health implementation. 
(C) 2018 Asian Development Bank

6 ADB Avenue, Mandaluyong City, 1550 Metro Manila, Philippines

Tel +63 2632 4444; Fax +6326362444

www.adb.org

Some rights reserved. Published in 2018.

Publication Stock No. WPS179150-2

DOI: http://dx.doi.org/10.22617/WPS179150-2

The views expressed in this publication are those of the authors and do not necessarily reflect the views and policies of the Asian Development Bank (ADB) or its Board of Governors or the governments they represent.

$A D B$ does not guarantee the accuracy of the data included in this publication and accepts no responsibility for any consequence of their use. The mention of specific companies or products of manufacturers does not imply that they are endorsed or recommended by ADB in preference to others of a similar nature that are not mentioned.

By making any designation of or reference to a particular territory or geographic area, or by using the term "country" in this document, $A D B$ does not intend to make any judgments as to the legal or other status of any territory or area.

This work is available under the Creative Commons Attribution 3.0 IGO license (CC BY 3.0 IGO) https://creativecommons.org/licenses/by/3.0/igo/. By using the content of this publication, you agree to be bound by the terms of this license. For attribution, translations, adaptations, and permissions, please read the provisions and terms of use at https://www.adb.org/terms-use\#openaccess.

This CC license does not apply to non-ADB copyright materials in this publication. If the material is attributed to another source, please contact the copyright owner or publisher of that source for permission to reproduce it. $A D B$ cannot be held liable for any claims that arise as a result of your use of the material.

Please contact pubsmarketing@adb.org if you have questions or comments with respect to content, or if you wish to obtain copyright permission for your intended use that does not fall within these terms, or for permission to use the ADB logo.

Notes:

In this publication, “\$” refers to US dollars.

Corrigenda to ADB publications may be found at http://www.adb.org/publications/corrigenda.

ADB recognizes "South Korea" as "the Republic of Korea". 


\section{CONTENTS}

Tables, Figures, and Boxes $\quad v$

Abbreviations

Foreword $\quad$ viii

Summary

Key Points $\quad x$

$\begin{array}{ll}\text { I. Context } & 1\end{array}$

A. Development, Health, and Information and Communication Technology 1

B. Sustainable Development Goals, Universal Health Coverage, and Digital Health 5

$\begin{array}{ll}\text { II. Supporting Stakeholders with Strategy and Architecture } & 7\end{array}$

$\begin{array}{ll}\text { A. Health Systems } & 7\end{array}$

$\begin{array}{ll}\text { B. Stakeholders } & 8\end{array}$

$\begin{array}{ll}\text { C. Strategy } & 9\end{array}$

$\begin{array}{ll}\text { D. Architecture } & 10\end{array}$

III. Stakeholders, and the Cycle of Change for Making Digital Health Investments 13

$\begin{array}{ll}\text { A. Cycle of Change } & 13\end{array}$

B. The Public (and Patients) 16

C. Health Workers (including Doctors, Nurses, Pharmacists, and Diagnostic Teams) 17

D. Health Managers 19

$\begin{array}{ll}\text { E. Payers } & 22\end{array}$

F. Investors and Donors $\quad 23$

G. Planners and Policymakers $\quad 24$

H. Governance $\quad 26$

IV. Digital Health Investment Process $\quad 27$

$\begin{array}{ll}\text { A. Introduction } & 27\end{array}$

B. Digital Health Investment Case Cycle $\quad 28$

C. Building a Digital Health Investment Case 33

D. Requirements, Solutions, and Benefits $\quad 40$ 
iv $\quad$ ADB Sustainable Development Working Paper Series No. 52

V. Forward Look $\quad 45$

A. Near Future: Challenges in Developing the Infrastructure 45

$\begin{array}{ll}\text { B. Digital Technology } & 47\end{array}$

C. Fourth Industrial Revolution and Health $\quad 49$

D. Understanding the Impact of Technology on Jobs in the Health Sector 51

$\begin{array}{ll}\text { VI. Next Steps } & 52\end{array}$

Appendixes

1: Key Definitions

2: Digital Health Impact Framework 56

$\begin{array}{ll}\text { 3: Toolkits } & 60\end{array}$

4: Potential Areas for Saving Costs and Increasing Benefits 62

5: Journey to Better Data for Better Health in Tanzania 72

$\begin{array}{ll}\text { References } & 73\end{array}$ 


\section{TABLES, FIGURES, AND BOXES}

\section{Tables}

1 Potential Priorities for Infrastructure Development 4

2 Benefit Pathways: Examples from Delivering Better Quality of Care, and Key Strategic Investments $\quad 27$

3 Comparison of Five illustrative Digital Health Investment Models Over 10 years 37

4 Stakeholder Requirements for Digital Health Services; Associated Management and Technical Support; and Potential Benefits 41

5 Differing Views on the Big Data Approach 48

A5 Investment Recommendation Cost Estimates $\quad 72$

\section{Figures}

1 Virtuous Cycle: Healthy Life Years for Continuous Economic Growth 2

2 Investing in Digital Solutions Supports Productivity 3

3 Potential Priorities for Infrastructure Deployment 5

4 Impact of Digital Health 6

5 Complex Web of Actors for Digital Health to Deliver Benefits 7

6 Health Insurance System and eGovernment Connected by Interoperable Digital Systems 8

7 Stakeholders Benefit from Well-Defined eHealth/Digital Health Strategy 9

8 From Managing Health Organizations to Enabling Informed Stakeholders 12

9 Cycle of Change for Making Investments in Digital Health 13

10 Public and Patients: Key Questions and Requirements 16

11 Health Workers: Key Questions and Requirements 18

12 Health Workers Support for Continuity of Care 19

13 Health Managers: Key Questions and Requirements 20

14 Different Types of Decision for Different Types of Digital Solutions 20

15 To Support the Continuity of Care, Health Information Needs to be Exchanged 21

16 Payers: Key Questions and Requirements 22

17 Investors and Donors: Key Questions and Requirements 23

18 Planners and Policymakers: Key Questions and Requirements 25

19 Different Options for Managing the Development and Delivery Process 26

20 Investment Case Framework 28

21 Digital Health Investment Profiles $\quad 29$ 
22 Digital Health Investment Cycle 30

23 Foundations for Delivering Benefits

24 Stakeholders Shared Requirements 32

2510 Key Steps in Developing a Digital Health Impact Framework 35

265 -Year Socioeconomic Return Net Benefits (Example) 38

27 Cumulative Socioeconomic Returns of 36 Digital Health Initiatives 39

28 Foundations for Cumulative Stakeholder Benefits and Better Socioeconomic Return $\quad 40$

29 Important Barriers to be Overcome in the Short Term 46

30 Health Care Data Lake $\quad 47$

31 Just Beginning: Digitalization of Health 48

32 Health System Goals for Implementation of Technological Innovation 50

33 Expectations of What Can Be Delivered 51

34 First Steps 54

A2.1 Electronic Health Records Capital Expenditure Annual Cost and Benefits 58

A2.2 Electronic Health Records Cumulative eHealth Information Risk-Adjusted Capital Expenditure 59

\section{Boxes}

1 Thailand Identity Management 10

2 Nepal: Taking Stock of Health Workers' Record Keeping 18

3 Philippine Health Insurance 23

4 Investor Perspectives on Digital Health Return on Investment 24

5 Return on Investment in Prevention $\quad 25$

6 Principles for Digital Development 26 


\section{ABBREVIATIONS}

\begin{tabular}{|c|c|}
\hline $4 I R$ & Fourth Industrial Revolution \\
\hline$A \& E$ & assumptions and estimates \\
\hline ADB & Asian Development Bank \\
\hline AeHIN & Asia eHealth Information Network \\
\hline $\mathrm{CHF}$ & congestive heart failure \\
\hline CRVS & civil registration and vital statistics \\
\hline DHIF & digital health impact framework \\
\hline EHR & electronic health record \\
\hline EPR & electronic patient/(medical) record \\
\hline HIE & health information exchange \\
\hline HL7 FHIR & Health Level 7 Fast Healthcare Interoperability Resources \\
\hline ICT & information and communication technology \\
\hline IDP & international development partner \\
\hline IOT & internet of things \\
\hline$M \& E$ & monitoring and evaluation \\
\hline MIS & management information system \\
\hline MNO & mobile network operator \\
\hline PATH & Program for Appropriate Technology in Health \\
\hline POC & point of care \\
\hline PPP & public-private partnership \\
\hline $\mathrm{ROI}$ & return on investment \\
\hline SDG & Sustainable Development Goal \\
\hline SMS & short message service \\
\hline UHC & universal health coverage \\
\hline VFM & value for money \\
\hline WHO & World Health Organization \\
\hline
\end{tabular}




\section{FOREWORD}

Who is this document for? Those who need to brief decision-makers about the issues to be considered when making small or large investments in digital health. These decision-makers may be senior government officials, but this document is also intended to be of use to those within the health system (e.g., health managers), or to those supporting the health system (e.g., donors).

What is the purpose of this document? In addition to being a guide on how to think about the digital health investment process, a further purpose of this document is to help digital health specialists tasked with assembling the data needed to enable a well-informed investment decision to be made. A digital health impact framework (DHIF) is introduced to do this. A document supporting DHIF manual and spreadsheets illustrating five use cases are also being published.

What is the expected outcome of this document? Governments will reflect on their understanding of the issues involved in maximizing the benefits and minimizing the risks of digital health by developing well-formed digital health strategies and associated investment plans, and will ensure that digital health investments, large or small, take advantage of the DHIF approach in the appropriate level of detail.

Who prepared the document? The development of the paper was led by the consultants Peter Drury, Michael Stahl and Tom Jones and the ADB team leader Susann Roth with support from Donna Medeiros. A team of experts from the Asia ehealth Information Network (AeHIN) and the Standards and Interoperability Lab Asia (SIL-A) led by Alvin Marcelo and Philip Zuniga provided input, validated and tested the usefulness of the guidance document. A regional consultation workshop attended by several country representatives from Malaysia, Myanmar, Thailand, Taipei,China, Philippines, and Viet Nam was held in January in Bangkok and led to the endorsement of the core content of the document. The ADB health sector team provided also valuable input and ensured relevance in the ADB context. The figures in this document were designed by Keisuke Taketani. We thank all contributors for making this document practical and useful. 


\section{SUMMARY}

Digital technologies are increasingly underpinning almost all aspects of daily life, including health care. But there is not yet sufficient awareness of the issues to be considered when investing in digital technologies to improve systems as complex as health.

The overarching goal is to meet the Sustainable Development Goals (SDGs) and, in particular, universal health coverage (UHC) by investing in digital health. Health care systems in both developed and developing nations have begun to embrace the transformative power of information and communication technology, from electronic health records that integrate and organize medical data and enable providers to share it easily, to mobile technology that spurs better informed decisions by people and health workers in rural areas and hospitals. There are many digital health solutions already in place, and many are planned. The question is what investments in knowledge, people, policies, and equipment will maximize the impact of digital health?

Some investments in digital health are best carried out by governments. Other stakeholders can then build their digital health solutions on these. This paper aims to help governments consider the interests of all those stakeholders when planning investments in digital health. It also provides a digital health impact framework, illustrated with five cases, to show how to assess costs, benefits, and timescales; manage expectations; and ensure affordable strategies.

Looking to the future, strengthening health systems to support UHC and meet the SDGs faces some implementation barriers. This, in turn, requires clarifying the principles (such as people- centered care) that will guide the future implementation of the technology, and its impact on jobs. The diagram below summarizes the key concepts.

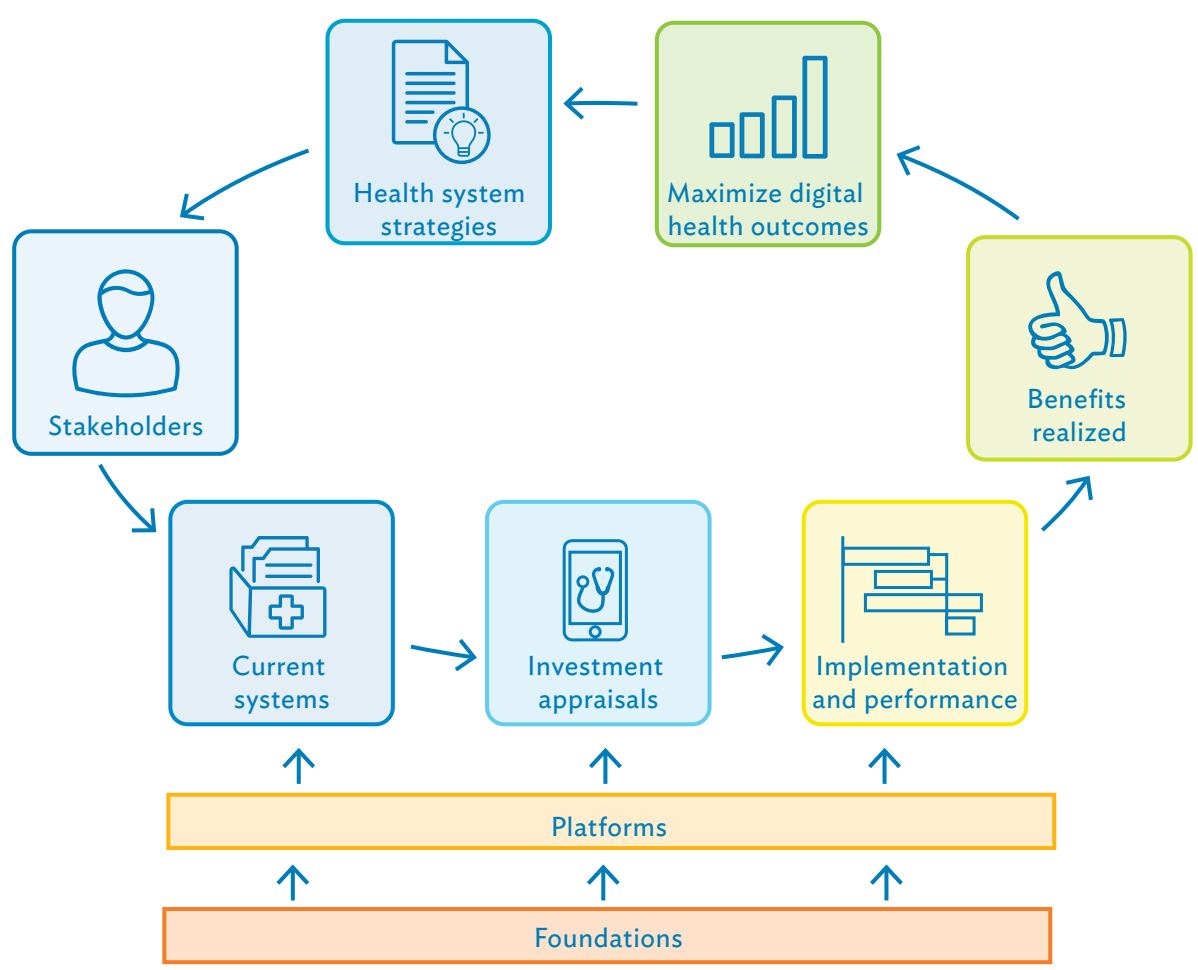




\section{KEY POINTS}

1. Leadership is key to establish and implement a digital health agenda.

2. Virtually all aspects of health are or will be supported by digital technologies. We, therefore, need appropriate investment in digital health, especially given the goals of universal health coverage (UHC) and integrated people-centered health services.

3. Meeting the Sustainable Development Goals (SDGs) requires better data management to achieve health targets (SDG 3), including UHC (SDG 3.8). Integrating siloed information systems offers greater access to data for research and clinical audit that, if well managed, can provide a marketable asset.

4. Governments should ensure that stakeholders make good investments in digital health, and that all investments enable the achievement of the SDGs and UHC.

5. Different stakeholders have different requirements for sharing and exchanging health information. To make such exchanges meaningful, we need agreed policies and standards.

6. Support interoperability with an agreed information architecture that describes how the health system operates, the standards to be used, and how data can be shared between agencies and meet users' needs.

7. Deploying digital health requires knowledge of local barriers to benefits realization and how to mitigate risks, like cybersecurity.

8. A proper understanding of the context and process for making digital health investments should help stakeholders make better decisions and defend the importance of durable, reusable digital health infrastructure.

9. Stakeholders in health include the population and individuals: the public (and those who happen to be patients), health workers who provide care (including the diagnostic and therapy teams) to people in primary and secondary care settings, managers of health organizations (clinic or hospital administration), payers, investors and donors, and planners and policymakers (including regulators and researchers). Each of them requires investments to help them meet their needs within the health system, and must be clear on what they want from investments.

10. Governments have particular responsibilities when it comes to investing in an enabling digital infrastructure, both technical and managerial. Building a strong case for these investments requires stakeholders to be ready and able to realize the benefits.

11. Most digital health investment decisions culminate in optimizing net socioeconomic benefits with financial affordability. Socioeconomic returns on investment (the difference between economic costs and benefits over time) give estimates of value for money. They are integrated with financial models that focus on affordability and return on investment (Appendix 2). 


\section{CONTEXT}

- Investments in digital health are increasing as countries improve their health care systems.

- Digital health systems lead to healthier populations, which can support inclusive economic growth.

- Relationships between health care, digital health, and improved productivity are complex. To understand them, we need more health data generated by digital health solutions, along with good governance to manage health information systems.

- To support digital health solutions with an enabling infrastructure, we need to address both digital health governance and technical issues that are appropriate for the country's context (health system, populations' health needs, and information technology maturity).

- The opportunities to leverage eGovernment investments, as well as to develop new digital health care models, should be taken as countries determine their strategies to support both universal health coverage and the Sustainable Development Goals with digital health.

\section{A. Development, Health, and Information and Communication Technology}

Developed countries have made significant investments in digital health. Since 2001, Canada has invested $\$ 2.15$ billion in its digital "Health Infoway" and achieved an estimated $\$ 16$ billion in benefits (quality, access, and productivity gains) from investments in telehealth, drug information systems, diagnostic imaging, and physician and ambulatory clinic electronic medical records (Green 2017). The Republic of Korea intends to increase investment in medical and health care sectors by more than $\$ 100$ million in the next 2 years, mostly in administrative simplification, claims adjustment/adjudication, and electronic health records (EHRs) (International Trade Administration 2016).

Continuing its long-term commitment to digital health, Denmark spent DKr2.1 billion (about 1\% of its health care spending) on eHealth in 2009, leading to annual savings between DKr330 million and DKr490 million. This provides a resource platform for future investment that includes clinical information and communication technology (ICT) workstations in all regions, supporting key work flows, a shared medication record, full digital communication between health care providers, more telemedicine, as well as the Fælles Sprog III common terminology project (Denmark 2013).

Digital health investments are booming too in the private sector. For example, in terms of connected medical devices for use at home and remote patient monitoring, the digital health market's revenue in Malaysia was $\$ 44$ million in 2017 , and is expected to grow annually by $19.5 \%$, reaching $\$ 75$ million in 2020 (Statista, 2017).

Health is a principal determinant of economic growth (Lopes-Casasnovas 2005). "Healthy populations are the foundation of sustainable economies" (World Economic Forum/Bain \& Co 2016) because healthy children miss fewer days of school and attend school for more years, setting them up to achieve higher levels of education. A healthier workforce is more productive, ${ }^{1}$ and generates higher returns for their employers and more steady tax revenues. Around one-quarter of economic growth between 2000 and 2011 in low- and middle-income countries is estimated to result from the value-improved health.

Productivity $=$ Output (gross domestic product) divided by the number of hours used to produce the output. 
The returns on investment in health can be as high as 9 to 1 (Report of the High-Level Commission on Health Employment and Economic Growth. 2016). ${ }^{2}$ Healthy workers also incur fewer costs for their employers and their respective health care systems. This is crucial to offset the economic cost caused by losses arising from absenteeism and early retirement due to ill health, which amount to about 6.5\% of gross domestic product for all countries (Rasmussen 2016). By living healthier lives, communities nurture "virtuous cycles of health"-recurring cycles of events, with the result of each one increasing the beneficial effect of the next-that fuel both health and growth. Healthy life years help drive continuous economic growth (Figure 1).

\section{Figure 1: Virtuous Cycle: Healthy Life Years for Continuous Economic Growth}

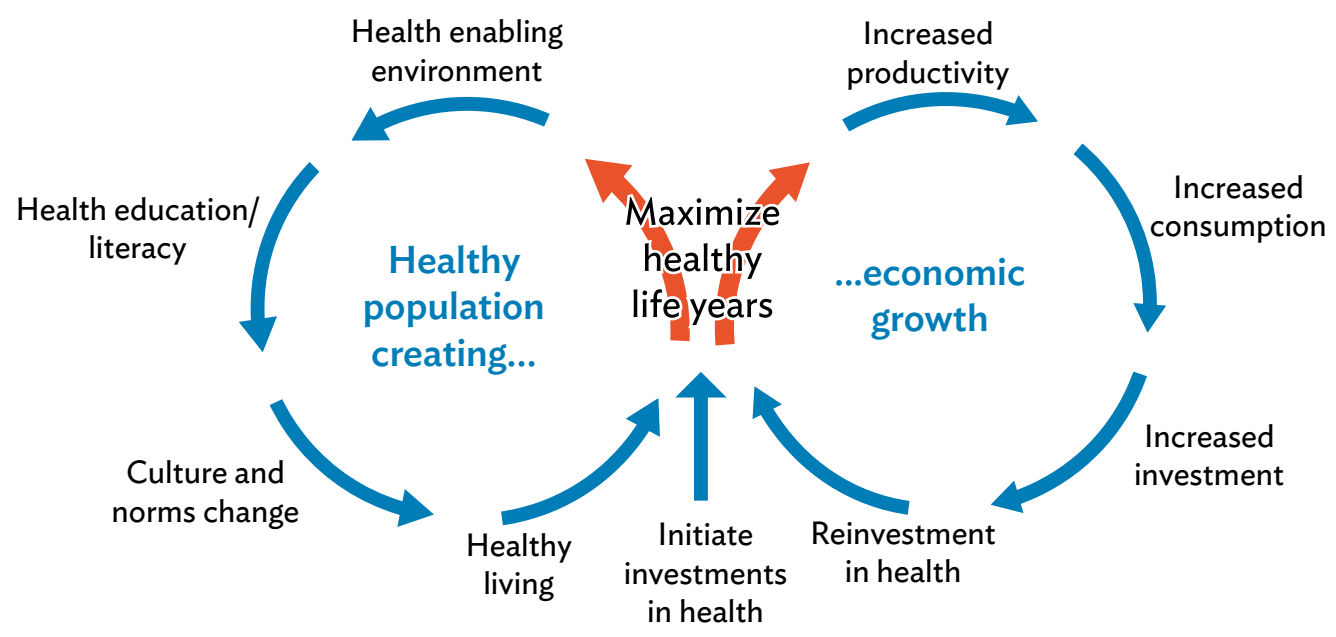

Source: World Economic Forum/Bain 2015.

Health systems have been described as "complex adaptive systems" (World Bank 2007). In other words, they can learn and change themselves, but those changes are not linear, nor easily predictable (The Health Foundation 2010). This makes it hard to be certain about the outcome attributed to any investment decision, other than by probability. Therefore, the approach should be to:

(i) understand the context, look for connections between the parts;

(ii) balance rules that (a) fix direction through strong leadership and vision; (b) set limits via regulations; and (c) provide permission (through incentives or resources);

(iii) understand how organizational structure influences behavior; and

(iv) use data to guide decisions. The best way to see how a health system is actually behaving is to constantly look at how it performs.

2 Eighteen countries were studied, including India, Indonesia, Japan, Malaysia, the Philippines, and Singapore. 
Improving the flow of information to guide decisions is key to support both health and development. As digital health becomes widespread, it's even more important to initiate good investments, and understand how those investments support the "virtuous cycle" of positive socioeconomic returns on investment and increasing healthy and productive life years by linking health to economic growth. But this growth should be ecologically sustainable amid the growing impact of climate change on human health (McMichael 2017). Indeed, this threat could undermine the last 50 years of gains in development and global health (Watts 2015).

Figure 2 illustrates how investment in digital solutions can support productivity, together with investments made in education and social protection. A healthier, more productive workforce also benefits other sectors, like public sector management, transport, and energy. But this needs to be supported by good eGovernance and eGovernment services. People then create social capital and economic growth through their work, taxes, and networks of shared norms, values, and understandings. That growth, as the Sustainable Development Goals (SDGs) recognize, must be inclusive.

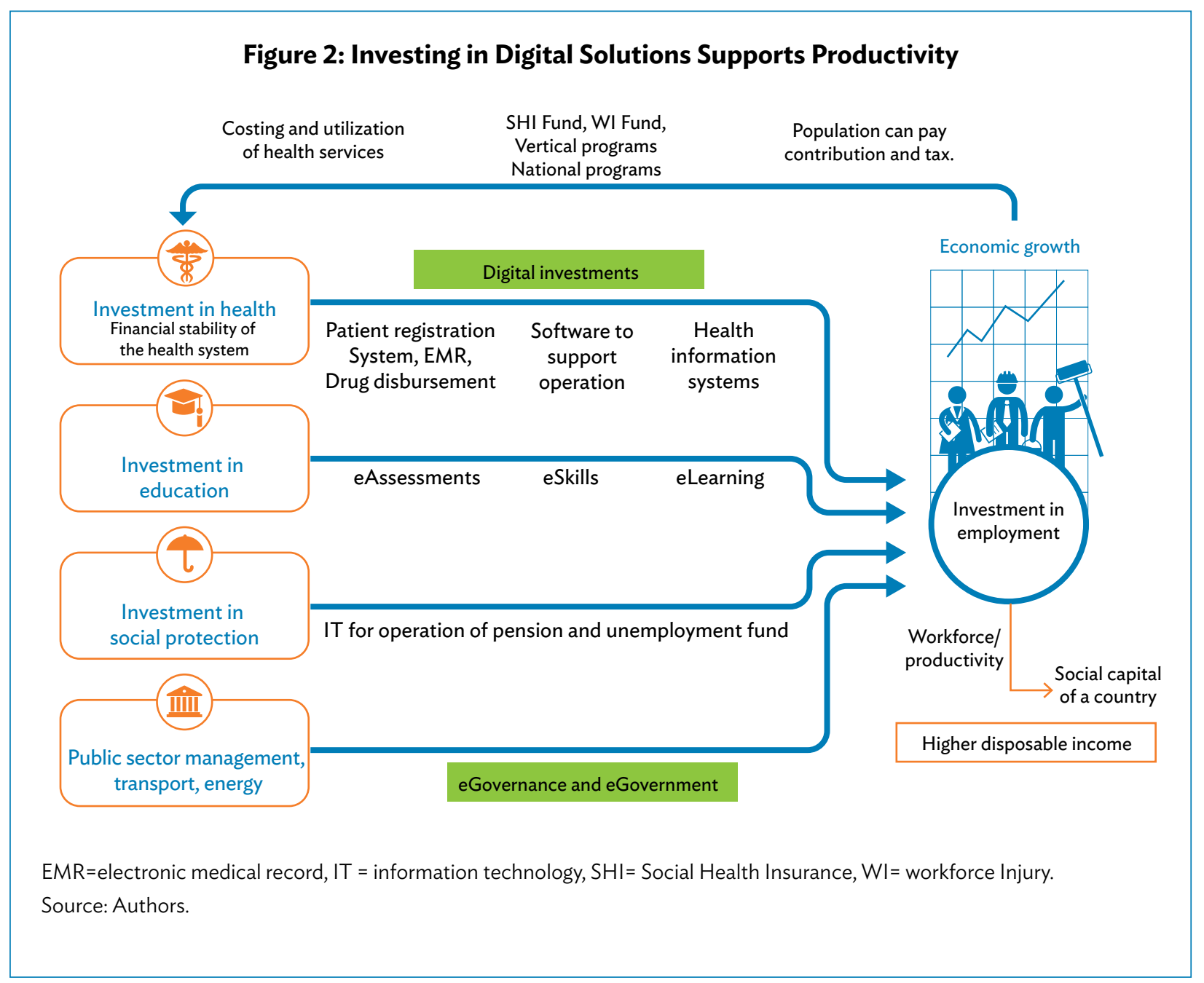

ICT needs to overcome a few barriers before it can play a key role in supporting sustainable development. The Global e-Sustainability Initiative (GeSI 2016) has grouped the barriers into three perspectives: political, industry, and customer (Table 1). We also offer some suggestions for potential government actions to address these barriers. 
Table 1: Potential Priorities for Infrastructure Development

\begin{tabular}{|c|c|c|}
\hline Perspective & Barrier to ICT Development & Potential Actions \\
\hline $\begin{array}{l}\text { "Rules of the Game" } \\
\text { (political) }\end{array}$ & $\begin{array}{l}\text { - Inadequate regulatory environment, and } \\
\text { unreliable application of regulations and } \\
\text { rule of law } \\
\text { - Lack of investment and financing incentive } \\
\text { - Limited awareness of ICTs potential among } \\
\text { stakeholders }\end{array}$ & $\begin{array}{l}\text { - Establish good eGovernance } \\
\text { - Use available financing options } \\
\text { - Generate awareness-raising material }\end{array}$ \\
\hline Supply (industry) & $\begin{array}{l}\text { - Lack of available capital for financing } \\
\text { - Lack of cross-sector collaboration/ } \\
\text { partnerships } \\
\text { - Lack of integrated standards across } \\
\text { technologies } \\
\text { - Lack of relevant physical infrastructure, e.g., } \\
\text { electricity, wireless spectrum }\end{array}$ & $\begin{array}{l}\text { - Seed fund start-ups } \\
\text { - Support an ICT supplier forum } \\
\text { - Support standards development and } \\
\text { Interoperability testing } \\
\text { - Strategic infrastructure investment }\end{array}$ \\
\hline Demand (customer) & $\begin{array}{l}\text { - Low affordability of ICT solutions } \\
\text { - Lack of acceptance of digital solutions } \\
\text { - Lack of applications in local language }\end{array}$ & $\begin{array}{l}\text { - Encourage assessments of value for money } \\
\text { and share knowledge } \\
\text { - Support change management } \\
\text { - Commission development and adaptation } \\
\text { of local content }\end{array}$ \\
\hline
\end{tabular}

ICT = information and communication technology.

Source: Global eSustainability Initiative 2016.

Governments can save costs by making careful investments in eGovernment services. For instance, it is a good idea to invest in technical and management foundations that support delivery and promotion. These strategies may include:

(i) one-stop, integrated platforms to access a range of public services, including health;

(ii) advanced search features that index content from dozens of government websites;

(iii) digital identity features that enable different systems to seamlessly exchange information; and

(iv) online tracking systems for citizens to check on the status of online transactions.

Integrating a range of online services and providing people with one-stop shops have helped some governments become more effective in delivering services in economic, social, or environment areas.

Good examples within the social area are in eEmployment, such as the Malaysian Electronic Labour Exchange, and digital ID management in Thailand. In health, the UN eGovernment Survey (United Nations Department of Economic and Social Affairs [UN DESA] 2016, p. 10) highlights the Webcam Connected Microscope (WebScope) developed by the Ministry of Public Health of Thailand to provide trusted telediagnosis and rapid treatment advice for the remote border provinces over a cloud-based network as an example of a whole government approach. Many eGovernment initiatives seek to expand participation as well as address some of the fundamental challenges of how best to stimulate consumer demand. One core infrastructure challenge is developing connectivity. The approach to building rural infrastructure can differ based on a country's degree of urbanization and wealth (adapted from World Economic Forum/Boston Consulting Group 2015, p. 17) (Figure 3).

European experience indicates that countries with larger populations may struggle to engage health professionals effectively, and integrate data when they rely on regional or provincial subsets (Stroetmann 2011).

Investments in digital health need to consider and leverage eGovernment initiatives, along with the opportunities offered by commitments to implementing eGovernment. For example, the Philippines has implemented a "Cloud-First Policy" (Integrated Government Philippine Program 2017) "to ensure 
Figure 3: Potential Priorities for Infrastructure Deployment

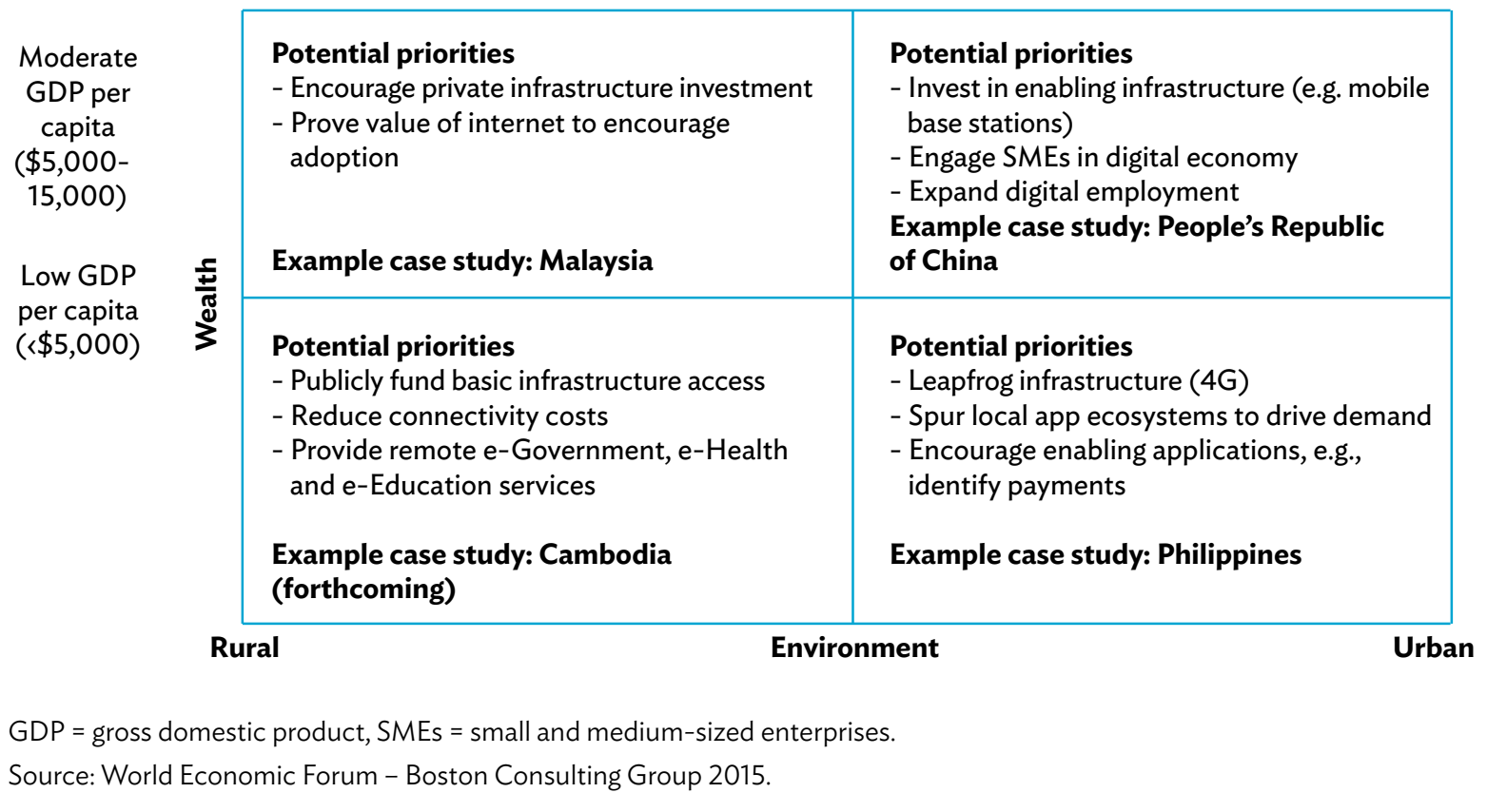

the provision of a strategic, reliable, cost-efficient and citizen-centric ICT infrastructure, systems and resources as instruments of good governance and global competitiveness". It expects "medical records such as personally identifiable education records, personally identifiable financial information, protected health information", which are recognized as "restricted sensitive data" to be stored on the Philippine GovCloud, an accredited public cloud with encryption requirements. When digital health projects require extra capacity and higher operational costs for these shared services, the outlay should be included as a resource for the project.

Lack of legacy systems, coupled with commitments to eGovernment and investment in infrastructure, creates opportunities for developing countries to "leapfrog" and develop lean policies and solutions based on lessons learned from developed countries. In this context, "with the internet and smartphone penetration growing and the technology infrastructure moving to cloud-based services, this presents the opportunity to develop innovative and cost-effective solutions to deliver health care services. These new digital health care models involve rapid prototyping, design and implementation which present great opportunities for emerging markets to leapfrog the developed markets" (PWC 2017, p. 5). But they also need strategic vision to frame the health system requirements together with the supporting foundations of both governance and technology to realize the value of the "digital dividend" of development (World Bank 2016).

\section{B. Sustainable Development Goals, Universal Health Coverage, and Digital Health}

Of the 17 SDGs, there are nine that contain targets relevant to health, but SDG 3 is primarily focused on health. Within SDG 3, target 3.8 is to achieve UHC (UN-DESA 2017). UHC ensures that all people obtain the health services they need without suffering financial hardship. Accordingly, "countries need to track progress not just across the national population but within different groups" like income level, sex, age, place of residence, migrant status, and ethnic origin (World Health Organization [WHO] 2014).

The SDG Agenda 2030 promises to "leave no one behind". As the director general of the WHO put it, "fundamental to achieving the SDGs will be the recognition that eradicating poverty and inequality, 
creating inclusive economic growth, preserving the planet and improving population health are not just linked but interdependent." (Chan 2015, p. III). Investments in meeting people's needs, data collection, and management to track progress should, therefore, reflect the shift toward the cross-sector paradigm, away from silo-based, vertical approaches (WHO/MA4Health 2015).

Under UHC, governments are encouraged to use national health insurance schemes to purchase care. Therefore, there is increased attention being paid to identifying who is receiving care for what condition. This requires linking digital health systems with civil registration systems and national identity management. Robust civil registration and vital statistics (CRVS) systems are crucial, as unregistered children may lack rights and access to services.

Another complementary policy framework, agreed at the World Health Assembly (WHA69/24 2016), is to strengthen people-centered health services. This means caring not only for patients but also for the health of people in their communities, and their role in shaping health policy and health services (Appendix 1). An integrated people-centered approach is crucial to build health systems that can respond to emerging and varied health challenges, including urbanization, the global tendency toward unhealthy lifestyles, aging populations, the dual disease burden of communicable and noncommunicable diseases, multiple morbidities, rising health care costs, disease outbreaks, and other health care crises.

The scope of digital health and the ecosystem of solutions is rapidly expanding. Digital health has been promoted as a tool to advance UHC. For example, it enables health systems to be more resilient by addressing inefficiencies (Roth 2015), achieving equitable access to affordable, quality health care for individuals and communities, and supporting improvements in primary health care. Digital health solutions help support integrated person- as well as people-centered services. Chapter $\vee$ also considers these issues. Digital health likewise requires:

(i) leadership to manage risks and realize benefits;

(ii) management, governance, and strategy; and

(iii) investments in backbone ICT infrastructure, architecture, policies, standards, and applications.

In addition, governments must understand where they should spend to lower the barriers that are preventing stakeholders from realizing the full benefits of their investments in digital health.

\section{Figure 4: Impact of Digital Health}

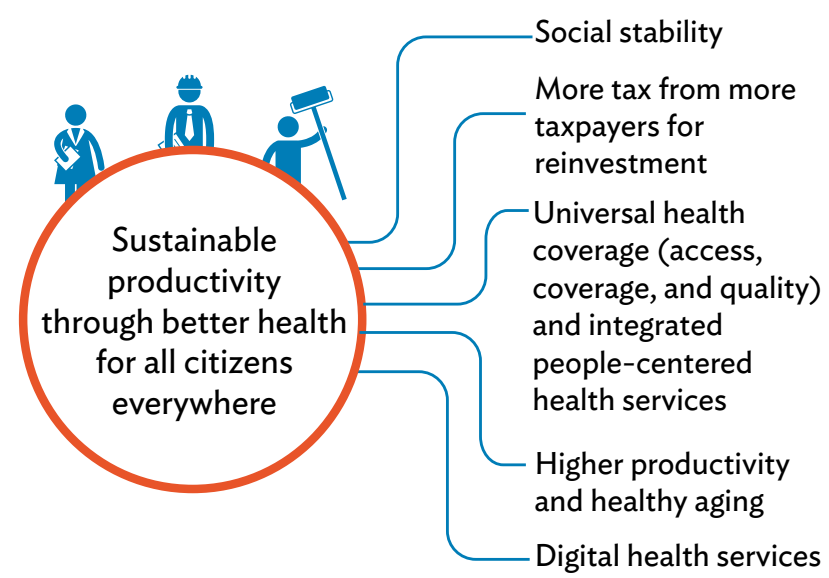




\section{SUPPORTING STAKEHOLDERS WITH STRATEGY AND ARCHITECTURE}

\section{A. Health Systems}

- Given the complex nature and objectives of different health systems that may exist in any country, understanding the requirements of all stakeholders is crucial.

- Digital health strategies must support the requirements of different stakeholders, while underpinning the solutions with well-designed governance, architecture, program management, and standards.

- The case for digital health is evolving, and new technologies will enable new ways of meeting stakeholders' requirements, such as to become less hierarchical and siloed and more patientand people-centered.

The complex nature of health systems is illustrated by the many actors that intervene to deliver health and health care to patients and the public.

Figure 5: Complex Web of Actors for Digital Health to Deliver Benefits
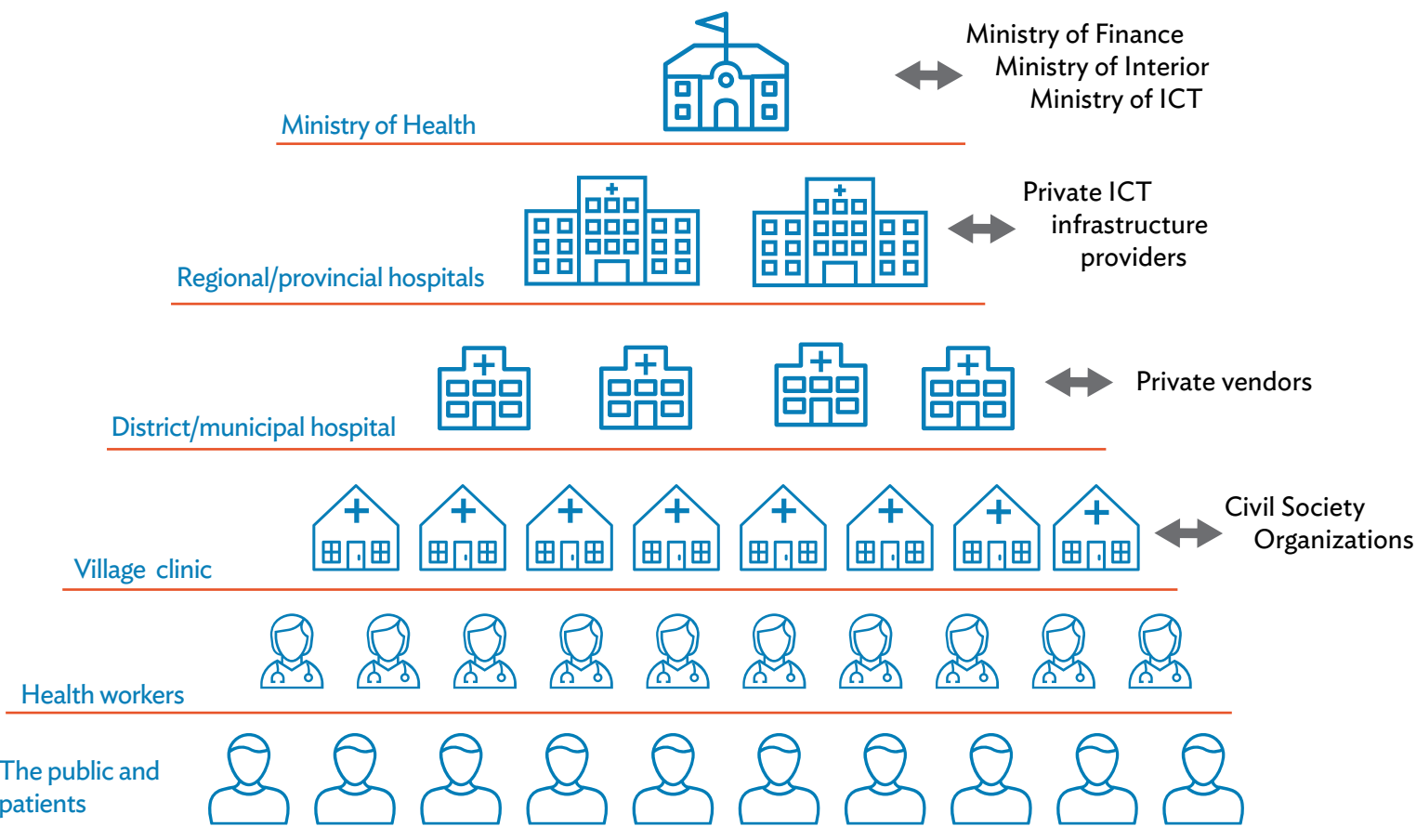

ICT = information and communication technology.

Source: Authors. 
There are different types of health systems, and their mix can vary considerably between countries. Government-funded public health care, the private health care sector, and health insurers often work in different areas (urban/rural; rich/poor). Donors, nongovernment organizations and faith-based organizations also take part in providing health care. But the objectives of these different providers vary. While profit may motivate the private sector, the goal of the public sector is to extend equitable and efficient health care. Synergies can be realized between both; for example, the public sector may view creating an enabling environment (such as ICT infrastructure) for the private sector as a cost-effective way of encouraging coverage. Much of this depends on local and national contexts.

\section{B. Stakeholders}

There are many stakeholders who are involved in health systems of any sort:

(i) the public, including citizens, communities, and patients;

(ii) health workers who deliver care directly to patients, or indirectly by providing diagnostic or therapeutic support;

(iii) managers of health and health care organizations who are concerned with enabling health workers to do their work, whether this is in a community setting, or a hospital; this covers managing district and regional services, including promoting population health;

(iv) payers such as insurance carriers, other third-party payers, or health plan sponsors;

(v) investors and donors; and

(vi) government planners and policy-makers.

It is challenging to align the digital health infrastructure that is required by all these stakeholders to deliver health care services, especially to provide insurance coverage. Figure 6 illustrates the key supporting systems.

\section{Figure 6: Health Insurance System and eGovernment Connected by Interoperable Digital Systems}

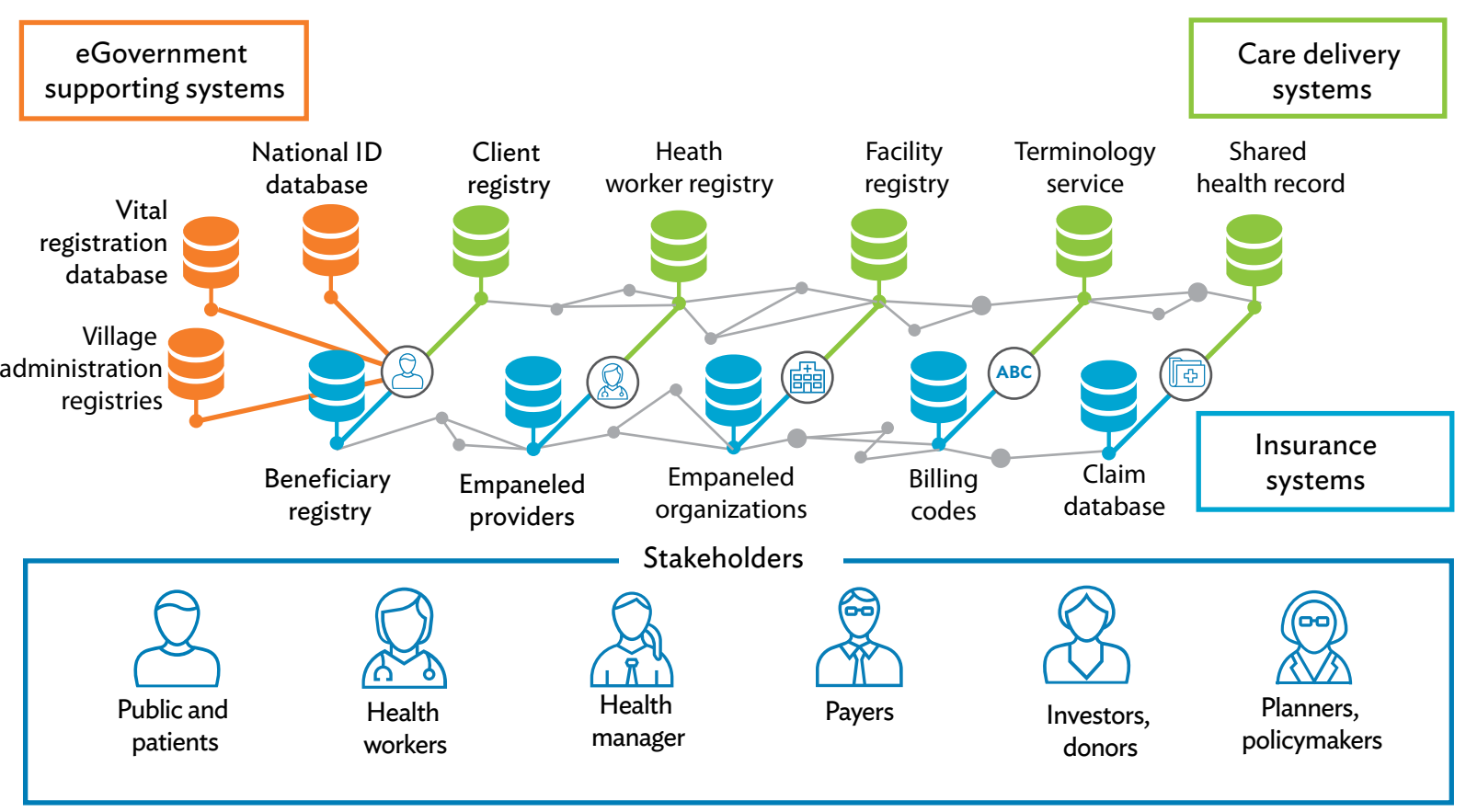

ID = identify.

Source: Authors. 
Key stakeholders need digital applications that meet their requirements, such as to get or provide clinical advice, make or receive payments, and gather information for planning and policy making.

Although single-user, stand-alone, and single-purpose solutions characterized the early days of ICT, a complex health system should be considered as an "enterprise" with back-end solutions to support the service provider. However, for this more holistic approach to work, there needs to be a structured way to understand what the requirements of key stakeholders are before making investments to meet them.

\section{Strategy}

The WHO and International Telecommunications Union (ITU) produced a toolkit (WHO/ITU 2012) to help governments improve eHealth or digital health (without giving explicit guidance on making business or investment cases) by describing the key components required for

(i) leadership and governance (to identify the preferred leadership and governance model, including defining the relationship to existing bodies at national, state, and local levels);

(ii) strategy and investment (to produce a description of the eHealth strategy and investment components required to support the development and operation of the national eHealth environment);

(iii) services and applications (to produce a description of eHealth service and application components required to deliver eHealth outcomes described by the initial eHealth vision);

(iv) infrastructure (to produce a description of eHealth infrastructure components required to support eHealth service and application components identified);

(v) standards and interoperability (to support eHealth service and application, and eHealth infrastructure components identified, as well as broader changes to health information flows required to deliver eHealth outcomes described in the initial eHealth vision);

(vi) legislation, policy, and compliance (to produce a description of eHealth legislation, policy, and compliance components required to develop and operate the national eHealth environment); and

(vii) workforce (to produce a description of eHealth workforce components required to develop, operate, and support the national eHealth environment).

Figure 7: Stakeholders Benefit from Well-Defined eHealth/Digital Health Strategy

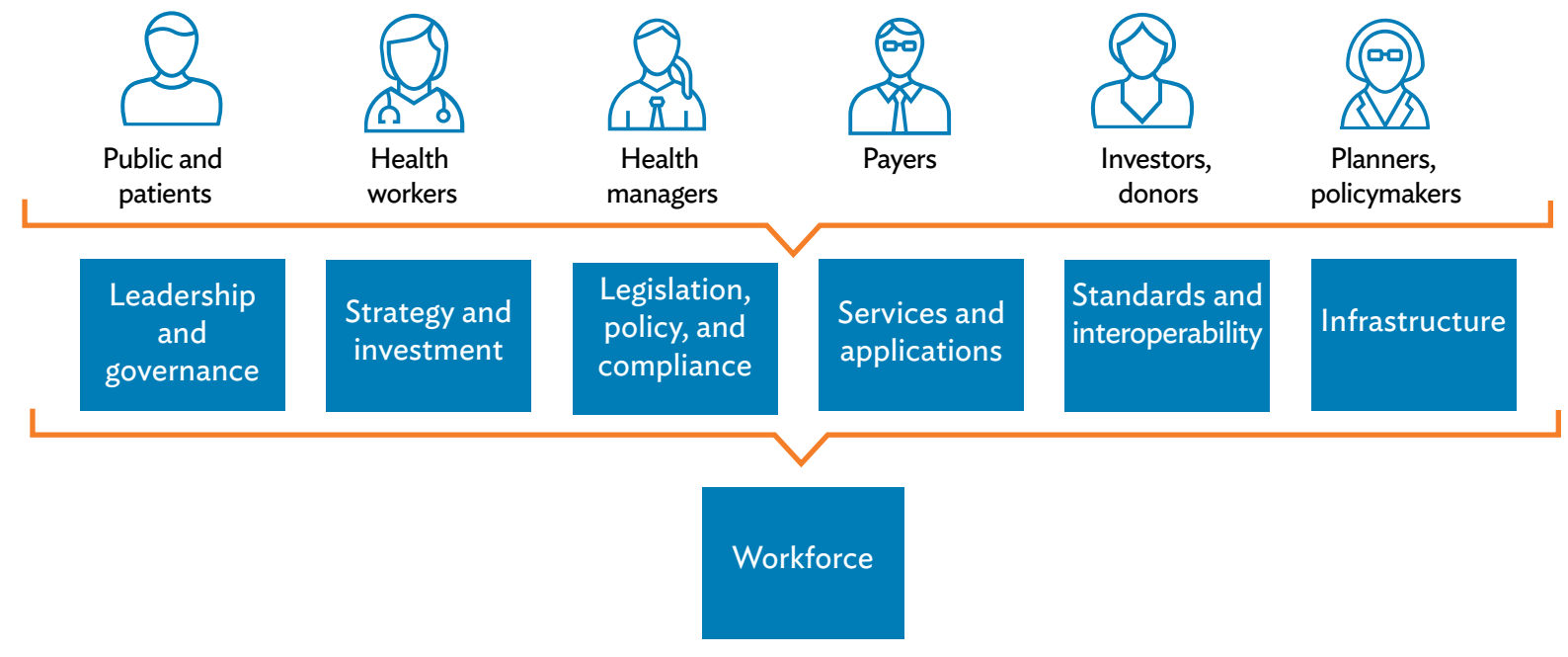

Source: Authors. 
Country experience suggests that, while digital readiness can vary, the investment required generally falls into four broad groups:

(i) Foundations. This refers to eHealth components that secure national information exchange and/ or are more cost-effective, if done once at a national level.

(ii) Solutions. Find eHealth components that access, interact with, and use national foundations and infrastructure to access and share information.

(iii) Change and adoption. Motivate and support the health system, establish incentives, and identify changes needed in work practices.

(iv) Governance. Coordination, visibility, structures, and mechanisms for accountability and effective leadership.

\section{Architecture}

Experience has increasingly shown that health information architecture is essential for a health enterprise. It is not about a single system or process that meets the requirements of a specific sponsor, but rather on the entire enterprise-and the processes and information flow within it-that can advance the overall strategic vision.

Implementation evidence demonstrates that many foundation investments made by governments become shared digital assets, and provide benefits for all. This makes it difficult for the private sector to provide these sorts of services, which include:

(i) National authentication service for identity management. In Thailand, this service began in 1982 with the objective that every citizen has only one ID number from birth to death, both for reference and verification.

(ii) CRVS. Register all births and deaths, including causes, as well as marriages and divorces. Birth and death certificates are issued, and statistics compiled and disseminated.

(iii) Unique patient identifiers, and the registers to support them.

\section{Box 1: Thailand Identity Management}

In Thailand, by law, the National Civil Registration Office, Ministry of Interior is responsible for registering all births, deaths, marriages, divorces, and migrations. A unique 13-digit ID number is generated for each Thai citizen whose birth is registered in the national civil registration database. National ID cards are issued to citizens when they turn 7. The national ID is used, for example, in school enrollment, civic services, police services, and housing. Private organizations and companies also use it to uniquely identify individuals when doing business with them (banking, telecommunication services). Thailand's health care system uses national (citizen) ID to identify individuals and support universal health coverage, although each health care provider (organization, hospital) usually has its individual local IDs (hospital number for patient) for its information system. The local IDs are mapped with the national IDs. Close collaboration between the National Health Security Office and the Ministry of Interior has resulted in improvements in Thailand's births and deaths registration system.

Source: Ralf Hundertmark. Advanced Information Technology Public Co. Ltd. Bangkok (personal communication).

While these investments cross over with eGovernment programs, those relating directly to the health sector include:

(i) registries and data storage for patients, facilities, and health workers;

(ii) clinical terms and coding; 
(iii) data sets for clinical and management purposes;

(iv) messaging standards;

(v) software compliance and accreditation;

(vi) interoperability selection and testing;

(vii) data warehouse, cloud storage, health information exchanges (HIEs); and

(viii) cybersecurity.

Notable industry investments from standards development organizations include coding, terminology, and messaging guidelines and standards (e.g., Systematized Nomenclature of Medicine--Clinical Terms [SNOMED CT], International Classification of Diseases 10th Revision [ICD-10], Logical Observation Identifiers Names and Codes [LOINC], and Health Level 7 [HL7]); and integrating health care enterprise profiles (IHE). Industry standards must be adapted to the local context for appropriate use.

These "horizontal" programs create the conditions in which disease-specific programs and patientcentric care can be delivered more effectively. For example, digital health records for one disease program for an individual should be capable of integration (via use of the above standards) with other health data in a shared personal record that can be exchanged with other health care providers, as well as held by the individual. This means that, for those with complex and/or chronic conditions and under the care of different providers, the information shared about the care provided should be seamless, and help that care to be more effective. The health information "exchange" of digital health records is mediated via a network, which is another public good for governments to invest in.

Public investment enterprise-wide approaches to digital health are clearly necessary, but that money can go to waste if the perspectives of key stakeholders are ignored. They are making digital health investment decisions of their own on whether to purchase a patient administration system for a hospital, or investing in low-cost sensor technology to support data-driven decision-making at clinic level. This is why digital health governance is so important to support investment decisions and give guidance on questions such as whether health workers may use personal mobile phones at and for work (the bring your own device model). Similarly, citizens can decide to invest in smartphones to access relevant and engaging health information. Stakeholder requirements must be part of making the case for investing in digital health.

In short, governance, architecture, and standards are all needed, as well as good program management to ensure delivery (Asian Development Bank [ADB] 2018).

The case for digital health is always evolving. Value for money (VFM) is constantly rising, which raises the issue of the cost of obsolescence. That is why making the case for an investment must be in the context of the overall strategy for health, health care, and development in any given country. The traditional response to the changing pressures of demography, social and ecological determinants of health, and rising expectations of people and patients has been to manage the existing top-down bureaucratic processes and information flow better. Now, however, opportunities are emerging to support the transformation of health and health care services so that they can deliver integrated people- and personcentered care to everyone everywhere. This recognizes that citizens are becoming increasingly engaged participants in the process (Schmidt 2015).

We must scale up attention and investments in digital health architecture, governance, and standards because digital health systems are becoming more complex, less hierarchical, and more distributed centered on the patient. There are new and more flexible digital technologies emerging that can be directed to support these transformational objectives that encourage better-informed interactions between all stakeholders. This context is a continuing cycle of change, yet also one of the opportunities 
to transform the way health systems can improve the delivery of health and health care. Deciding on the principles that will guide the evolution of health systems (pursuit of UHC, with integrated patient- and people-centered care, to meet the SDGs) and how technology can then best support this is further addressed in Chapter V.

There are questions that can help guide and structure this process of change, and also provide information and incentives that encourage stakeholders to make sound investment decisions.

Figure 8: From Managing Health Organizations to Enabling Informed Stakeholders

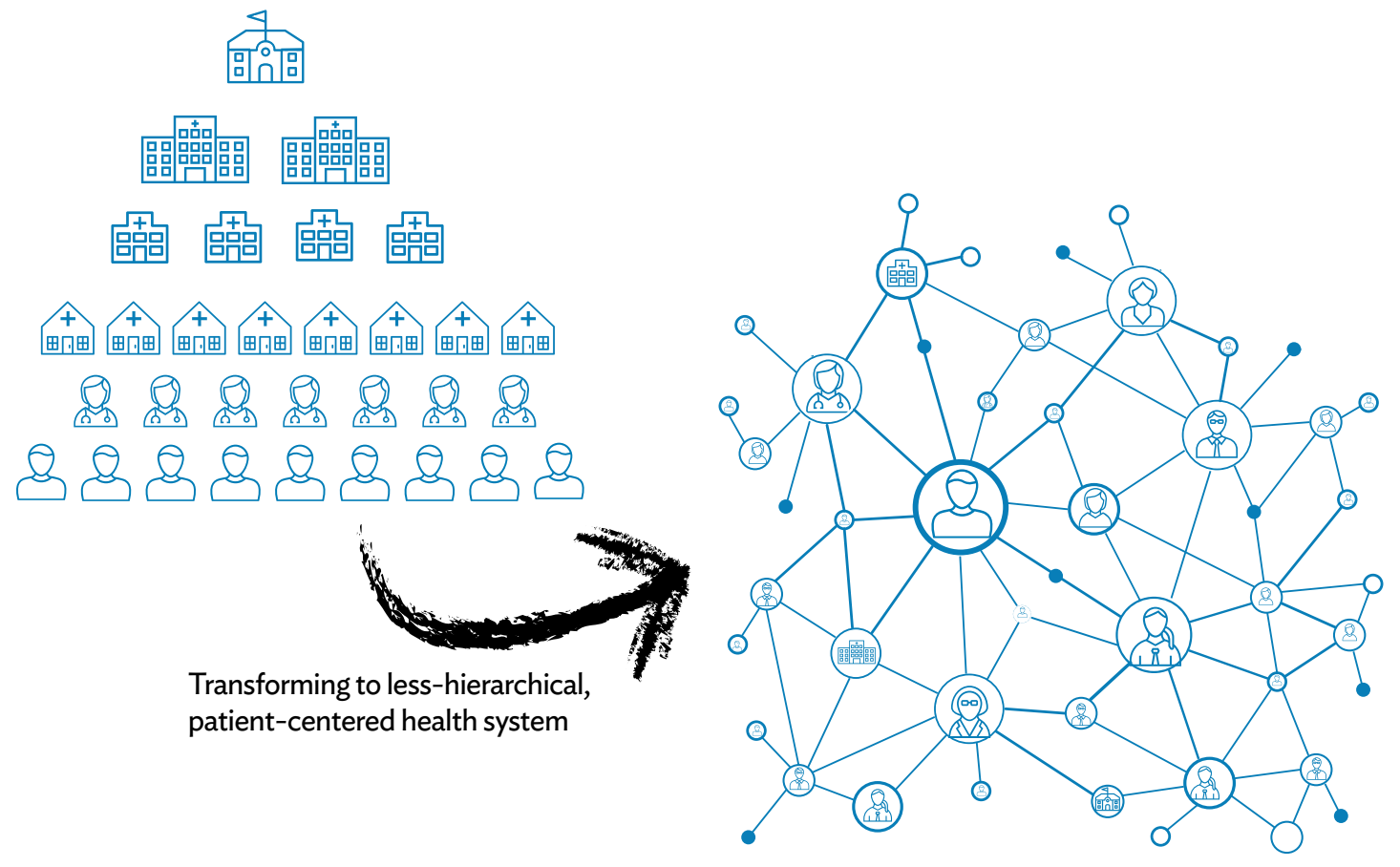




\section{STAKEHOLDERS, AND THE CYCLE OF CHANGE FOR MAKING DIGITAL HEALTH INVESTMENTS}

- Supporting health systems with digital health is a dynamic process of change to use data for better-informed decisions. This requires a cycle of continuous questioning of the status quo, the benefits intended, how results are valued, and how benefits are realized.

- Each of the six key stakeholder groups has key concerns and requirements for digital health. Understanding them in a country-specific context, along with what government investment can do to address them, helps frame the digital health investment process.

\section{A. Cycle of Change}

At the hub of the cycle of change are the processes of nurturing a data use culture (Government of Tanzania/Programme for Appropriate Technology in Health [PATH] 2017) and enabling better information to inform decisions. In an increasingly connected health system, it is critical to produce not more data, but the right data to improve peoples' health. This requires developing and updating a strategy for digital health that supports the national health strategy, and guides investment and implementation.

Figure 9: Cycle of Change for Making Investments in Digital Health

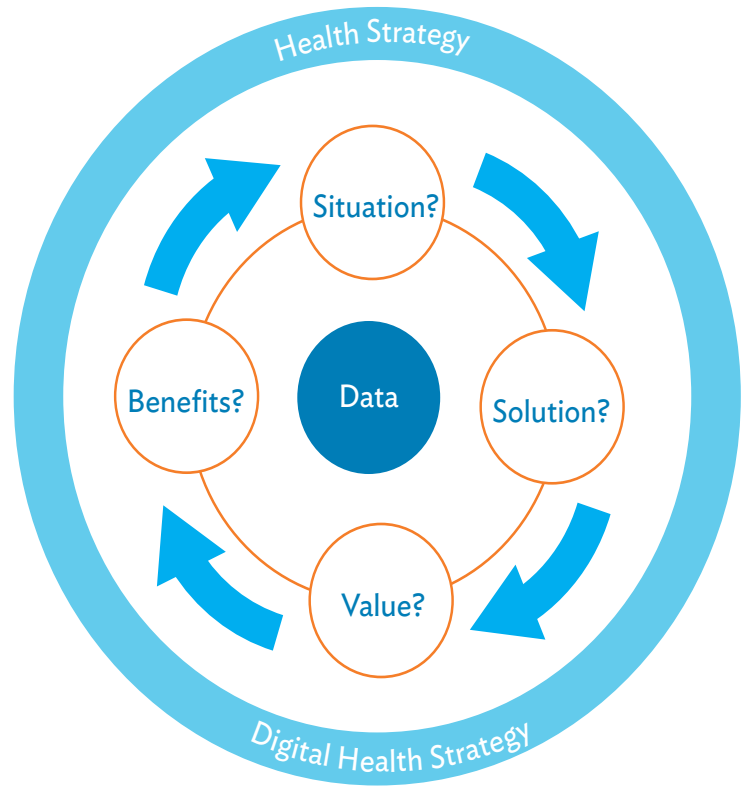


In summary, in any given process of deciding how best to invest in digital health, there are four key questions (Appendix 2).

\section{What is the status quo? Which of the following are of particular relevance?}

\section{Context}

(i) Policy environment: global-local, fragile or stable (Messner 2017), income and development status (World Bank 2017), pressures for change, e-governance plans in place.

(ii) Determinants of (ill) health: social, economic, environment, behavior, genetics.

(iii) Health issue(s) of concern: epidemics, disasters, acute or chronic care.

(iv) Geography: demography, rural versus urban, physical geography, climate, borders.

(v) Technology: power, networks, storage, skills, digital maturity.

\section{Health Systems}

(i) Provider and payer: public versus private, donor, faith, complementary.

(ii) Level in focus: population, community, home, practitioner, health post or center, hospital, district or region.

(iii) Progress toward UHC.

(iv) Human capacity and capability.

\section{Stakeholders}

(i) The public, including citizens, communities, and patients.

(ii) Health workers that deliver care directly to patients, or indirectly by providing diagnostic or therapeutic support.

(iii) Managers of health and health care organizations who are concerned with enabling health workers to do their work, whether this is in a community setting, or a hospital. This covers managing district and regional services, including promoting population health.

(iv) Payers such as insurance carriers, other third-party payers, or health plan sponsors.

(v) Investors and donors.

(vi) Government planners and policy-makers.

\section{Digital Health Solutions}

(i) What backbone ICT infrastructure investments are needed? What are the technologies (mobile phones, communication networks, storage solutions) required to deliver them?

(ii) What are the services and applications that meet the users' requirements?

(iii) What standards (identifiers, linkages to non-health systems, CRVS, and national ID systems) are needed to make the systems interoperable?

(iv) Are the proper leadership, governance, and technical standards in place?

(v) What is the current enterprise architecture?

(vi) What do clinical decision-makers need?

(vii) What is the regulatory environment on privacy, security, or use of open-source solutions?

(viii) Can the private sector become the ICT solution provider and/or manage private health organizations? 


\section{What digital health solution is proposed, and what benefits and investments are intended?}

Given the situation assessment, what pathway can realize the benefits of an investment in digital solutions?

(i) What are the investment options for each digital health project?

(ii) What inputs, processes, outputs, and health and health care outcomes are expected? Looking for key bottlenecks will help identify where potential interventions and investments may be most needed. Toolkits are available to test different scenarios (some are in Appendix 3).

(iii) What are the estimated socioeconomic returns, the financial returns on investment and its affordability, and how long will it take to achieve them?

(iv) What are the estimates of parameters such as improvements in operational efficiency, reduction in time consumption, cost savings, and quality improvements (LeFevre et al. 2017)?

(v) What are the potential sources and amounts of capital and operational finance?

(vi) Will the intended solution be sustainably affordable?

(vii) How can risks be mitigated?

\section{How and by whom are results valued?}

(i) Which interventions are "public good" investments?

(ii) Which interventions do the public value?

(iii) Which investments require coordination with other sectors and ministries?

(iv) Does the planned intervention help all relevant stakeholders make informed decisions with the data and analytical tools at their disposal? Is more knowledge available?

(v) How will the socioeconomic benefits be estimated and assessed?

(vi) Have the opportunities for reducing costs, improving quality, access, equity, and increasing efficiency been realized (Appendix 4)?

(vii) Has the value of clinical and social outcomes been fully considered (Schweitzer 2012)?

(viii) Have the risk assessments been fully made, and sensitivity/optimism bias analyses conducted?

(ix) What are the expected outcomes for the costs of existing digital (or non-digital) systems over time?

(x) What are the VFM estimates assessments and projections over time?

(xi) What will be the key performance indicators?

\section{How will benefits be realized?}

(i) How will costs be controlled and benefits realized?

(ii) Will digital health investments that support the health sector also benefit the development of a community?

(iii) What will be the impact on the ecosystem of suppliers of relevant digital health solutions?

(iv) What changes will be required if expected benefits are not delivered (Peppard 2016)?

(v) What monitoring and evaluation (M\&E) actions can ensure that benefits are realized, assessed, and lessons learned (WHO 2016)?

To answer the questions above, we need to understand why investing in digital health makes sense to key stakeholders, and what their requirements are. Of course, requirements for the future are strongly influenced by experience of current systems. For example, what has been their experience (or that of their peers) on payer information systems, medical devices, social media, electronic medical records, diagnostic support systems, and registers? Perceptions of how well solutions are working need to be 
calibrated against the socioeconomic benefits they are delivering, and to whom. If the current information and digital health system are not well supported by available ICT platforms and applications, perhaps because the basic infrastructure and registries are not in place, then this will impact perceptions and requirements.

Appendix 4 illustrates some of the key issues for patients, and for planning, management, and administration. It suggests potential areas for saving costs and increasing benefits, and indicates some of the basic infrastructure and registries that may be needed.

A high-level illustrative summary of some of the issues on digital health for each of the key stakeholders follows. It is structured around the following:

(i) Key questions: What are the main opportunities and top-of-mind concerns?

(ii) Requirements: What sorts of solutions will be required to meet them?

(iii) Potential areas for government investment: What issues should the government consider before investing?

\section{B. The Public (and Patients)}

Increasing attention is being paid to understanding the role and information requirements of people in communities in shaping health policy and health services (see integrated people-centered care, Appendix 1).

\section{Figure 10: Public and Patients: Key Questions and Requirements}

Questions

Requirements
What do I need to know to provide the right care to my communities/ patients?

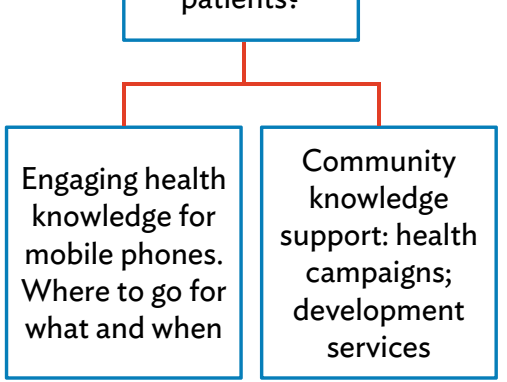

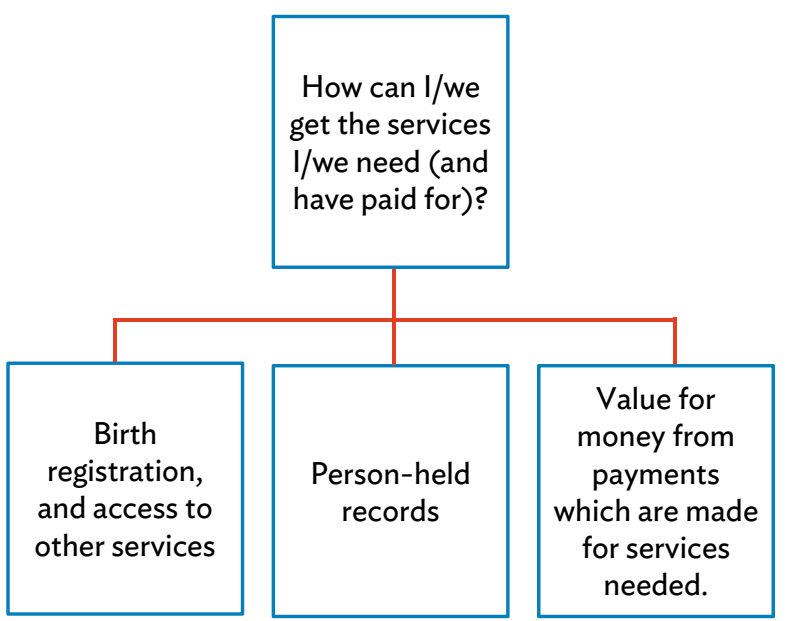


Citizens, family caregivers, communities, and patients should all be able to easily access information about what they need to know or do to make a good choice about their health. This requires the following:

(i) Engage attention (use audiovisual tools and appropriate language, watch out for cultural context), and make sure information is accurate and does no harm.

(ii) Leverage technology that people already have, such as mobile phones, for instance by sending advice or reminders (Rajan et al. 2013). Improve health apps for digital health, like providing information on where to go, given certain symptoms.

(iii) Communities can benefit from investment in health knowledge via commissioned TV programs, and health campaigns through mobile screening.

(iv) Make birth registration essential to access and receive health services.

(v) Empower patients to know about where they can access care, what standards of care they can expect, and to enable them (if they wish) to hold records on what kind of care has been received.

(vi) Help patients know what the out-of-pockets costs and insurance coverage will be, so they can judge whether the health service delivers VFM.

Government investment in content management, with user-friendly access to content that is provided (by them, international development partners, or locally produced), offers the return of healthy lifestyles and behaviors that improve productivity and help prepare for old age. This should be part of certifying or regulating health apps.

A citizen's identity enables them to use health services and to have a record made of this interaction, though arrangements vary between countries for visitors and immigrants. Core to identification (both for health and other services) is birth registration data. When health data is recorded about an identifiable individual, this person should have access to it via paper, phone, or other secure digital methods (Alabbasi 2015). A verified identity facilitates payments.

Government investment should provide training on (digital) birth registration; ID, agreed standards for person-held records; and governance and clinical audit to ensure that the providers give VFM.

Additional benefits can come from a content management platform to include appropriate localized knowledge for implementing the other SDGs, and having a strengthened CRVS system.

\section{Health Workers (including Doctors, Nurses, Pharmacists, and Diagnostic Teams)}

Health workers include all those who deliver face-to-face care to people, including community health workers, doctors, nurses, and paramedical staff. They also cover professionals that provide diagnostic and therapeutic support.

Health workers require quality and localized knowledge support to be available at the point of care (POC) to help them make good decisions on diagnosis and care options.

Health workers are already investing in purchasing their own devices, and may expect to be reimbursed with credit for the health system-related messages they send. In addition, they need apps and services to order supplies like drugs, and this functionality should have a consistent and user-friendly interface. This may require a dedicated handset, particularly if patient record applications are involved. However, once medical records are available, then decisions can be based on already recorded data, such as allergies or medical history. This improves the quality of care. 


\section{Figure 11: Health Workers: Key Questions and Requirements}
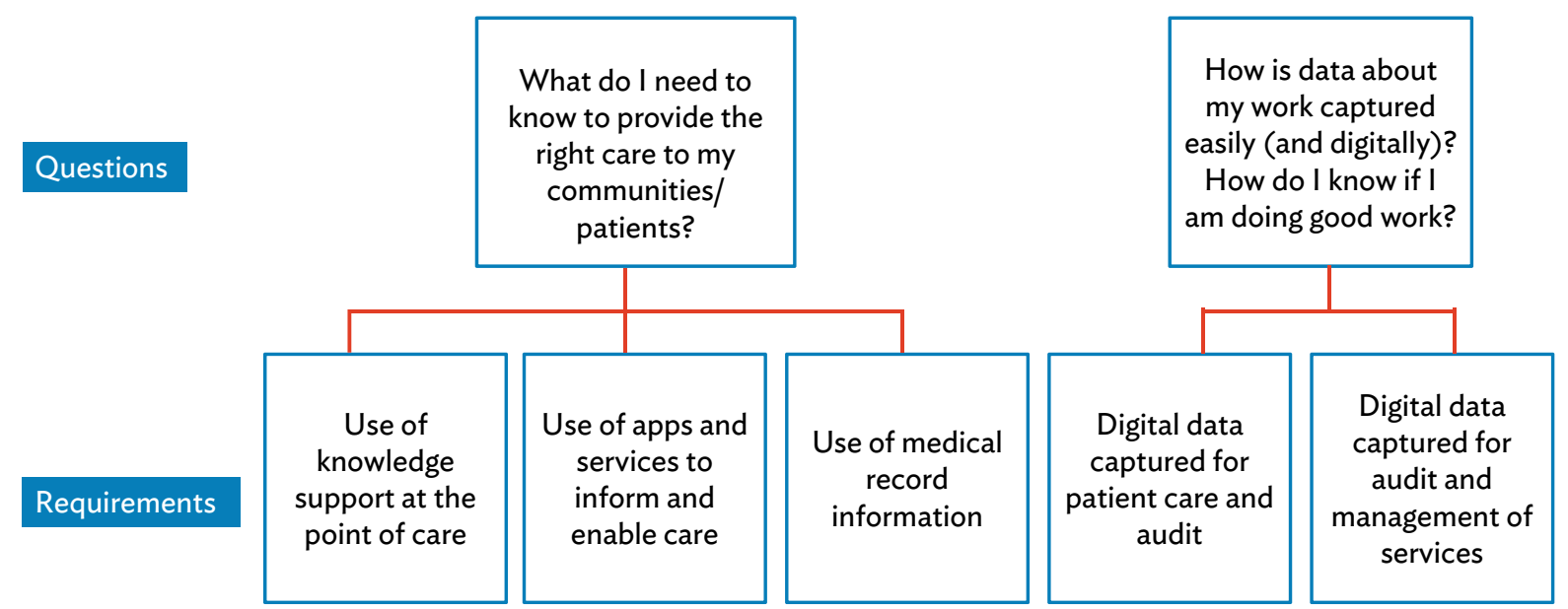

Source: Authors.

Government should invest in sourcing good quality content; for instance, through commercial agreements with the private sector. Investment is also needed to provide (power and) connectivity for health workers, and an easy-to-use interface to other services that they need, such as a stock control system. Governance (and cybersecurity implications) of the bring your own device model must be addressed.

There are many siloed solutions to support health workers, often provided by different donors (McCann 2012). The range of forms required of health workers needs to be rationalized, and digitized. For example, a study in Ghana (Tarr et al. 2014) found that community-based health workers managed 15-24 separate registers to document services to their clients. In Swaziland, it is estimated that for every hour of patient care, a health worker spends 20 minutes managing data for immunization care, or 42 minutes for HIV/AIDS care (United States Agency for International Development [USAID], Systems for Improved Access to Pharmaceuticals and Services [SIAPS], and Village Reach 2015). The example from Nepal shows that health workers have no incentives to digitalize health information in the current model, undermining digital health investment benefits (Box 2).

Digital health solutions should provide health workers with more time for patient care. Management information about service provision and billing should be a by-product and not the objective for digitalization.

\section{Box 2: Nepal: Taking Stock of Health Workers' Record Keeping}

Health workers:

- capture data in their information and communication technology system mainly for reporting purposes (to the government or donor),

- do not have significant advantages in their daily work routine from entering the data,

- digitalize data while still filling out long and complicated forms, and need extra room for hard copy files, and

- have very little incentive to enter data into available information and communication technology systems.

Source: Michael Stahl. 2016. Scoping Assignment for Establishing Unique Health ID in Nepal. Mission Report. Sweta Khanal, GIZ (April). 
Figure 12 shows how knowledge support and care guidelines inform health workers to make good decisions and support care continuity wherever care is being provided. The process creates transactional data for management information. Based on this information, we can improve the management assessment of a health service for a given population, and develop standard procedures for delivering care.

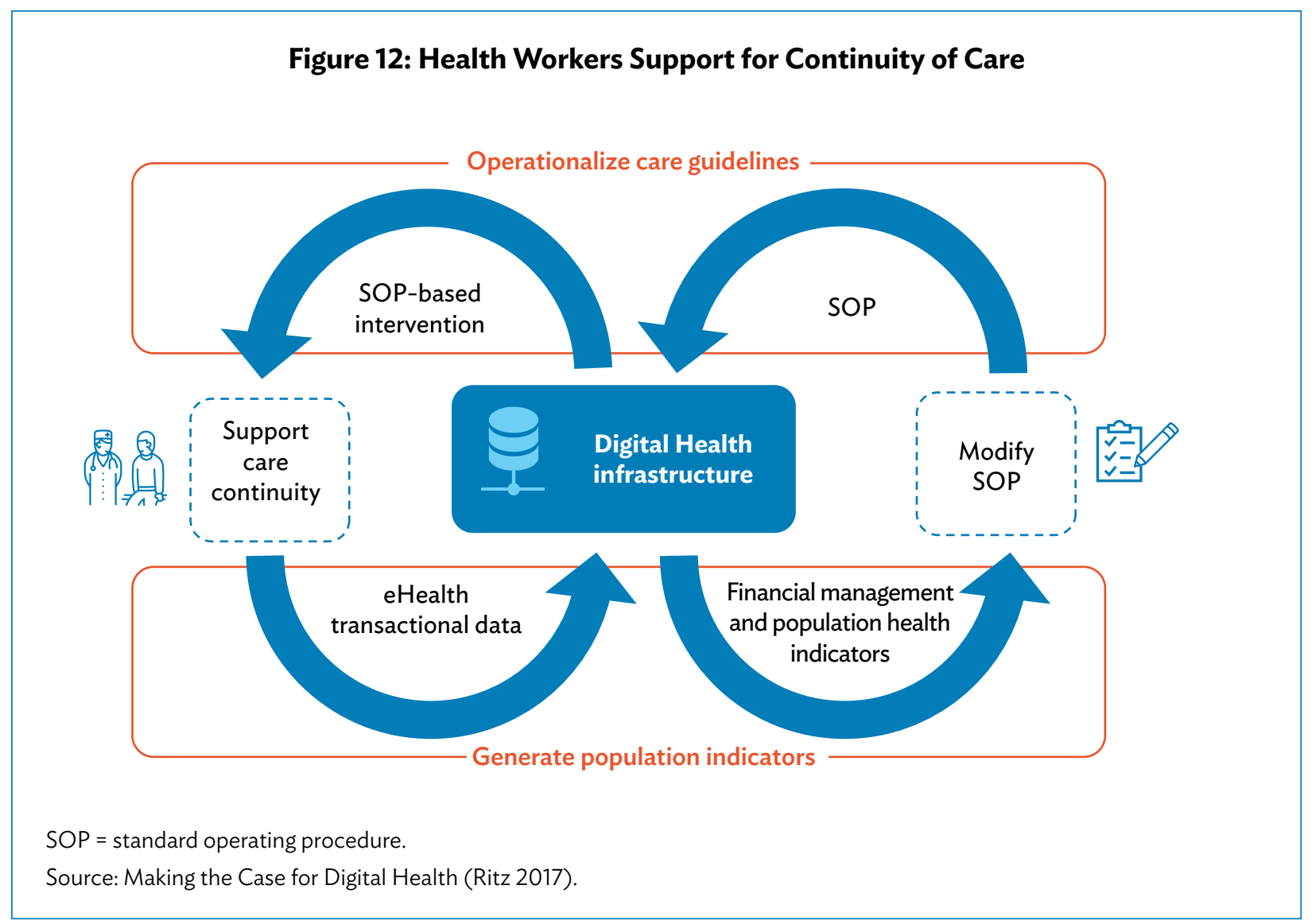

Government should also invest in the technical and management arrangements for common, consistent (and user-friendly) digital health interface standards. Open-source solutions are available, but are not cost-free.

Additional benefits can be derived from building on knowledge support foundations to support training, and continuing professional development and assessment wherever health workers are based. Empowered health workers can share their ideas and innovations so that peer group and learning behaviors improve, thereby improving the socioeconomic returns.

\section{Health Managers}

For those responsible for the management of hospitals and clinics, the primary task is to provide what health workers need to deliver the right services to the right people with equity, efficiency, and economy. For those responsible for assessing the health needs of the population and encouraging healthy behaviors, good data (of different sorts) should guide priority-setting. 


\section{Figure 13: Health Managers: Key Questions and Requirements}

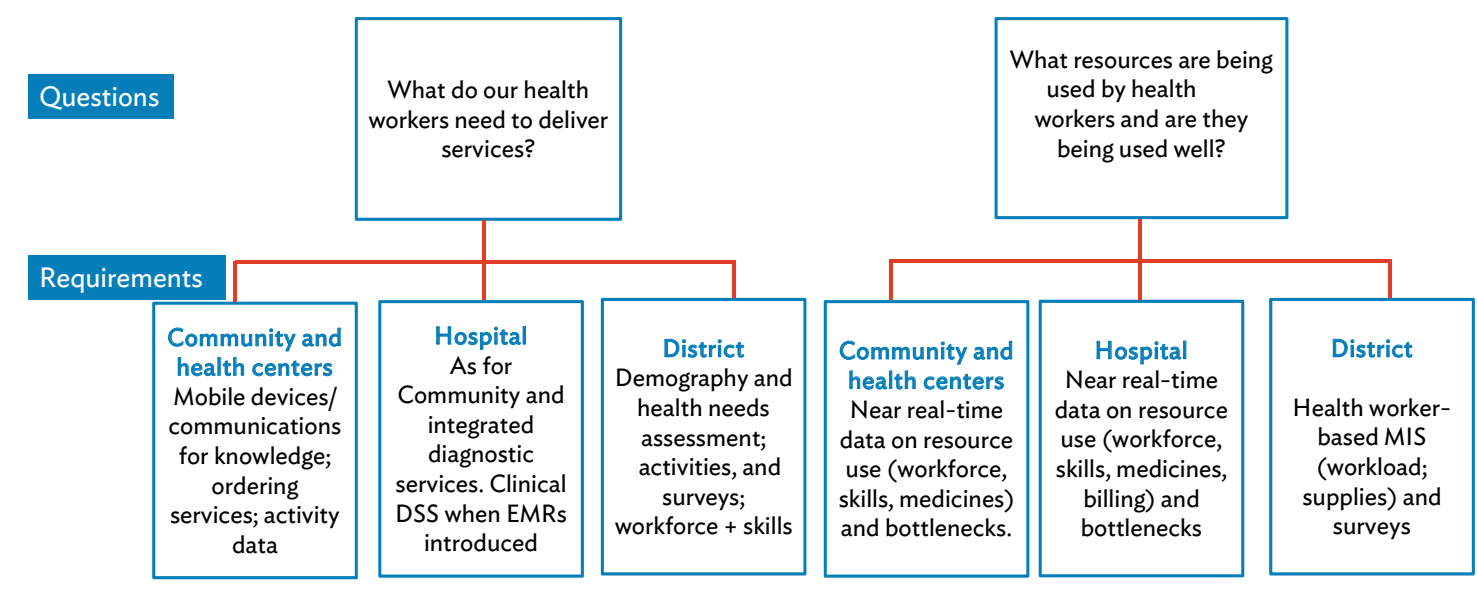

DSS = decision support system, EMR = electronic medical records, MIS = management information system .

Source: Authors.

Managers of hospitals or community services make strategic, operational, administrative, and clinical investment decisions. In doing so, managers need to be guided by the national policies and ICT, data, and governance standards to ensure that health workers can easily retrieve information from clinic or hospital information systems.

\section{Figure 14: Different Types of Decision for Different Types of Digital Solutions}

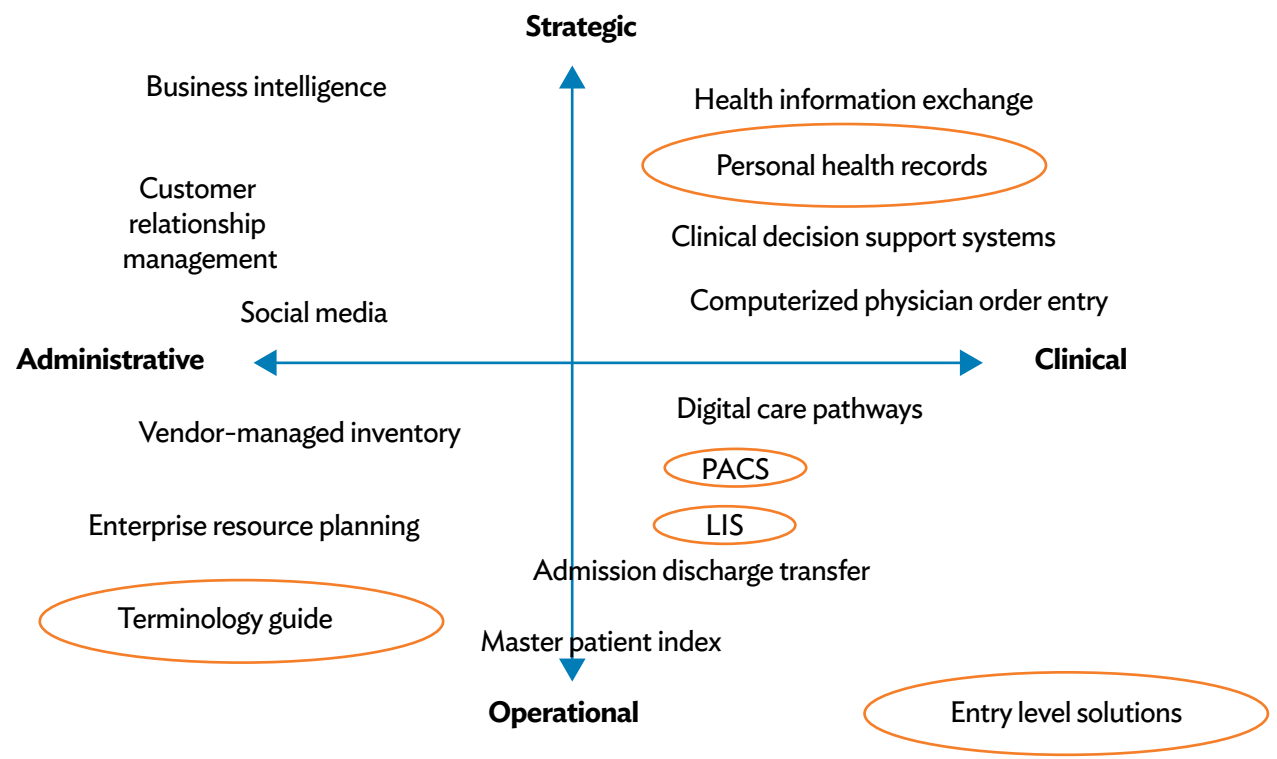

LIS = Laboratory Information System, PACS = Picture Archiving and Communication System

Source: E. Banzon. 2017. Making technology Supported Health Care the Norm. Manila: Asian Development Bank. 
Digital health investment decisions should also enable access by health workers to knowledge and diagnostic support services, and relevant logistics to ensure that drugs are available when they are needed.

As demographic and cost pressures increase, there is growing pressure on health systems around the world to deliver health care as close to home as possible (Kaneda 2006 and Monitor 2015). This requires coordination to provide continuity of care. For example, in the case of elderly patients, care may be required at home (with home alert systems) by social care services supporting home-based care, primary care for general needs, hospitals for those that require more specialist attention, and residential homes when the elderly are not able to live safely in their homes. For both caregivers and relatives, having good knowledge support to know what symptoms to watch out for and what to do is another aspect of a wellconnected digital health ecosystem. These can all be supported by high-level enterprise architecture to enable the exchange of health information, rather than having it contained only in different organizational silos. Figure 15 illustrates the requirements to support the elderly.

\section{Figure 15: To Support the Continuity of Care, Health Information Needs to be Exchanged}

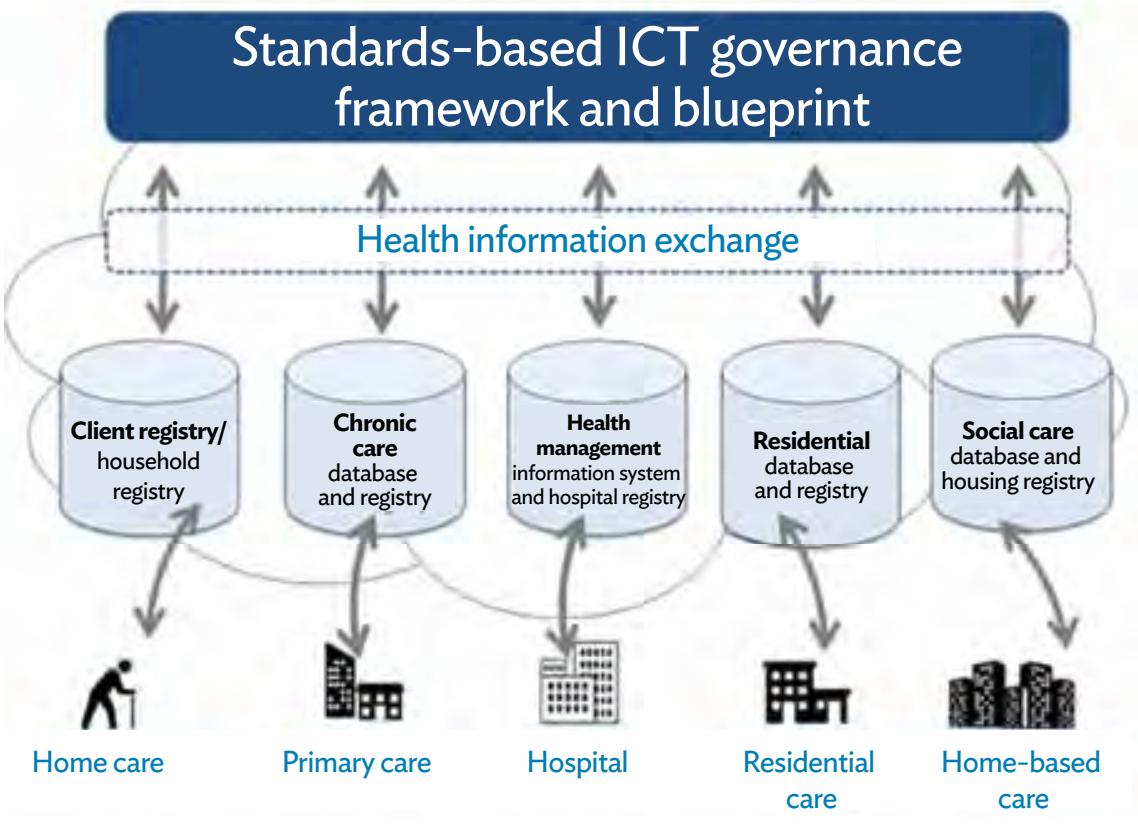

ICT = information and communication technology.

Source: E. Banzon. 2017. Making Technology Supported Health Care the Norm. Manila: Asian Development Bank.

At the district or provincial level, information about the population and its health needs, together with health service activities, enables managers to plan and monitor the provision of services and the associated requirements for resource allocation, and develop the workforce skills. This, in turn, depends on good data capture to identify utilization patterns, bottlenecks, and other problems.

Government should invest in helping managers make good decisions about the use of digital health services. An example is District Health Information Software v2, which standardizes aggregated population health data (Braa 2017). It also includes training and support in procurement (where appropriate), and developing a standardized data use culture. Investing in (near) real-time data capture and processing supports using resource use data as a by-product from operational systems. 
Additional benefits can be derived from the improved quality of data for national planning and policymaking, such as better data for clinical audit to improve performance and which can also inform hospital and clinic accreditation. Improved hospital and clinic information systems are also crucial for public-private partnership (PPP) contracts that are performance-based.

\section{E. Payers}

\section{Figure 16: Payers: Key Questions and Requirements}

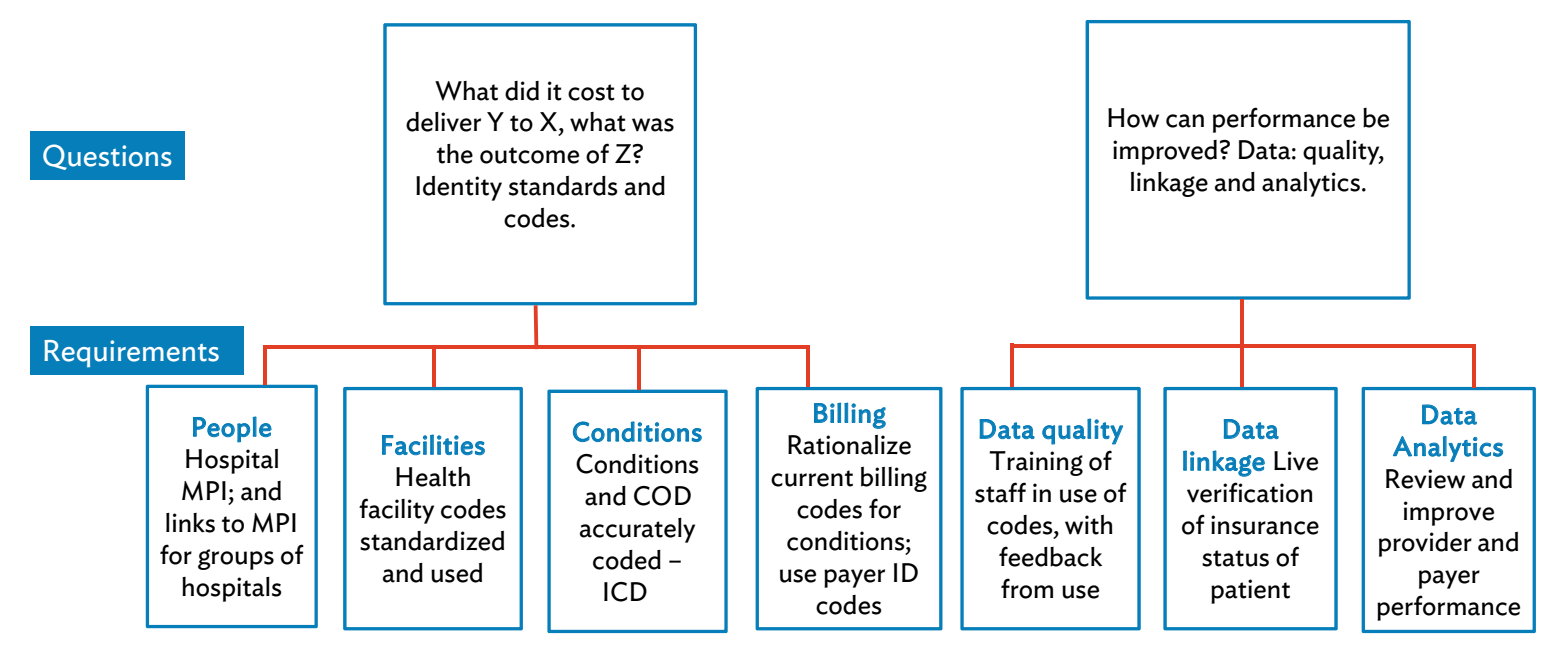

$C O D=$ cause of death, ICD = , ID = identify, MPI = master patient index.

Source: Authors.

All countries are committed to achieving UHC, and are using different strategies to do so. In more populous countries the strategy is to expand national insurance schemes. Most countries, though, are advancing UHC through a mixed model of funding. General taxation revenue and out-of-pocket payments are the primary sources of funding in Asia. In health care, "payers" generally refer to insurance carriers, other third-party payers, or health plan sponsors, and can include the patient. For payers, it is important to know what it costs to deliver services so that the right payers are billed. They have a particular interest in identity standards and codes. For health organizations, better information flows mean faster and more accurate reimbursement.

Governments should invest in master patient indexes within hospitals, and across groups of them. This requires policies and standards for unique patient identification, conditions, diagnostics, treatments and facilities, billing and payer ID, and the training to implement them. Agreements on governing prices for remote health care delivery, such as telehealth and mHealth, are key. Information exchange between health ministries and insurance agencies is needed to monitor if investments in health insurance actually improve health outcomes. Both health care organizations and payers have an interest in improving their own performance, as well as that of the other party. Digital health systems enable this.

Government investment and payer investment support continuing improvements in data quality, data linkage, and data analytics to support performance improvement. 


\section{Box 3: Philippine Health Insurance}

When Philhealth imposed a mandatory electronic claim management, hospitals started to digitalize and invest in their information systems and interoperability.

Source: J. de Dios. 2016. PH healthcare industry set for growth. 9 May. http://business.inquirer. net/210155/ph-healthcareindustry-set-for-growth (accessed 8 January 2018).

Additional benefits can come from data linkages with work injury schemes showing where preventable injury risks are unacceptably high. Linking payer management information systems (MIS) to national CRVS or client ID registries can help reduce fraud and speed payment. Also, it is easier to introduce performance and value-based payments for providers; for example, in PPPs. Performance analytics help improve more strategic purchasing of medicines and supplies. Pension schemes and social protection programs also benefit from a more detailed insight into patterns of health need and behavior. With better research into the latter, payers can offer incentives (as their costs are reduced) to encourage healthy behavior (and should be encouraged to do so).

\section{F. Investors and Donors}

Investors - whether they are mobile network operators (MNOs), medical technology companies, pharmaceutical organizations, or private health care providers-need up-to-date information about the part of the health system that they are interested in. To minimize risk and maximize return, many will invest in market intelligence-gathering data about the need, demand for, and supply of services relevant to them. Similarly, donors want to know what they should provide, where it is most needed, and where the biggest impact can be made. For example, there may be a particular focus on supporting investment in CRVS solutions (Duffus 2015).

\section{Figure 17: Investors and Donors: Key Questions and Requirements}

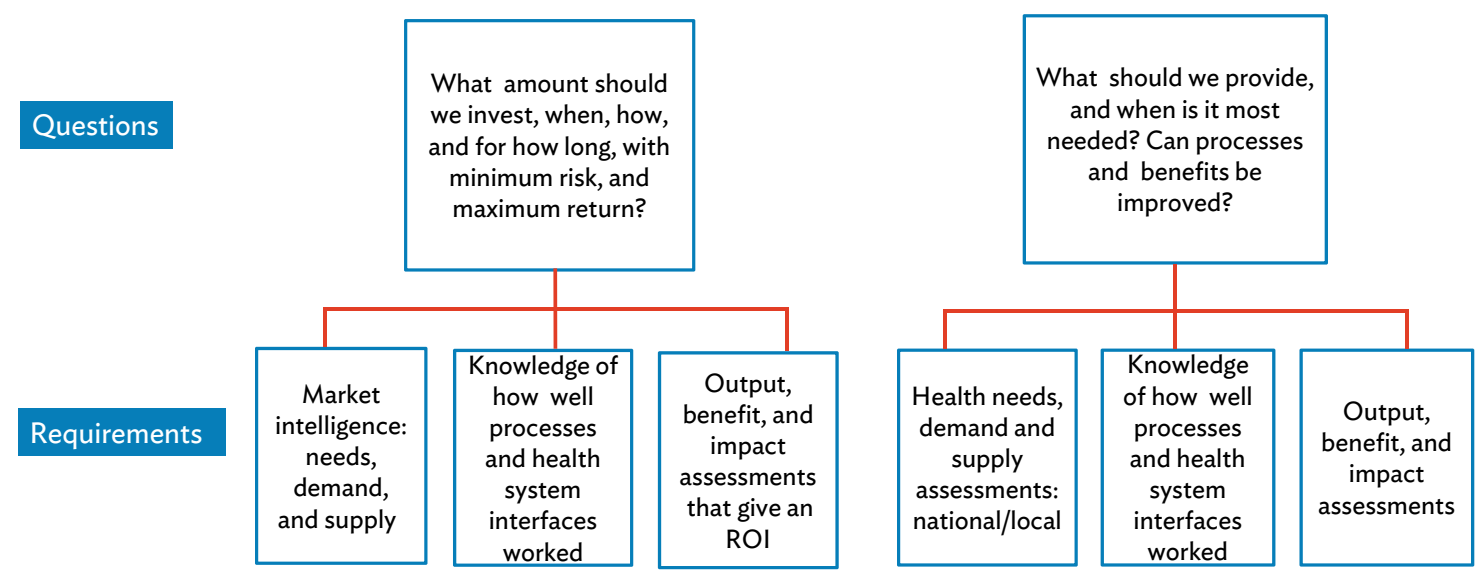

$\mathrm{ROI}=$ return on investment.

Source: Authors. 
Again, they require a needs assessment to understand where processes and health system interfaces can be improved. Both investors and donors want to know the likely (and actual) output and benefits of what they are funding, and how long it will take to deliver them; this affects estimates of VFM and affordability.

\section{Box 4: Investor Perspectives on Digital Health Return on Investment}

- How can digital health ensure people's engagement with their health?

- How can one objectively quantify behavior change?

- How does a solution fit into clinical work flow?

- Can the solution be taken to scale?

- Does the innovation produce value for the organization?

Source: A. Adler. 2016. MedCity News. 8 August. https://medcitynews.com/2016/08/defining-digital-health-roi-5-elementsmight-actually-make-sense/ (accessed 26 November 2017).

Government should invest in governance mechanisms to improve coordination with investors and donors, and align their interests with national and local health priorities. Mutual sharing of information about potentially available funding support or incentives can save investments. The mechanism should establish effective interoperability and enterprise architecture, both based on digital standards (technical and management) that investors and donors agree to comply with or progressively align to. The socioeconomic return of investing in interoperability testing facilities, and supporting innovation hubs to nurture local digital health entrepreneurs, should be assessed. PPPs can offer new opportunities and challenges for digital health investment.

Additional benefits from wisely planned digital health information systems should enable governments to encourage and guide potential investors and donors. For example, government may have stored data that enable innovative investment partnerships with pharmaceutical companies wanting to run "realworld" drug trials (Bonnelye 2015). Similarly, once interoperability standards are agreed, donors can be guided to support health systems strengthening with more focus on cross-sector working.

\section{G. Planners and Policymakers}

Planners and policymakers need to know what is actually being delivered by the health systems to whom, where, for what, by whom, using what resources, and with what outcomes. Good MIS on (clinical) activity and workforce, surveys, and population health and disease surveillance requires digital health solutions.

Government investment is needed to directly or indirectly (e.g., via donors) ensure that MISs derive data from the clinical and operational requirements of health workers, and with near real-time data capture. Knowing about activity volumes without being able to relate this to clinical data, workforce, financial, and logistics management systems, limits insights for planners and policymakers. Governments and IDPs may need to help with needs assessments, demand and supply analysis, or with surveys. Surveys can be expensive, but they can be minimized if a reliable health information system is in place. Also, additional information for surveillance, research, and policy-making about disease prevalence, outbreaks, epidemics and epidemiology, and understanding health hazards (from floods, storms, and drought) may require investment in capturing data via both mobile and remote sensing.

The key questions for policymakers are: How can digital health systems help improve health system performance? What investments are required? Good information governance and leadership can manage the risks of digital systems. And, if these are done correctly, the potential of new data management 


\section{Figure 18: Planners and Policymakers: Key Questions and Requirements}

\section{Questions}

Requirements

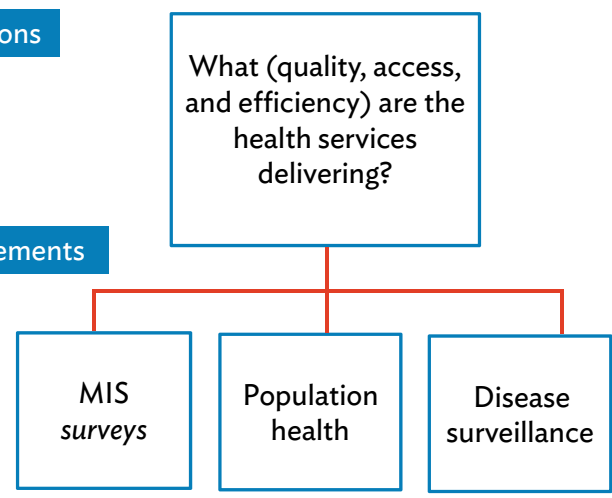

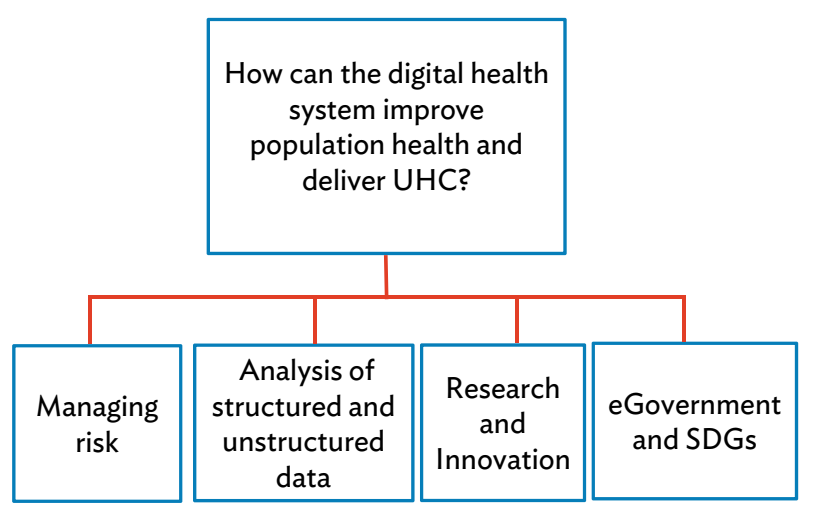

MIS = management information system, SDG = Sustainable Development Goal, UHC = universal health coverage.

Source: Authors.

technologies that can handle both structured and unstructured data offer rich insights into what has been going on, and what can be predicted.

Government investment in MIS (such as District Health Information Software v2), databases, and data warehouses (which can be cloud-based) enables researchers to use powerful data analytics to interrogate anonymized data, and then leverage further private sector or IDP funding and investment in innovations such as new mHealth apps, drugs, and service delivery. Also, planners and policymakers need more cross-sector data to understand how they are making progress in delivering UHC.

\section{Box 5: Return on Investment in Prevention}

There is a return of 14:1 for money spent on public health interventions. For every 1 unit invested, 14 will be returned to the wider health and social care economy.

Source: R. Masters, E. Anwar, B. Collins et al. 2017. Return on investment of public health interventions: a systematic review. Journal of Epidemiology \& Community Health 0: pp. 1-8.

Additional benefits will be derived as better data on costs and benefits of vertical disease programs are assessed (ADB 2017). Also, digital health investments provide the foundations for supporting countries (communities and enterprises) in meeting the wider SDGs.

The principles for digital development and digital investment apply also to digital health.

The nine principles (Digital Principles Forum 2017) are an attempt to unify previous principles and create a community of practice for those who work in digital development. They were first created in consultation with organizations such as Bill \& Melinda Gates Foundation, the Swedish International Development Cooperation Agency, the United Nations Children's Fund, the United Nations Development Programme, the World Bank, the United States Agency for International Development, and WHO. The Digital Impact Alliance Community acts as steward for the forum. In the interest of promoting more effective digital solutions and rational use of government and donor funding, a digital health investment tool is being developed to translate 


\section{Box 6: Principles for Digital Development}

- Design with the user.

- Understand the existing ecosystem.

- Design for scale.

- Build for sustainability.

- Be data-driven.

- Use open standards, open data, open source, and open innovation.

- Reuse and improve.

- Address privacy and security.

- Be Collaborative.

Source: Principles for Digital Development. https://digitalprinciples.org/.

the principles into action. The goal is to help ministries of health, funders, and implementing partners rate a project's adherence to the principles. This tool seeks to break down the principles into a set of scoring criteria and resources that can be applied to guide in making investment decisions.

\section{H. Governance}

Governance mechanisms are crucial to manage stakeholder interest and make good digital health investment decisions. There are different forms of governance mechanisms available. The Broadband Commission for Sustainable Development (Broadband Commission 2017) suggests the following options:

\section{Figure 19: Different Options for Managing the Development and Delivery Process}
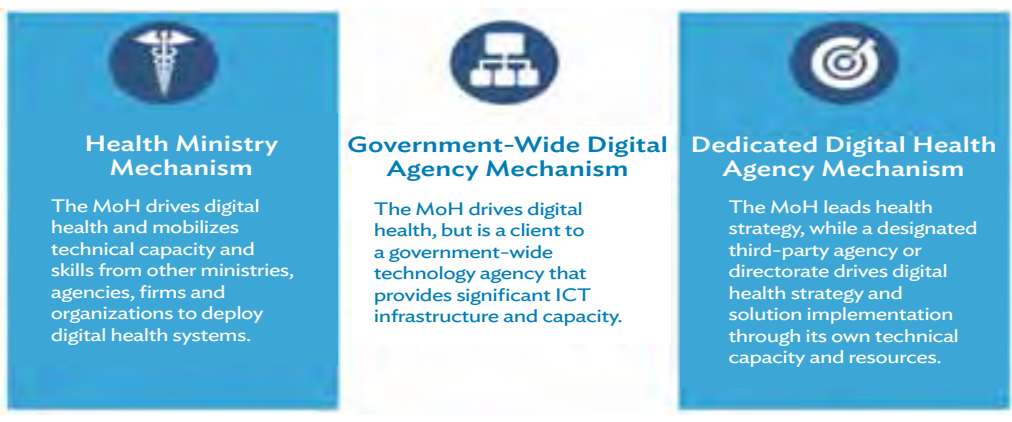

The digital investments that need to be made can be those best done nationally, or those best done locally by the stakeholders involved. Investment decision-making processes need to be understood in each case

$\mathrm{ICT}=$ information and communication technology, $\mathrm{MOH}=$ Ministry of Health.

Source: Broadband Commission for Sustainable Development (2017 cp2).

The Philippines is an example of the health ministry mechanism; Malaysia's Administrative Modernisation and Management Planning Unit of a government-wide digital agency mechanism; Canada's Infoway of a not-for-profit, third-party dedicated digital health agency mechanism.

Another approach is to work with development partners to evolve a strategic approach to digital health investments. For example, in Tanzania, PATH, with support from the Bill \& Melinda Gates Foundation, led work that resulted in investment recommendations concerning "the journey to better data for better health in Tanzania" (Appendix 5). 


\section{DIGITAL HEALTH INVESTMENT PROCESS}

\section{A. Introduction}

- Digital health systems have different investment profiles. They vary with the complexity, cost, people affected, and over time. Digital health strategies should guide the investment cases to be developed at the national level.

- The digital health investment cycle frames the selection of investments for appraisal, associated handling of key questions for each of the stakeholders involved, and managing shared assets.

- A brief introduction of the digital health impact framework and its 10 key steps shows how it can guide assessments of socioeconomic returns, affordability, and timescales. More detail is provided in the accompanying Digital Health Impact Framework manual.

- Five hypothetical use cases (with details and associated spreadsheets) illustrate how the digital health impact framework can be used, both for individual projects and strategic programs to understand the impact of risk exposure and options for mitigation.

- Balancing requirements, solutions, and benefits for different stakeholders requires both management and technical foundations to be in place. But digital health can deliver a wide range of benefits of efficiency, quality, and access.

To deliver better health and health care by investing in digital health, we must understand what the intended, estimated, and probable inputs, processes, outputs, and benefits are. One aspect of improving better quality of care (by developing the knowledge that supports decision-making at POC) is illustrated in Table 2, along with examples of two strategic investments to improve health care delivery.

\section{Table 2: Benefit Pathways: Examples from Delivering Better Quality of Care,} and Key Strategic Investments

\begin{tabular}{|c|c|c|c|c|}
\hline Intervention & Inputs & Process & Output & Benefits \\
\hline \multicolumn{5}{|c|}{ Better quality of care } \\
\hline $\begin{array}{l}\text { Use of } \\
\text { knowledge } \\
\text { support at } \\
\text { the POC }\end{array}$ & $\begin{array}{l}\text { Evidence-based clinical } \\
\text { guidelines; }\end{array}$ & $\begin{array}{l}\text { Testing; localization; } \\
\text { authorization } \\
\text { dissemination; training } \\
\text { installation }\end{array}$ & $\begin{array}{l}\text { Mobile devices with } \\
\text { knowledge support } \\
\text { apps used at POC, timely } \\
\text { information }\end{array}$ & $\begin{array}{l}\text { Better care decisions, } \\
\text { e.g. diagnosis referral, } \\
\text { medications }\end{array}$ \\
\hline \multicolumn{5}{|c|}{ Strategic investments } \\
\hline $\begin{array}{l}\text { National Health } \\
\text { Enterprise } \\
\text { Architecture }\end{array}$ & $\begin{array}{l}\text { National Strategy for the } \\
\text { Health Sector; Digital } \\
\text { Health Strategy/eHealth } \\
\text { Strategy }\end{array}$ & $\begin{array}{l}\text { Measurable goals and } \\
\text { objectives-efficiency; cost } \\
\text { Reductions, etc. } \\
\text { Review and refine }\end{array}$ & $\begin{array}{l}\text { Agreed IT assets; } \\
\text { standards, tools, and } \\
\text { metrics are in use; IT } \\
\text { infrastructure aligns with } \\
\text { health system priorities } \\
\text { and requirements }\end{array}$ & $\begin{array}{l}\text { Health information } \\
\text { system interoperable, } \\
\text { and IT goals delivered } \\
\text { with more integrated and } \\
\text { coordinated care and less } \\
\text { cost }\end{array}$ \\
\hline $\begin{array}{l}\text { Backbone } \\
\text { infrastructure }\end{array}$ & $\begin{array}{l}\text { eMail, voice, file transfer, } \\
\text { cloud storage/data center } \\
\text { requirements for all users } \\
\text { Legacy network }\end{array}$ & $\begin{array}{l}\text { Quality of service } \\
\text { requirements; business } \\
\text { case and procurement } \\
\text { process }\end{array}$ & $\begin{array}{l}\text { Preferred supplier solution } \\
\text { implemented, user } \\
\text { Training, QOS and User } \\
\text { acceptance completed }\end{array}$ & $\begin{array}{l}\text { Network enables registers, } \\
\text { apps, and users to } \\
\text { interoperate and deliver } \\
\text { improved health care }\end{array}$ \\
\hline
\end{tabular}

$\mathrm{IT}=$ information technology, $\mathrm{POC}=$ point of care, $\mathrm{QOS}=$ quality of service.

Source: Authors. 
Figure 20 shows the approach used by the Global Financing Facility (World Bank 2016) to develop an investment case framework that will support the required investment.

\section{Figure 20: Investment Case Framework}

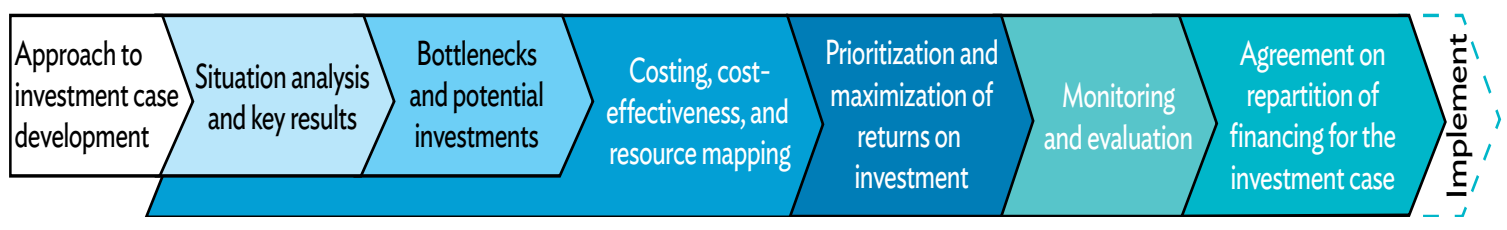

Source: Global Financing Facility (World Bank 2016).

Although investment in digital health may not decrease the overall expenditure (indeed, overall expenditure may increase as usage increases because of the cost of ICT with more users, extended networks, wider scope, functionality, interoperability, and population growth, or greater efficacy generating greater usage), it can reduce unit costs for specific services and increase benefits in terms of health outcomes. Digital health's socioeconomic return also depends on the timing of costs and benefits. Benefits accrue often only over a long period of time.

Appendix 4 addresses in more detail potential areas for maximizing patient-related benefits, and indicates areas for investments in technical solutions, basic infrastructure, and registries.

\section{B. Digital Health Investment Case Cycle}

The term "investment case" is used to identify, analyze, estimate, and evaluate the reasons why there is a probable net benefit in investing in a particular project, program, or system. The investment is not just in technology, but also in all the other components, especially human capacity and capabilities, governance, standards, architecture, usability, and organization needed to enable an investment in digital health deliver benefits within an acceptable time period (ADB 2018). Some investment cases may be for small-scale and perhaps stand-alone solutions, which can be delivered in a short time frame. But, for many solutions, around 5 years are needed to reach net benefits (Stroetmann et al. 2006). For larger-scale digital health solutions, it may take an average of 9 years (Stroetmann et al. 2010).

The complexity/cost of what is required (e.g., development, technical, and organizational aspects) and the number of people that it will affect/benefit are key parameters to determine the required investment profile (Dobrev 2008). Some solutions are already developed and ready to be supplied (e.g., supplies and diagnostic systems), while others (e.g., EHRs) may need joint development with suppliers.

Figure 21 provides an overview of digital health solutions and the relation of complexity/cost and people affected. In quadrant 1, the solutions are relatively low-cost (governance, standards, and ICT) and affect many people. The solutions in quadrant 3 are more expensive and affect fewer people. Across different countries, perceptions of the relative value of improved outcomes for patients in hospital vary, compared with the outcomes of improved delivery of public health information and health behaviors. There is a general shift in many Organisation for Economic Co-operation and Development countries from a system focused on managing provider performance, to solutions based on strengthening health and quality of life (Snowden 2012). Depending on the assessment of the health and socioeconomic context of a country, its values and digital maturity (Johnston 2017), the pathway a country chooses, and the investment priorities it has, will likewise vary. 
New approaches are emerging to make more rapid progress (Chapter $\mathrm{V}$ ), but experience to date in investment appraisal and evaluation suggests that shortcuts are risky, especially in large, complex programs.

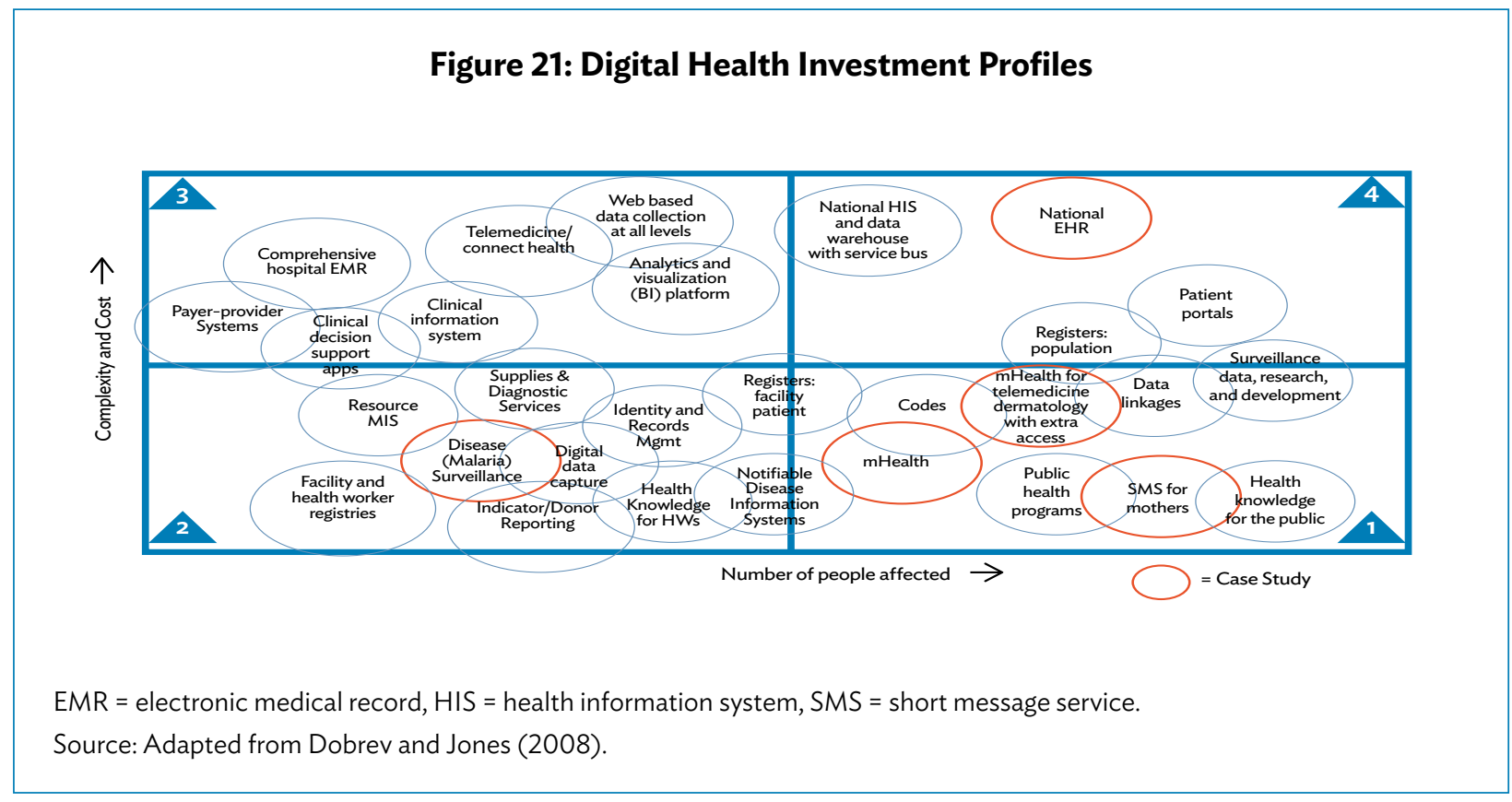

For investment in digital health to achieve fullimpact, as the model below suggests, (relevant) stakeholders need to be engaged. Some of their key questions and requirements have already been considered. To meet them, different types of resources (including financing of different sorts) and data are required.

There are a variety of systems current at any given time. Some may be paper-based, while others use different types of digital solutions. Depending on their performance, an investment case for a better digital solution then needs to be made. This appraisal process, guided by the digital health impact framework (DHIF), is considered in more detail below (see also Appendix 2, which provides a summary of the DHIF, the accompanying DHIF User Guide and Manual). Having implemented a solution, its performance needs to be monitored (and improved) with analytical tools.

From the digital health investment case perspective, the key is to know if a sound investment case can be made to support a particular solution (which may be relatively simple such as SMS, or complex and costly like an EHR).

Both current and new systems need to be supported by good foundations (both managerial and technical) to deliver actual information output to one or more groups of users. The performance of these foundations must be reviewed and improved upon. Particularly where digital technology solutions are required, the same DHIF appraisal process can be used to guide an investment. We also need to invest in digital health skills and knowledge, and the competencies and capabilities of the workforce in general, including specialist ICT, informatics, health analytics, and cybersecurity skills. 


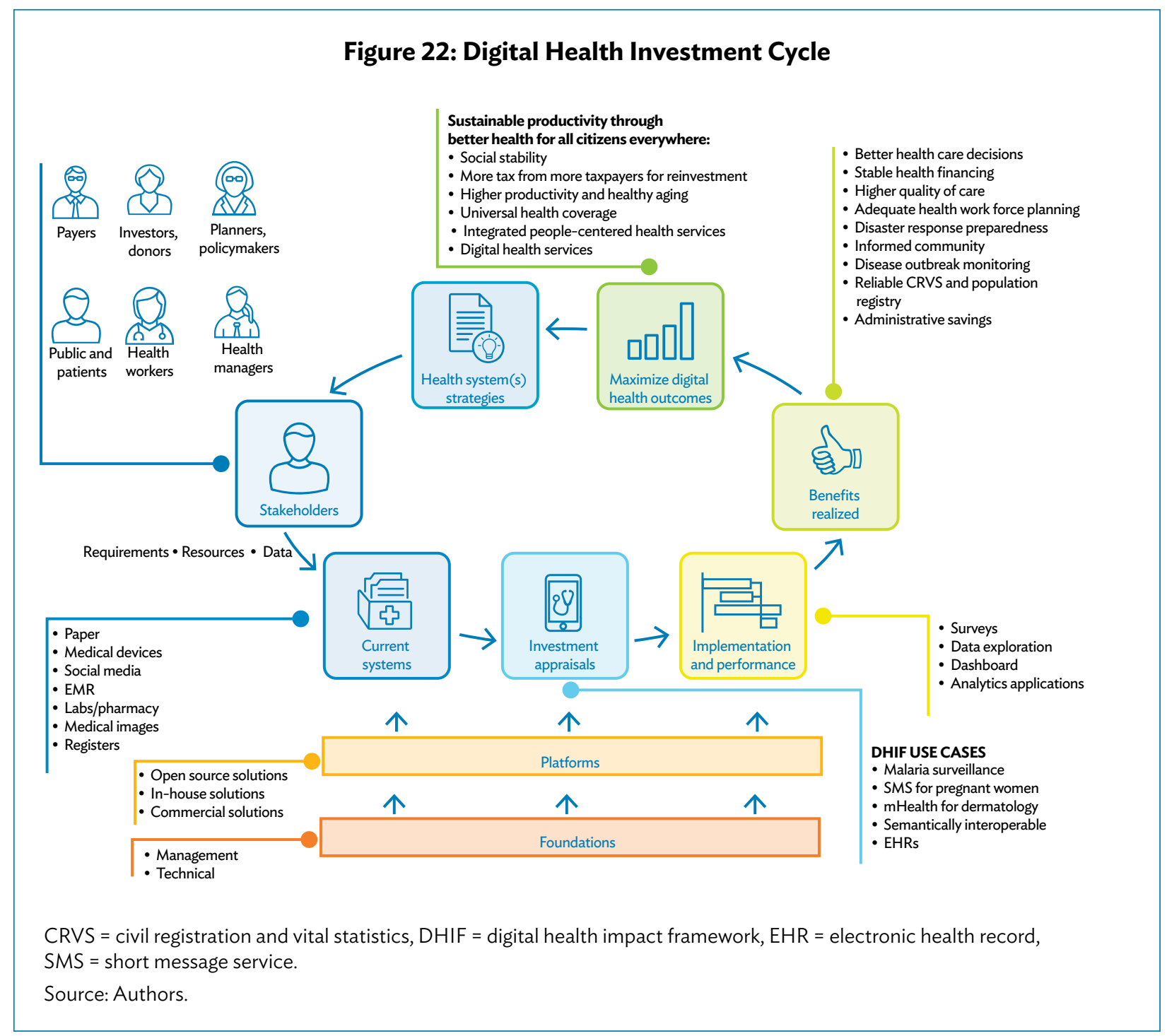

Foundational technical infrastructure investments are typically long-term, relate to the geography and population of a specific area, and are highly interconnected and interdependent. Some may be small-scale, but when they are part of a large program of investments, the benefits may be greater that those from individual investments. Also, infrastructure with new applications may enable new ways of delivering new services, such as mobile broadband enabling new telecare services, and new preferences and behaviors may be shaped as a result.

Over time, all these considerations determine whether there is VFM and an appropriate return on investment (ROI).

The value of investment in a well-managed digital health infrastructure should increase as its use becomes universal and it enables stakeholders to receive digital services (though, over time, it will decrease as obsolescence builds). This "network" effect is difficult for the private sector to achieve, but it needs to be part of a government policy that recognizes the value of investment in a public good. It follows that digital health must then ensure that the investment case for digitally supported services is strong, and that there are sufficient people with the necessary skills and knowledge to support an evolving suite of services and manage the associated programs. Then, the intention should be to leverage digital health's usability and utilization to realize the maximum benefits as rapidly as possible. 
Figure 23: Foundations for Delivering Benefits

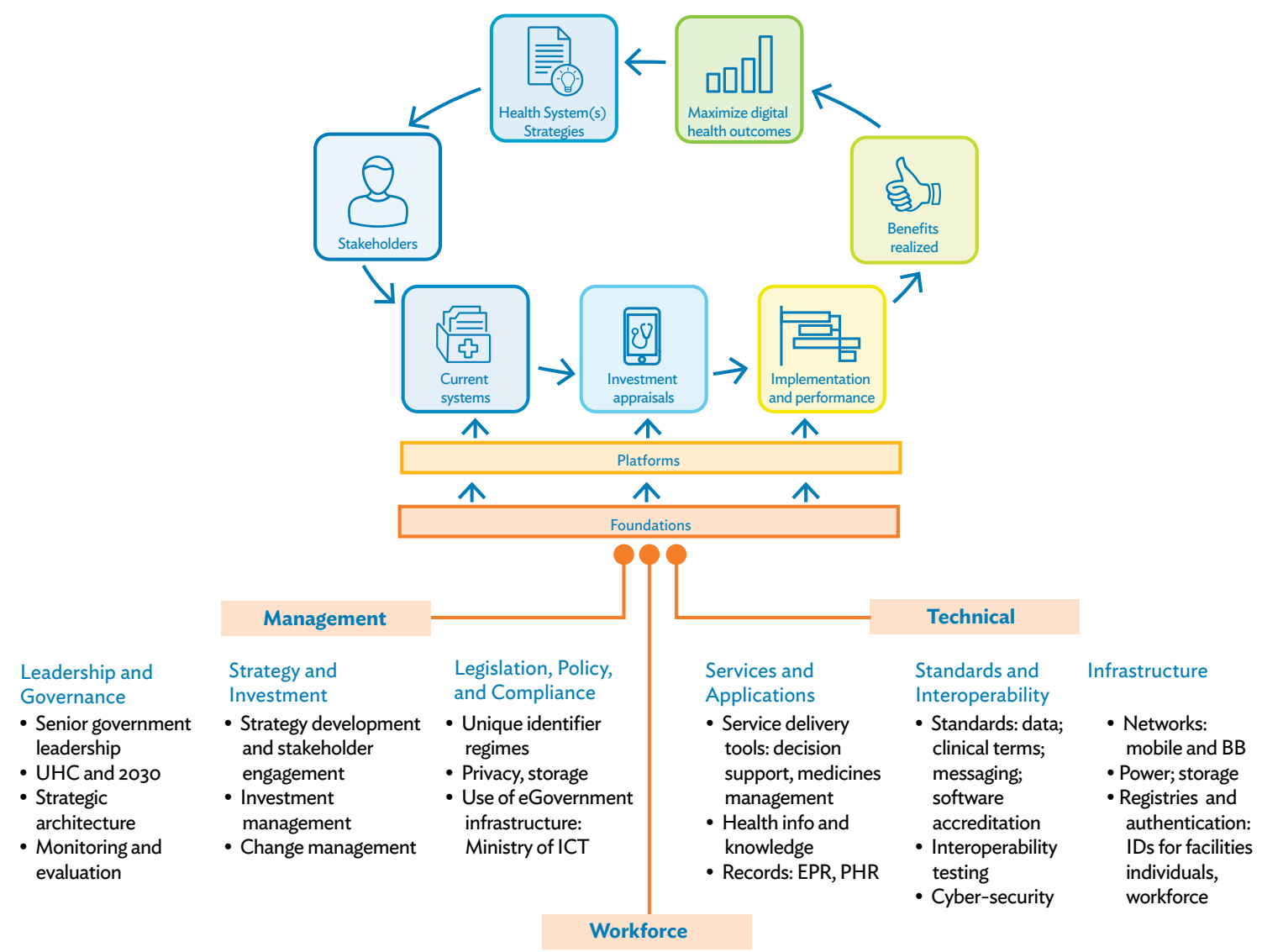

Digital health skills for the health workforce; and specialist skills for the health ICT workforce

$\mathrm{BB}=$ broadband, $\mathrm{EPR}=$ electronic patient $/($ medical) record, $\mathrm{ICT}=$ information and communication technology, ID = identity, $\mathrm{PHR}=$ personal heath record, $\mathrm{UHC}=$ universal health coverage.

Source: Authors.

PPPs should be explored, especially for larger-scale digital health projects (Roehrich 2014). For example, governments may provide the key assets of the public health infrastructure, funding (seen as key by the private sector), and wider population reach; health tech companies devices, health expertise, and global reach; and MNOs connectivity, ICT capabilities, and customer relationships. For digital health PPPs to be successful, good governance is key, which ensures data ownership, privacy, security, and information standards.

Risk is an important component of PPPs. Allocating risk means deciding which party to the PPP contract will bear the cost (or reap the benefit) of a change in project outcomes arising from each risk factor. Allocating project risk efficiently delivers better VFM through PPPs (World Bank 2017). When allocating risk between partners, the public sector partner must understand the relationship between risk and reward. Private sector partners are not likely to take on or share extra risks without extra reward, and so cost to public sector partners. Affordability constraints can mean that risk transfer and substantial risk-sharing are rarely achieved in PPPs. Good information systems are crucial to monitor and evaluate performance. 
Chapter III has shown some key digital services that are required. Figure 24 illustrates that these services are (often) needed by more than one group of stakeholders. These digital services need to be supported by a set of shared assets, although not all of them have to be in place to deliver the key digital services. Some, such as health knowledge, have no confidentiality requirements, while others - such as health records - do (along with many other supporting standards and services). Also, the foundations must be kept up-to-date via the same process of (DHIF) investment appraisal.

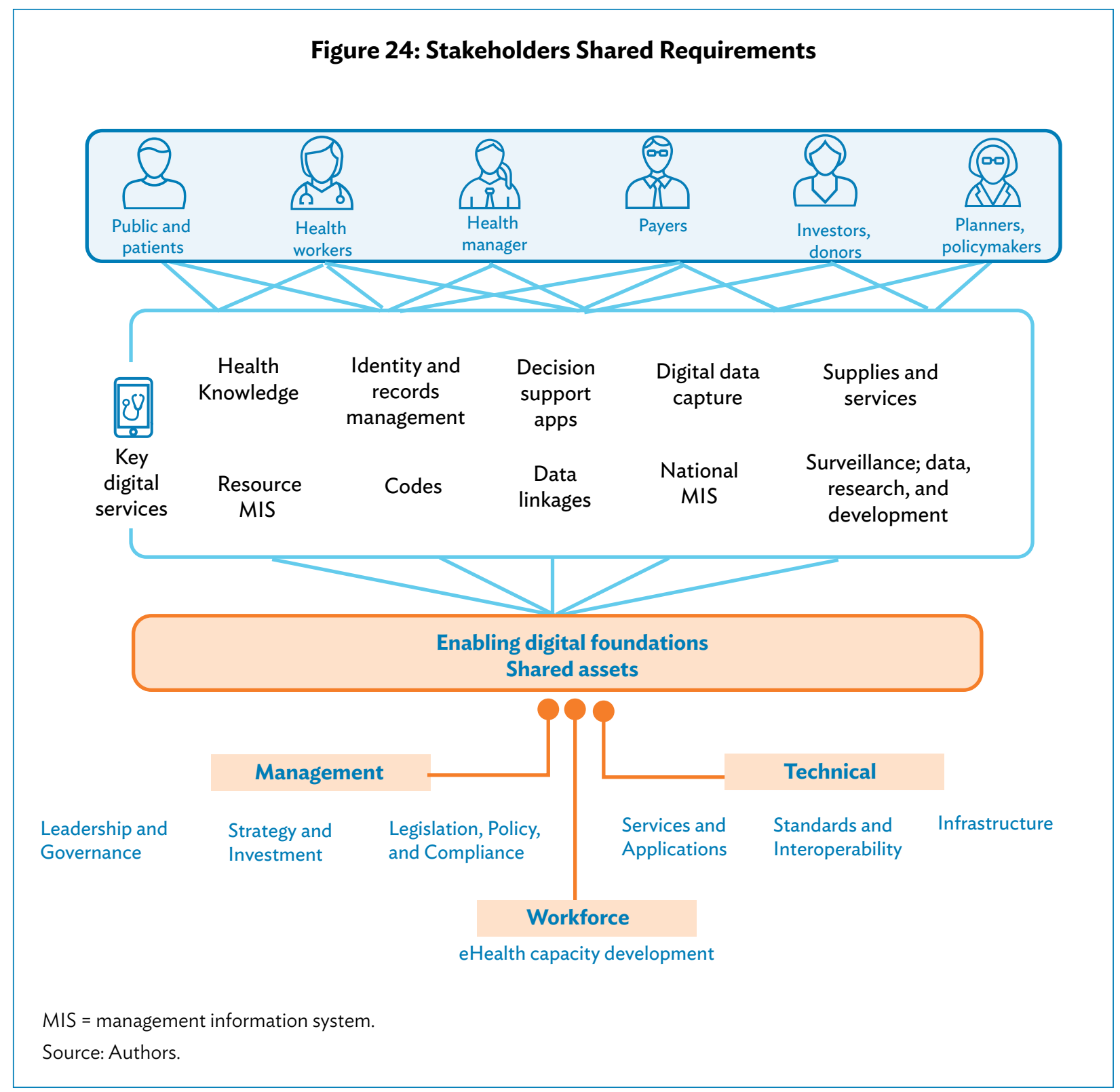

With the right foundations and solutions, governance arrangements, and programs for change and adoption all in place, extra investment may then be able to realize additional benefits. For example, expanded interoperability can enable national implementations of CRVS and national ID schemes, knowledge support platforms for communities to include all SDGs, increased resilience in emergencies, better response to epidemics, better identification of health hazards, more effective national insurance schemes, and a healthier population. 


\section{Building a Digital Health Investment Case}

Digital health investment has many variables that have to integrate to achieve the required benefits. When investment risks are not mitigated, and these variables are not in place properly nor integrated, digital health investment fails (ranging from insufficient benefits to abandoning projects completely).

Success begins with rigorous investment appraisal, starting at an early stage in the investment cycle. This, in turn, requires a generic methodology that enables bespoke appraisals like the DHIF approach (Dobrev et al. 2008 and 2010, and Appendix 2). It has five main components for each program or project:

(i) Strategy. Fit to the national and digital health strategy objectives; identify benefits in terms of quality, access, and efficiency (Appendix 2).

(ii) Socioeconomics. Determine the estimated socioeconomic impact for each option that combines into the impact for the whole strategy, including the proposed digital health solutions, stakeholder types, costs, benefits, net benefits, and VFM, for all investment options and their timelines, and for all stakeholder types.

(iii) Financial impact. This includes additional extra capital and operational cash flows for all stakeholder types and income and expenditure, using the accruals methodology, compared with budgets, financial plans, and other sources of finance, to estimate affordability.

(iv) Human digital health capacity. Requirements for leadership and management to ensure effective decision-making, stakeholder engagement, planning, development, risk mitigation, procurement, implementation and project management, operation and utilization, and changing management and benefits realization of the strategic goals.

(v) Commercial implications. Changes to health care pricing, relationships with partners and thirdparty payers.

Appraising socioeconomic impacts incorporates all the features of strategy, leadership and management, and commercial requirements in seeking VFM, measured as a socioeconomic return.

Whether the concern is with a national digital health infrastructure, the purchase of a hospital information system, or a logistics MIS, the objective is to reach the endpoint of a digital health investment decision with an optimal relationship between the socioeconomic net benefits (socioeconomic return) and financial affordability. The socioeconomic return is a set of ratios of socioeconomic costs and benefits over time; in other words, net benefits. It is for all stakeholders and each type of stakeholder; each is compared with adjustments for sensitivity, optimism bias, and risk exposure.

DHIF is about the probabilities of socioeconomic return, affordability, and timescales. Other perspectives, such as potential and predictions, overstate digital health's socioeconomic return. Digital health's potential can be huge, but seldom do all users take advantage of all its functionalities. Neither do all potential users participate from the outset, deferring potential utilization, and benefits. Those that do can sometimes find benefit realization is more challenging and time-consuming than envisaged. Since these lead to unrealized potential, seeking a probable net benefit is more realistic.

The uncertainties about digital health being a complex adaptive system reinforce the inevitable changing nature of digital health projects as they proceed along their time lines. It also confirms that small-scale pilots should be designed for scale based on DHIF. Assumptions and estimates (A\&Es) need to change to match their dynamics, so they cannot be seen as predicted outcomes. DHIF's role is to help find a probable optimal relationship between socioeconomic and financial estimated costs, benefits, and time. Yearning for something bigger, better, and faster seldom delivers and increases risks. A good example is assuming that all health workers will use all the functions in a digital health project on the day after implementation, and that all benefits will be realized on that day. This is the potential; the probability is a lot less. 
ICT without health care transformation leads to skewed net benefits. Just because they are both in place does not guarantee maximum benefits. A study (Kern 2014) in a patient-centered medical home model of primary care found that EHRs plus organizational change give the greatest quality improvement. EHRs alone are not enough, and neither is combining them. Barriers to success remain, especially for complex care management (Hong 2014), which include:

(i) fee-for-service payment system minimizes incentive to change;

(ii) lack of capital for start-up costs, including digital health;

(iii) unrealistic expectations for an $\mathrm{ROI}$ in less than 3 years;

(iv) lack of experience and knowledge of operational details inhibit design and implementation;

(v) high-quality training programs are not widely available;

(vi) better algorithms are needed to identify patients whose care offers the greatest opportunity for reducing expenditures;

(vii) HIEs must provide real-time data;

(viii) better integration of available products into comprehensive EHRs could accelerate adoption; and

(ix) performance standards for these platforms might help providers navigate the increasingly complex digital health and ICT vendor terrain.

Dealing with these factors, and others specific to different types of digital health, and the settings in which they are pursued, should be included in DHIF models.

Digital health enablers are important too. They include:

(i) supplemental payments to help with start-up costs;

(ii) sufficient duration for implementation of 3-5 years;

(iii) close collaboration between all providers caring for assigned patients;

(iv) integration of providers of behavioral health care;

(v) sharing key resources such as patient registries, health ICT platforms, networks, and analysts; and

(vi) creating organizational homes for shared resources.

These illustrate the costs, opportunities, changes, and risks of modern digital health. They can be reflected in digital health socioeconomic and finance models, such as DHIF, so decision-makers can test and establish them in advance of an investment.

A simplified version of the DHIF assessment process for a proposed solution has 10 steps (Figure 25). Within these, there are a more detailed series of steps (Appendix 2) and the accompanying DHIF User Guide and Manual.

For each specific project or program, we need to come up with a bespoke investment case model that states clearly what the A\&Es are which have been applied, as these will need to be rigorously tested. Source of A\&Es data include:

(i) local information systems, such as catchment populations and communities, and accounting and costing data;

(ii) local research on health needs and probable responses; and

(iii) transferable research.

Also, these need to provide the initial data required for financial and affordability appraisals. 
Figure 25: 10 Key Steps in Developing a Digital Health Impact Framework

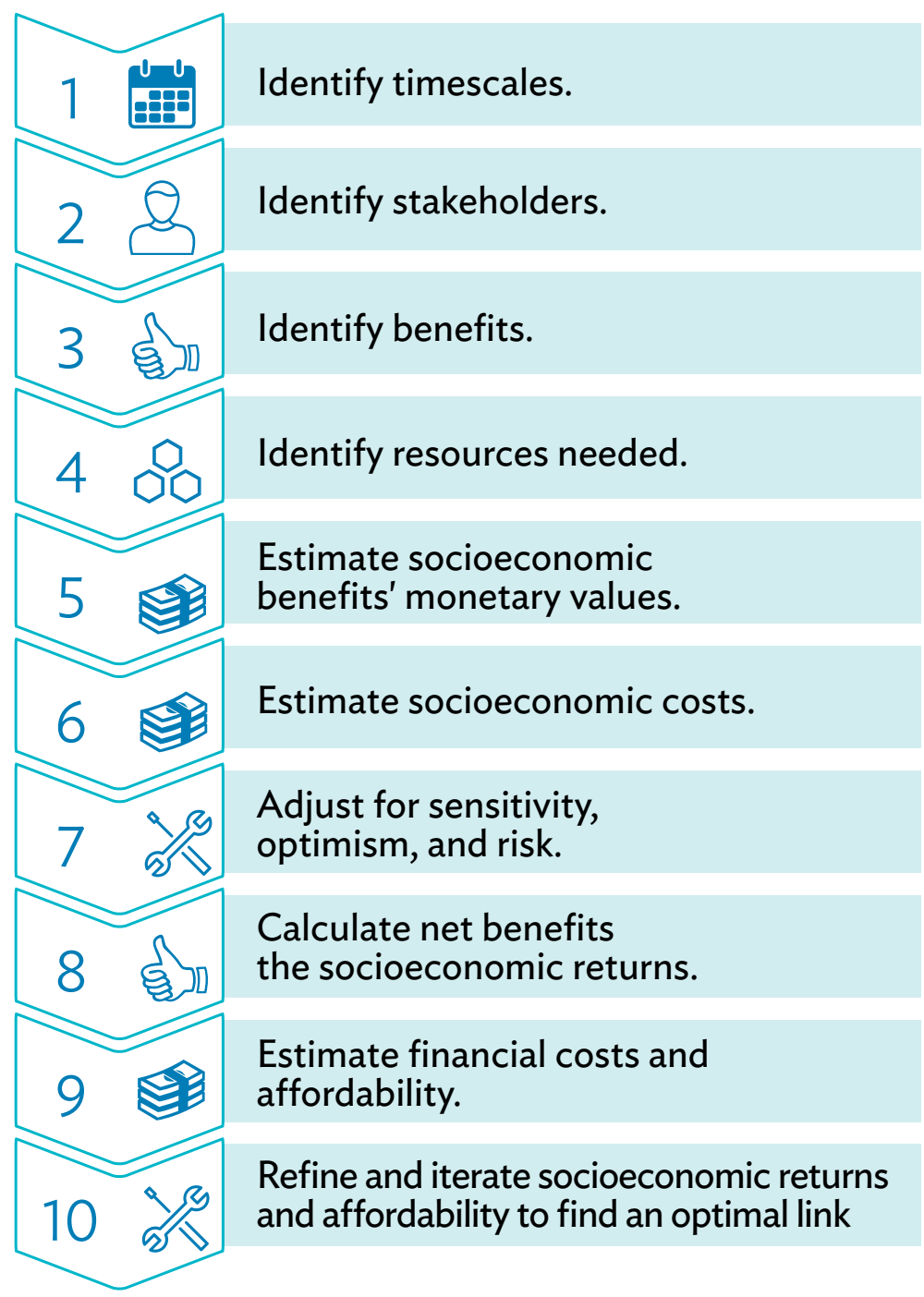

Source: Authors.

There are four possible results:

(i) A preferred option has an affordable positive socioeconomic return that passes the sensitivity, optimism bias, and risk exposure adjustments described below.

(ii) It does not pass the adjustment tests and is not affordable, but after iteration, an optimal relationship is found.

(iii) It does not emerge from iteration, so it has to be replaced with another option.

(iv) None of the options produce a positive socioeconomic return, so the whole project does not go ahead. 
All options should be based on estimated probable data. The results are less than digital health's potential, which-as experience from project evaluations suggests-is seldom, if ever realized.

DHIF models can be used to find an investment option that achieves an optimal relationship between the socioeconomic and financing components of individual digital health projects. They can also be used to find an optimal, sustainable balance of investment across projects identified in digital health strategies. The DHIF methodology enables support for both purposes.

To illustrate the approach, five illustrative case studies have been developed:

(i) digital surveillance, malaria;

(ii) SMS for pregnant women;

(iii) mHealth for telemedicine dermatology (no extra access for patients with no previous access, only for current patient cohorts);

(iv) $\mathrm{mHealth}$ for telemedicine dermatology (extra access for patient cohorts with no previous access; and

(v) Interoperable EHRs building on HIE.

These have been combined into an illustrative assessment of a digital health strategy. It shows how an overview can be used to test the strategy's VFM and affordability.

The features of each digital health investment are different in strategic fit to health and health care strategies, scale, scope, and socioeconomic returns. They all have a combination of digital health and direct health care resources, such as the resources needed to benefit from liberated capacity achieved by digital health. All estimates used in the models are for illustration only, as they are not taken from actual DHIF appraisals or evaluations. An example of the illustrative data from the five examples of DHIF models, providing a comparative strategic overview, is summarized in Table 3.

The five examples of DHIF models provide information to make digital health investment decisions. Each model uses illustrative data to show a positive socioeconomic return, which becomes negative when adjusted for risk exposure. None of them are shown as affordable. These features are examples of issues that DHIF models can reveal to refine investment plans in dialogues with stakeholders. Table 3 uses data from the five illustrative DHIF models to show how these themes can be identified.

Starting with affordability, each planned project has an affordability gap. Strategic options include a mix of:

(i) Find additional finance.

(ii) Find additional solutions, such as PPPs for EHRs, shown as leasing option in the EHRs model.

(iii) Cut projects from the strategic plan, such as the two mHealth telemedicine projects that have minimal and relative benefits, but also minimal relative costs, so they will not provide a substantial solution for the affordability challenge.

(iv) Cut the SMS and mHealth telemedicine + access projects because they carry the biggest risks.

(v) Cut the telemedicine projects because their scale is not big enough.

(vi) Expand the scale of the telemedicine projects and reduce other projects.

(vii) Design and apply an effective and rigorous risk mitigation strategy across all projects.

Each project requires considerable organizational costs. Decision-makers must ensure that realistic plans are in place to provide these resources, many of which are redeployed from existing budgets, sometimes from other agencies. Where this is not practical, the project should be reconsidered or scheduled for a possible cut to release funds for other projects. The malaria surveillance project has the lowest percentage organizational cost, reinforcing the decision to assign it as the top priority. 
Table 3: Comparison of Five Illustrative Digital Health Investment Models Over 10 Years

\begin{tabular}{|c|c|c|c|c|c|c|}
\hline \multirow{4}{*}{ DHIF Components } & \multicolumn{5}{|c|}{ All estimates are illustrative, not actual. } & \multirow{3}{*}{$\begin{array}{c}\text { Combined } \\
\text { Strategic }\end{array}$} \\
\hline & & mHealth & mHealth & Malaria & & \\
\hline & SMS & Telemedicine & Telemedicine & Telemedicine & EHRs & \\
\hline & & & with Access & & Capex & Program \\
\hline \multicolumn{7}{|c|}{ All Estimates are Illustrative Only } \\
\hline \multicolumn{7}{|c|}{ 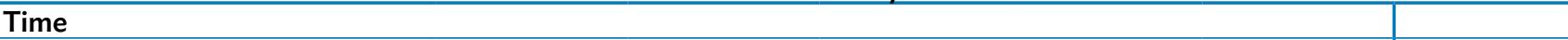 } \\
\hline Number of years & 6 & 6 & 6 & 6 & 10 & 10 \\
\hline Years to first annual SER & 3 & 3 & 3 & 3 & 5 & 5 \\
\hline Years to first cumulative SER & 3 & 3 & 3 & 3 & 5 & 5 \\
\hline Estimated cumulative SERs & $6596 \%$ & $399 \%$ & $492 \%$ & $430 \%$ & $780 \%$ & $782 \%$ \\
\hline $\begin{array}{l}\text { Estimated cumulative SERs } \\
\text { Adjusted for risk }\end{array}$ & $-78 \%$ & $-37 \%$ & $-56 \%$ & $-88 \%$ & $-71 \%$ & $-72 \%$ \\
\hline \multicolumn{7}{|l|}{ Benefits } \\
\hline Number of patients and carers & 36,000 & 36,250 & 40,197 & 34,129 & 300,000 & 446,576 \\
\hline Estimated lives saved & 3,631 & 0 & 0 & 13,651 & 0 & 17,282 \\
\hline Quality & $41.86 \%$ & $0.29 \%$ & $0.07 \%$ & $99.08 \%$ & $0.15 \%$ & $12 \%$ \\
\hline Access & $57.92 \%$ & $0.00 \%$ & $5.48 \%$ & $0.91 \%$ & $0.00 \%$ & $2 \%$ \\
\hline Efficiency & $0.23 \%$ & $99.71 \%$ & $94.45 \%$ & $0.02 \%$ & $99.85 \%$ & $86 \%$ \\
\hline Total & $100.00 \%$ & $100.00 \%$ & $100.00 \%$ & $100.00 \%$ & $100.00 \%$ & $100 \%$ \\
\hline Cash releasing & $0.00 \%$ & $0.06 \%$ & $0.04 \%$ & $0.00 \%$ & $0.09 \%$ & $0 \%$ \\
\hline Reployable resources & $0.07 \%$ & $99.65 \%$ & $99.89 \%$ & $0.02 \%$ & $99.66 \%$ & $86 \%$ \\
\hline Intangible & $99.92 \%$ & $0.29 \%$ & $0.07 \%$ & $99.98 \%$ & $0.25 \%$ & $14 \%$ \\
\hline Total & $100.00 \%$ & $100.00 \%$ & $100.00 \%$ & $100.00 \%$ & $100.00 \%$ & $100 \%$ \\
\hline \multicolumn{7}{|l|}{ Cost shares } \\
\hline Estimated cost per life saved & 6,599 & & & 105,602 & & 81,988 \\
\hline $\begin{array}{l}\text { Estimated cost per infection } \\
\text { Avoided }\end{array}$ & & & & 5,381 & & 5,381 \\
\hline Extra cash & $0.00 \%$ & $3.78 \%$ & $0.00 \%$ & $91.60 \%$ & $94.12 \%$ & $93 \%$ \\
\hline Redeployed resources & $73.46 \%$ & $96.12 \%$ & $0.00 \%$ & $8.35 \%$ & $5.75 \%$ & $7 \%$ \\
\hline Intangible & $17.85 \%$ & $0.09 \%$ & $0.00 \%$ & $0.05 \%$ & $0.13 \%$ & $0 \%$ \\
\hline Total & $100.00 \%$ & $100.00 \%$ & $0.00 \%$ & $100.00 \%$ & $100.00 \%$ & $100 \%$ \\
\hline \multicolumn{7}{|l|}{ Stakeholders } \\
\hline \multicolumn{7}{|l|}{ Benefits } \\
\hline Patients and citizens & $88.10 \%$ & $0.29 \%$ & $5.58 \%$ & $86.83 \%$ & $0.24 \%$ & $12 \%$ \\
\hline Health workers & $0.06 \%$ & $0.00 \%$ & $0.00 \%$ & $2.72 \%$ & $0.02 \%$ & $0 \%$ \\
\hline Health care provider Organizations & $11.84 \%$ & $99.71 \%$ & $94.42 \%$ & $10.46 \%$ & $99.74 \%$ & $88 \%$ \\
\hline Total & $100.00 \%$ & $100.00 \%$ & $100.00 \%$ & $100.00 \%$ & $100.00 \%$ & $100 \%$ \\
\hline \multicolumn{7}{|l|}{ Costs } \\
\hline Patients and citizens & $41.99 \%$ & $0.27 \%$ & $0.00 \%$ & $0.08 \%$ & $0.00 \%$ & $0 \%$ \\
\hline Health workers & $0.00 \%$ & $0.00 \%$ & $0.00 \%$ & $0.00 \%$ & $0.13 \%$ & $0 \%$ \\
\hline Health care provider Organizations & $58.01 \%$ & $99.73 \%$ & $0.00 \%$ & $99.92 \%$ & $99.87 \%$ & $100 \%$ \\
\hline Total & $100.00 \%$ & $100.00 \%$ & $0.00 \%$ & $100.00 \%$ & $100.00 \%$ & $100 \%$ \\
\hline \multicolumn{7}{|l|}{ ICT and Organisational Costs } \\
\hline $\mathrm{ICT}$ & $60.53 \%$ & $1.67 \%$ & $1.02 \%$ & $91.39 \%$ & $3.41 \%$ & $46 \%$ \\
\hline Organisational & $39.47 \%$ & $98.33 \%$ & $98.98 \%$ & $8.61 \%$ & $96.59 \%$ & $54 \%$ \\
\hline Total & $100.00 \%$ & $100.00 \%$ & $100.00 \%$ & $100.00 \%$ & $100.00 \%$ & $100 \%$ \\
\hline \multicolumn{7}{|l|}{ Finance and Affordability } \\
\hline Capital surplus or shortfall & $-28.35 \%$ & $-28.59 \%$ & $-28.59 \%$ & $-4.78 \%$ & $-43.35 \%$ & $-74 \%$ \\
\hline Annual surplus or shortfall & $-2.56 \%$ & $-32.34 \%$ & $-9.11 \%$ & $-256.60 \%$ & $-390.73 \%$ & $-291 \%$ \\
\hline
\end{tabular}

Capex = capital expenditure, $\mathrm{DHIF}=$ digital health impact framework, $\mathrm{EHR}=$ electronic health record, ICT = information and communication technology, SER = socioeconomic return, SMS = short message service.

Source: Authors. 
Strategic investment in foundation projects, such as unique patient identifiers and semantic interoperability, is not included in Table 3. In reality, they would be, and would show how each will contribute to the five projects. Foundation investment timings and costs can be factored into each of the five projects' estimated timescale, costs, benefits, and socioeconomic return.

These strategic perspectives then become part of the iteration process identified as step 10 in Figure 25. It helps to lock decisions about changing individual investment plans in digital health's strategic context and requirements. It is an essential perspective for digital health leaders.

Each of these models illustrates different aspects of digital health investments. They can be downloaded, saved, and adjusted to provide versions that enable A\&Es to be changed in order to show the effect of different A\&Es on the likely VFM of the investment (socioeconomic return), and health care organizations' financial ROI and affordability. All the A\&Es used are purely illustrative and not derived from specific programs or projects, but are rather intended to guide appraisals of actual potential investments.

Socioeconomic and financial challenges are different for small-scale digital health initiatives, such as SMS reminders to patients to take their drugs and for citizens to improve their families' hygiene. People can benefit directly, and digital health costs are not too complicated. Estimating the socioeconomic return-or the lack of it-and affordability is relatively straightforward, but still relies on estimates, knowledge, and the same broad approach to maximizing VFM, establishing affordability, and finding a viable solution.

Health care has a lower socioeconomic return because it carries most of the investment costs. Patients and caregivers carry very little, leading to considerable socioeconomic returns from improved health and health care as a result of the health systems digital health investment, its main strategic purpose.

An example of a socioeconomic return (from the SMS example) that reflects differences between their net benefits when adjusted for optimism bias is in Figure 26.

Not all digital health investments result in success. About $30 \%$ of public sector digital technology projects fail totally, and another 50\%-60\% are partial failures (World Bank 2016, p. 165). Challenges for

Figure 26: 5-Year Socioeconomic Return Net Benefits (Example)

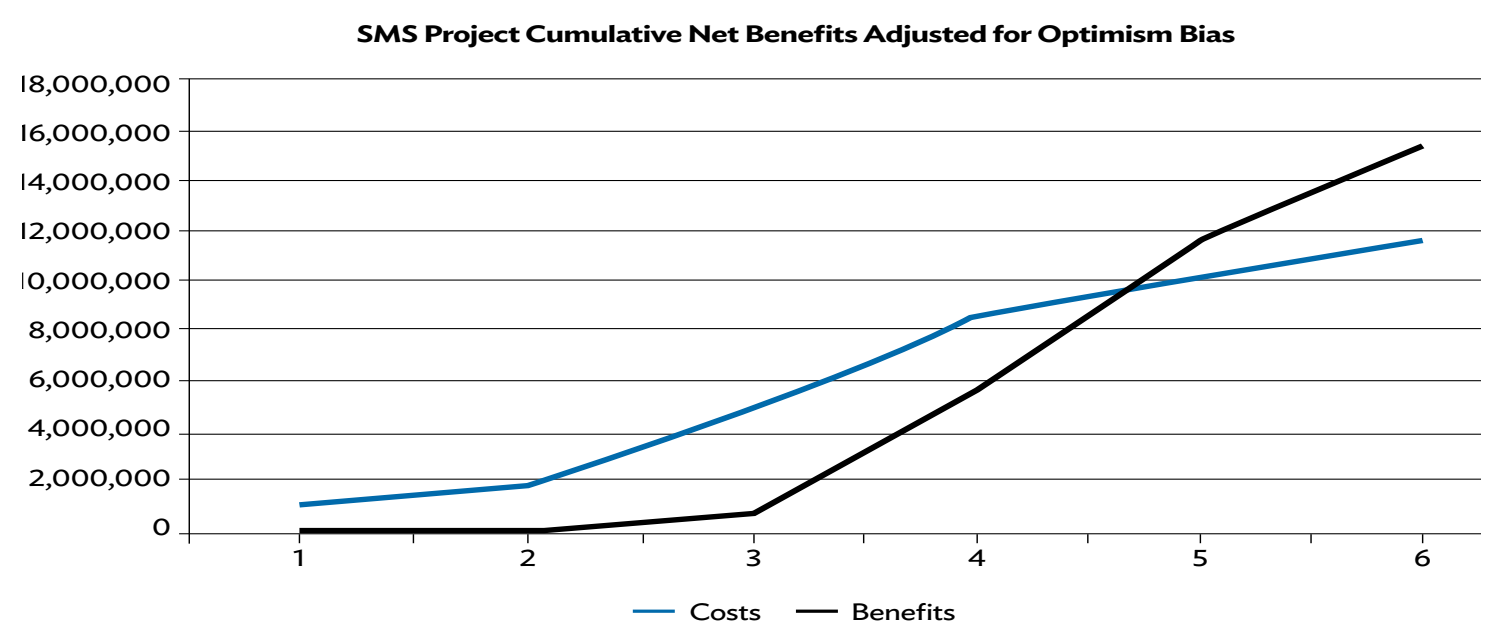

SMS = short message service.

Source: Authors. 
the digital health investment case include lack of evidence, emphasis on potential that exceeds probable results, and inadequate business cases.

The gap between the theory and the evidence of benefits of digital health technologies is large, and there is little research on the risks and cost-effectiveness. "In light of the paucity of evidence in relation to improvements in patient outcomes, as well as the lack of evidence on their cost-effectiveness, future digital health technologies should be evaluated against a comprehensive set of measures, ideally throughout all stages of the technology's life cycle. Such evaluation should be characterized by careful attention to socio-technical factors to maximize the likelihood of successful implementation and adoption." (Black 2011). There is also a psychological challenge. Five of Klein's (2014) 10 myths about the way people think and make decisions are:

(i) Generate several options, compare them, and pick the best.

(ii) A project starts with a clear goal.

(iii) At the end of a planning session, the team should critique the plan.

(iv) Diagnose a problem by trying to find its cause.

(v) Most organizations want to foster more insights.

These myths reinforce the need for rigorous digital health business cases and M\&E. They also identify a risk that some digital health business cases and socioeconomic and financial appraisals may be superficial.

Figure 27 is an example of the three curves of average socioeconomic returns from 36 evaluations (Jones 2014), mainly EHRs. It shows the difference between unsuccessful digital health and good digital health investments, particularly where there is additional socioeconomic return for high-level, interoperable solutions that offer additional third-party benefits, such as for research organizations:

The challenge is to ensure that projects avoid the bad curves and follow the good ones. Three important features of digital health investment curves are:

(i) All curves begin with $-100 \%$ socioeconomic returns, so decision-makers need to know which trajectory they are following.

Figure 27: Cumulative Socioeconomic Returns of 36 Digital Health Initiatives

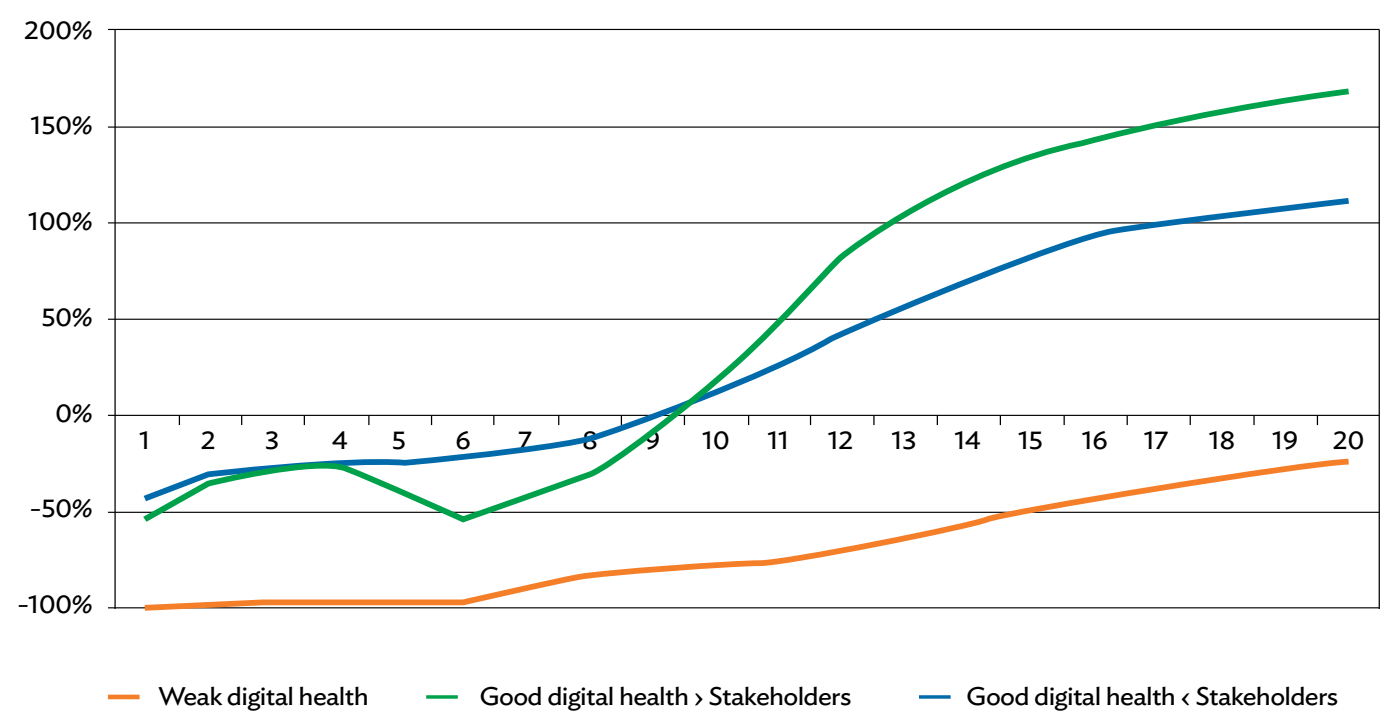

Source: Authors. 
(ii) Very soon after implementation, substantial benefits need realizing to achieve a steep and rising slope that sustains benefits into the longer term.

(iii) When digital health projects do not achieve this, and benefits are deferred, they may be unable to turn their net benefit curves toward success, requiring making tough decisions about their future.

Six important components of digital health that contribute to its success are:

(i) supporting priorities, goals, and objectives set out in health and health care strategies;

(ii) effective digital health leadership that results in successful and sustained stakeholder engagement and decision-making from the outset;

(iii) meeting user requirements and usability for substantial user utilization;

(iv) appropriate change management with a mix of process, organic, and strategic changes;

(v) sustainability, including financial and investment, in a wide range of human digital health capacity and capability; and.

(vi) effective risk mitigation.

\section{Requirements, Solutions, and Benefits}

The different requirements of each stakeholder type should each deliver a separate set of socioeconomic returns. These are assessed individually, then aggregated across stakeholders. As the number of connected stakeholders grows, so does the "network effect" that enables more net benefits to be derived (Kuratis 2009). The investment profile for the solution in question should reflect this. However, without having in place management and technical foundations such as a health worker registry and patient registries, these sorts of synergies - and their associated benefits, including cost savings-will not be realized.

In summary, there is a range of potential requirements for digital health investment, all of which require some supporting management and technical foundations. To meet them, key digital services such as networks, registers (of patients, health workers, and health facilities), knowledge support, and confidentiality and security will benefit all relevant stakeholders. While some stakeholders may pay and others benefit, overall improvements in efficiency, quality, and access together make a strong investment case. A selection of stakeholders' requirements to illustrate these general points is summarized in Table 4.

\section{Figure 28: Foundations for Cumulative Stakeholder Benefits and Better Socioeconomic Return}

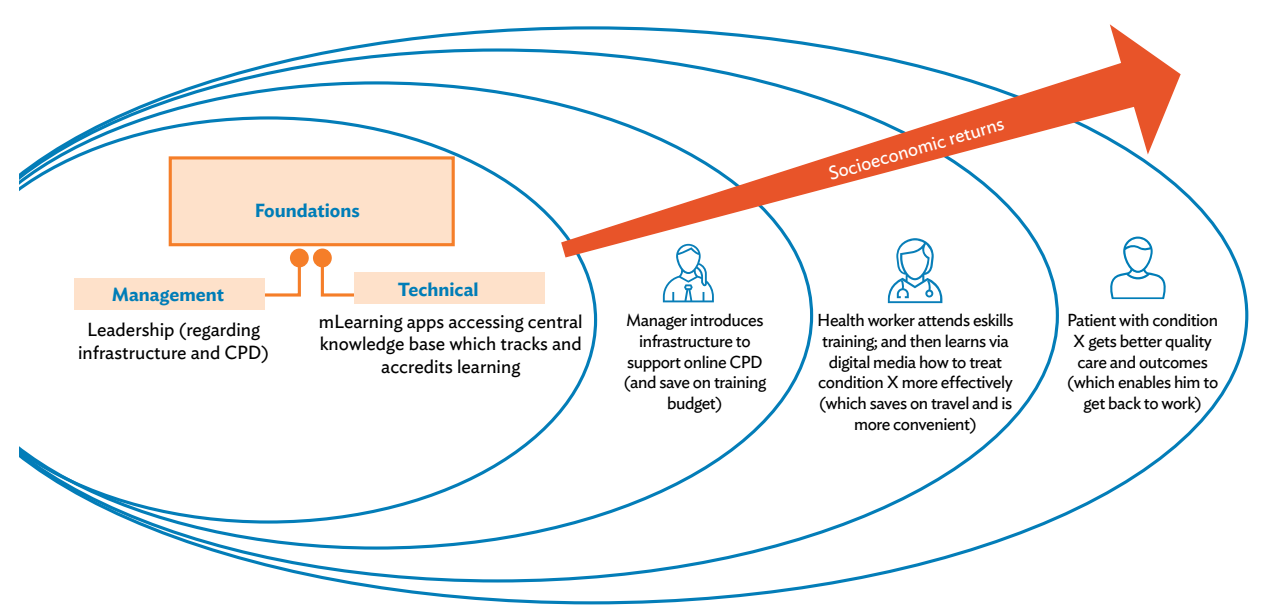

$\mathrm{CPD}=$ continuing professional development 


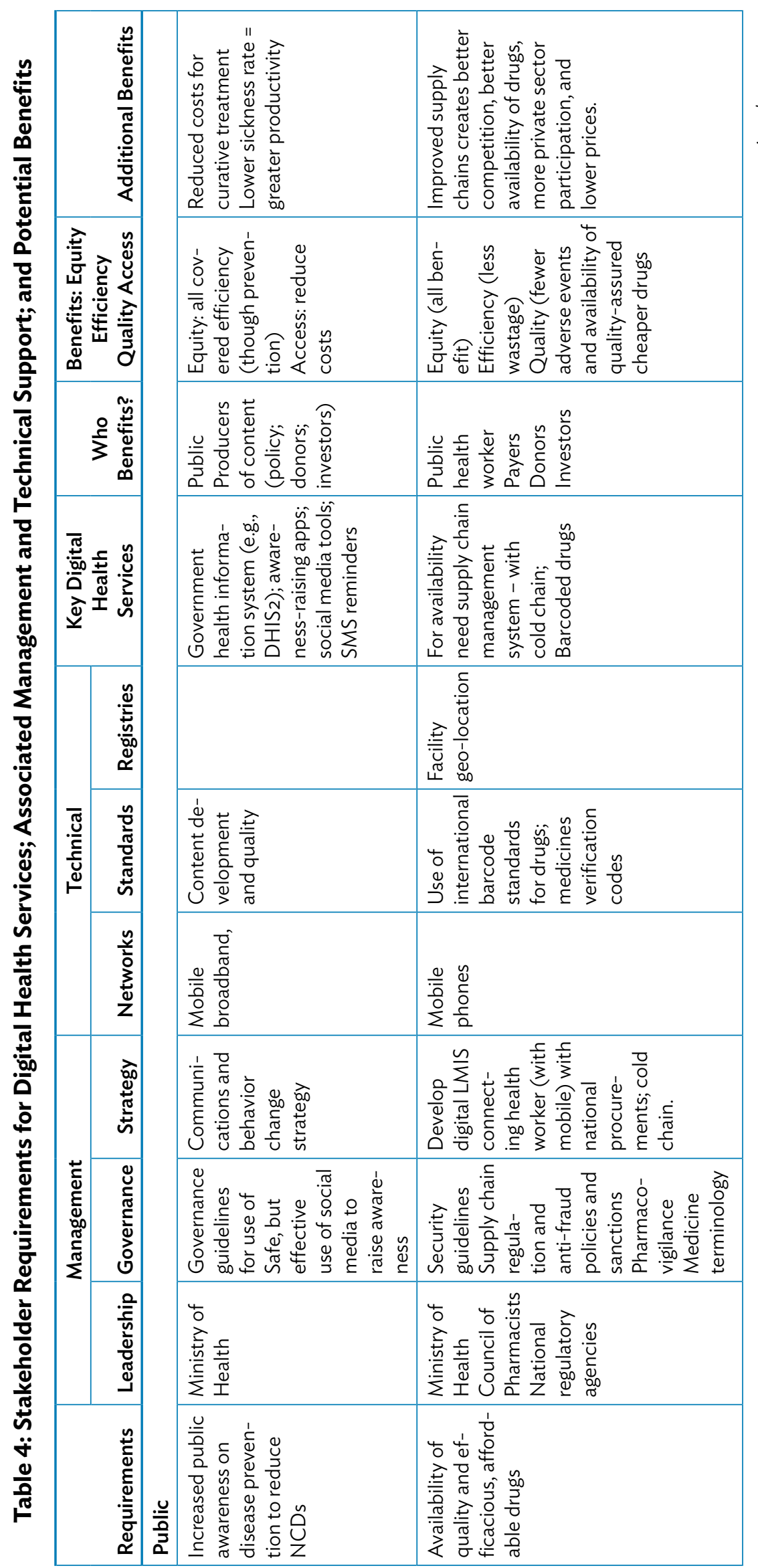




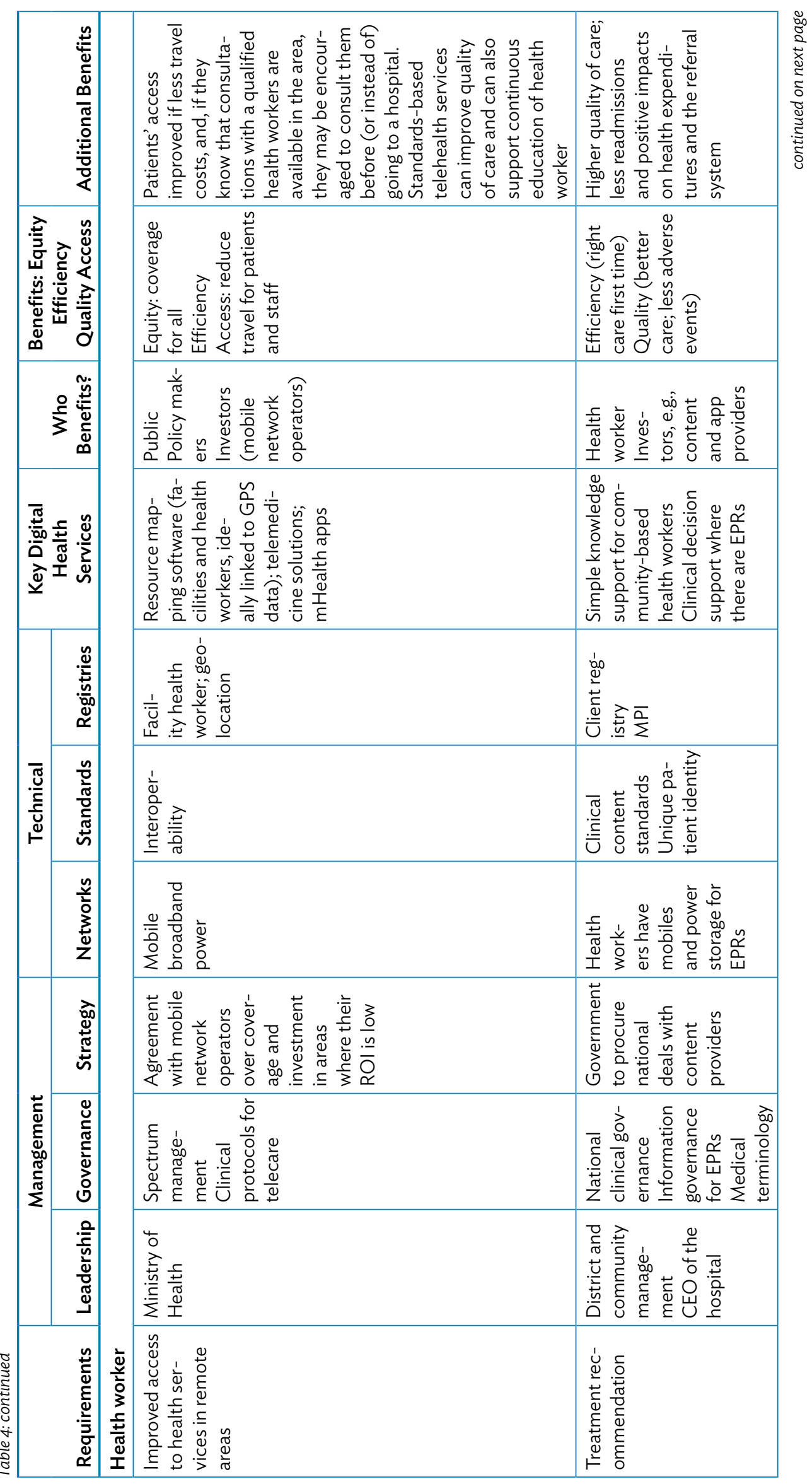




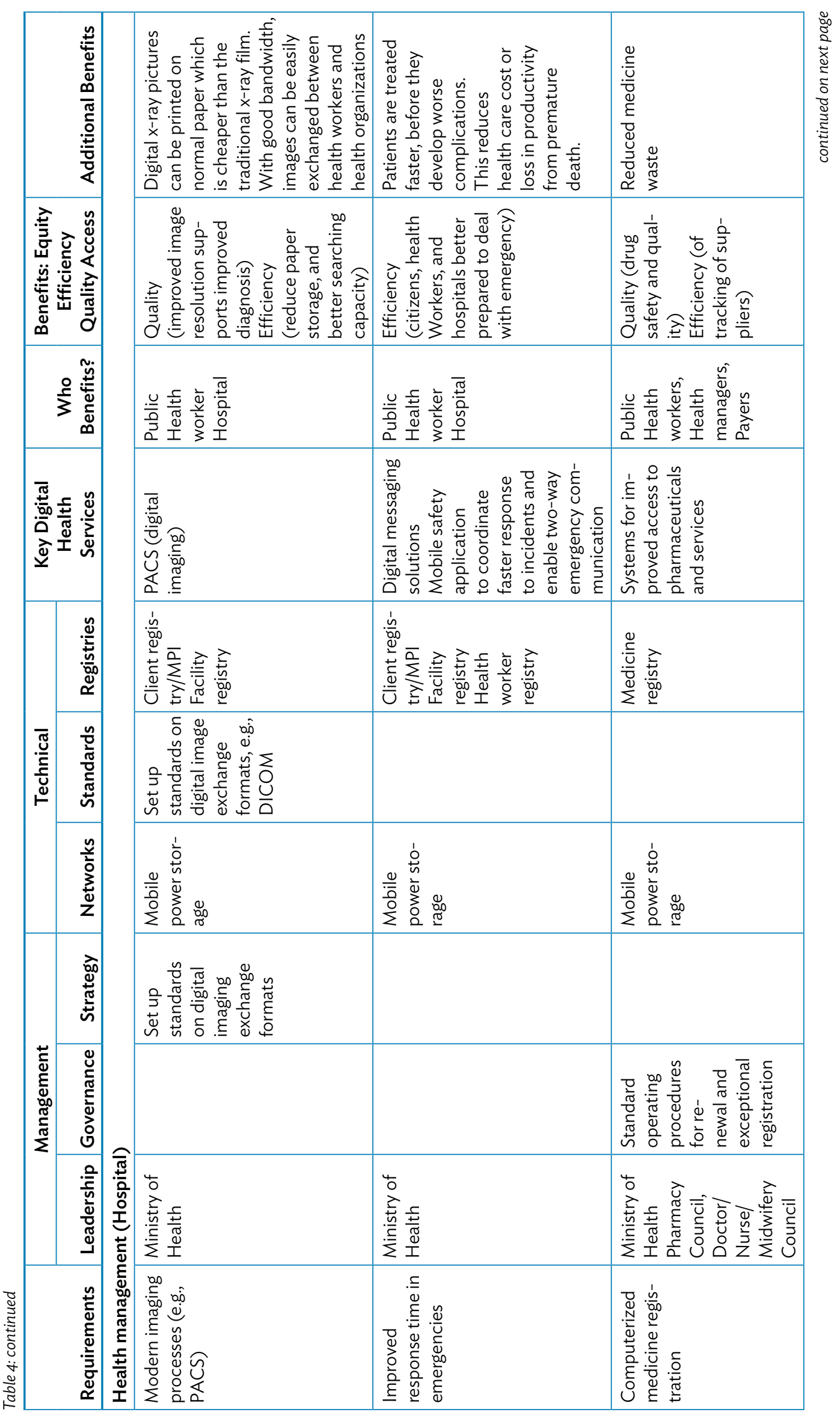




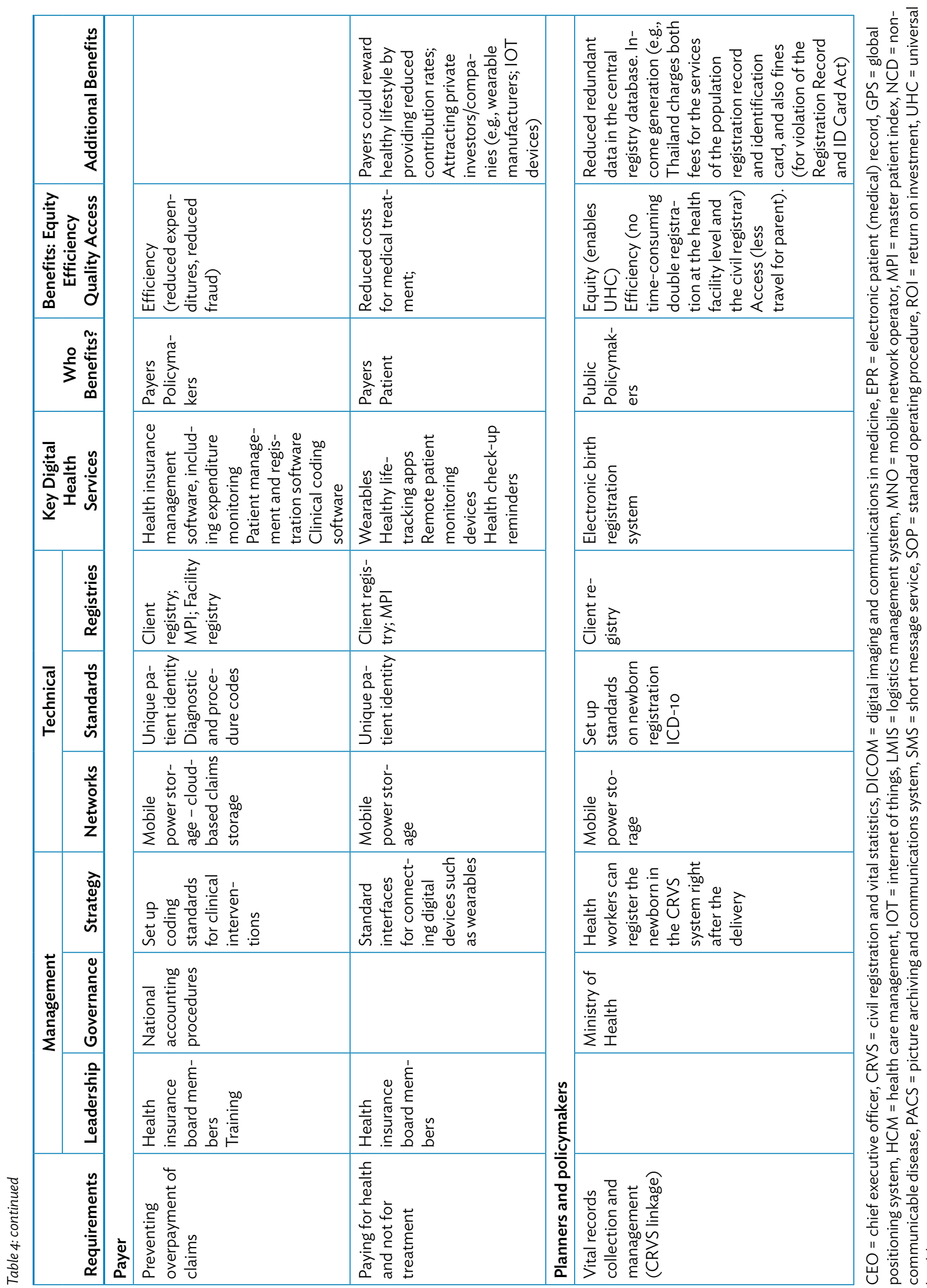




\section{FORWARD LOOK}

- The Sustainable Development Goals and universal health coverage frame the forward look in terms of policy. They require strengthening of health systems. The digital health perspective reinforces the importance of leveraging technology to support productivity and growth.

- An aging population and increasing non-communicable diseases will demand more patientcentered and connected care. Asia can leapfrog solutions from other countries.

- However, in the near future, there are some important barriers. These include digital (health) literacy of users, content, networks, access devices, and the need for governments and vendors to make sound investments.

- Health system goals should guide the implementation of technological innovations that the Fourth Industrial Revolution promises. We must manage the impact of digital health solutions on jobs, and expectations of what the technology can deliver (and by when).

The purpose of Chapter $V$ is to show how digital health can transform health systems. There are some near-term challenges to be addressed before the full potential of digital health technologies can be realized. "Rapidly changing technologies are already changing the nature of health services. New cadres of health workers are emerging, enabled by information and communication technologies ... the power of cost-effective information and communication technologies to enhance health education, peoplecentered health services and health information systems need to be properly harnessed" (High-Level Commission on Health, Employment and Economic Growth 2016, Chapter 2).

\section{A. Near Future: Challenges in Developing the Infrastructure}

A review of the challenges facing digital health has listed over 60 that are long-standing, and notes that "it's essential that countries and suppliers are clear about the challenges that need fixing for success and maximized benefits. While countries are often clear about the digital health challenges they face, it's vital the vendors are too" (African Centre for eHealth Excellence 2015).

Connectivity is a key challenge. While progress has been made in providing access to affordable internet (Alliance for Affordable Internet 2017), we need to make effective use of it. Smartphones for instance can be used for health-related purposes, such as to dispel rumors and false information about Ebola in Nigeria (West 2015); nearly $80 \%$ of responding countries in a recent WHO survey use social media to promote health messages and, in over $62 \%$ of countries, there are individuals and communities using social media to run community-based health campaigns (WHO 2016).

Even when there is affordable connectivity, ensuring digital health literacy (the ability to seek, find, understand, and appraise health information from electronic sources and apply the knowledge gained to addressing or solving a health problem) is paramount.

As summarized in Figure 29 (WEF/BCG 2015, p. 20), the multiple challenges limiting the adoption of digital services involve end users (literacy and cultural barriers), lack of content that would drive uptake in connectivity (because it is not in a local language, or only available on specific platforms, or is difficult to monetize for the provider), network challenges (access cost and complex pricing), and devices which are costly or difficult to support. 
These barriers are not health-specific, but health is well-placed to contribute to and draw on their resolution. For example, investment in digital health services-such as to create audiovisual content for citizens that conveys locally relevant health knowledge-can improve decision-making by public and patients, and open up new approaches to service delivery. At the local level, platforms and lowcost projectors can now support engaging knowledge with video content generated by communities for agriculture (Digital Green 2017), or using animations, to inform women's empowerment (Scientific Animations Without Borders 2017).

The blending of mobile phones, the internet, print-materials, television, and peer-to-peer learning when teaching languages (English in Action 2017), or the use of tablets for math (Pitchford 2015) are other examples from the education sector. These technologies and approaches now also inform the delivery of health and behavior change information (Global Health Media 2017, iHeed 2017, and Royston 2017). But are the potential synergies and benefits from these digital investments being fully considered? Can localized health content be developed within a local digital economy?

\section{Figure 29: Important Barriers to be Overcome in the Short Term}

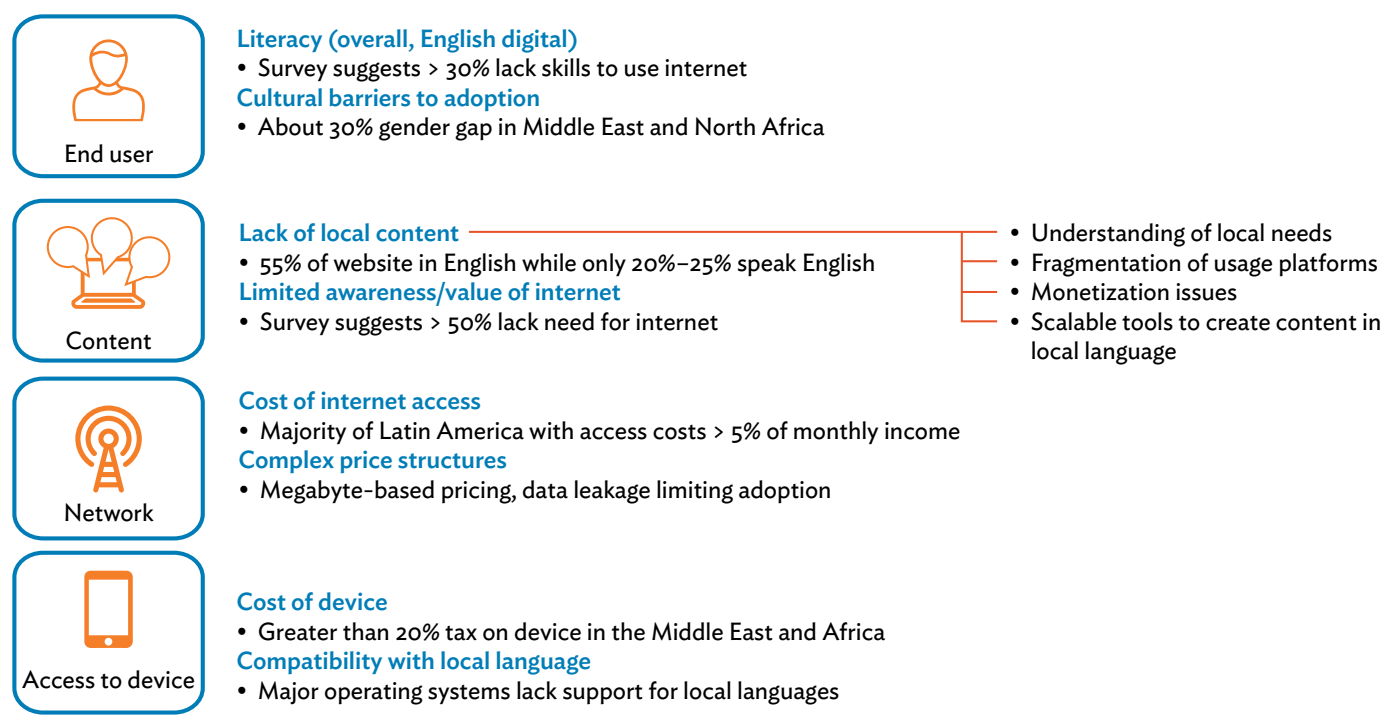

Source: World Economic Forum - Boston Consulting Group 2015.

Generating demand for content and connectivity helps the supplier community too. From their perspective, "venture-capital activity is limited and the private sector health care provision is at a low scale. Greater and more stable government investment in digital health-as opposed to cyclical/ individual initiatives - is key to help drive scale... (yet) digital health does not require high-tech solutions at this stage ... but the key challenge is the integration and interoperability among technologies" (Global System for Mobile Communications 2017).

If sound investment decisions address these barriers, then health systems can be improved with no one left behind. Governments have an important role to play, and we must likewise enable all stakeholders to make more effective investments in ICT by lowering the barriers illustrated in Figure 29. 


\section{B. Digital Technology}

The range and type of benefits from digital technologies have both expanded significantly over the last 5 years. They offer a source of data for health care to move toward personalized care (supported by patient cohort registries that health workers can use to be proactive in treating and caring for their patients) and precision medicine as digital support for genomics becomes more widespread. The current lodestone of digital health, EHRs, offers more benefits than just sharing clinical information within teams.

\section{Figure 30: Health Care Data Lake}

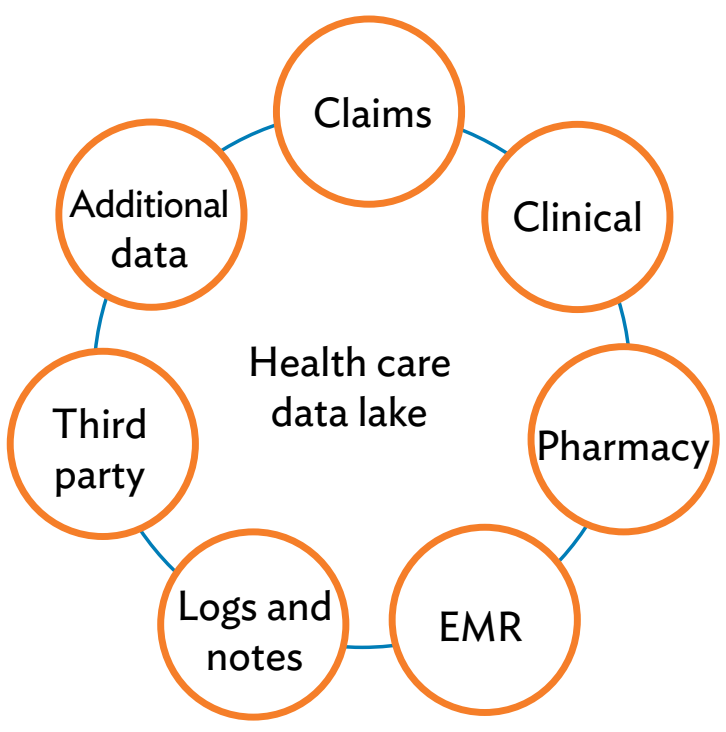

$E M R=$ electronic medical record.

Source: McDonald 2017.

Data may be stored in a "data lake" which enables "predictive analytics" to improve patient profile and outcomes (McDonald 2017), and create new benefits. An example is where predictive analytics and big data are creating new benefits, where EHRs provide one of the data sources needed to help detect type 2 diabetes without seeing patients (Anderson 2016). Another example is congestive heart failure: the earlier it is diagnosed, the better it can be treated, avoiding expensive complications, but early manifestations can be easily missed by physicians. A machine-learning example from Georgia Tech demonstrated that machine-learning algorithms could look at many more factors in patients' charts than doctors and, by adding additional features, there was a substantial increase in the ability of the model to distinguish people who have congestive heart failure from people who do not. "The system learns about you from your records to help health professionals precisely meet your personal needs." (Toon 2017). However, big data analytics tools have emerged in an ad hoc fashion mostly as opensource development tools, and lack the support and user-friendliness of vendor-driven proprietary tools (Raghupathi 2014). While we recognize the potential of big data, a recent survey suggests that less than a fifth of countries have a national policy or strategy regulating the use of big data in the health sector, and about $70 \%$ cite lack of integration, and privacy and security, as major barriers to adopting big data in support of UHC (WHO 2016). In assessing whether big data can improve health in low- and middleincome countries, Wyber et al. (2015) present both the "utopian" and the "dystopian" views: 
Table 5: Differing Views on the Big Data Approach

\begin{tabular}{|c|c|}
\hline Utopian & Dystopian \\
\hline $\begin{array}{l}\text { The big data era could represent a major and } \\
\text { beneficial turning point in the improvement of global } \\
\text { health. Decision-makers in low- and middle-income } \\
\text { countries could develop a "demand-side" platform to } \\
\text { identify the information they need most. Partnerships } \\
\text { formed with academia, industry, governments, international } \\
\text { organizations, and the nonprofit sector could help develop } \\
\text { innovative solutions. Although this idealized approach } \\
\text { is optimistic, it is no less ambitious than achieving the } \\
\text { Millennium Development Goals, eradicating polio, or } \\
\text { controlling malaria, and may help achieve these targets. }\end{array}$ & $\begin{array}{l}\text { In the worst-case scenario, big data would be an } \\
\text { expensive distraction driven by high-income countries, } \\
\text { focused on disease-specific outcomes. The assimilation } \\
\text { of fragmented data, which cannot be readily shared or } \\
\text { compared, could undermine the relatively fragile global } \\
\text { health community. Breaches of data security could threaten } \\
\text { personal safety, and lead to discrimination and genocide } \\
\text { and other violence. The global health community could } \\
\text { oversee the spending of huge amounts of money on big data, } \\
\text { with potentially little to show for the investment. }\end{array}$ \\
\hline - health data that are owned by patients; & $\begin{array}{l}\text { - diversion of focus and resources away from interventions } \\
\text { that are more needed; }\end{array}$ \\
\hline $\begin{array}{l}\text { robust governance processes that have been developed } \\
\text { to ensure respect of values and principles in the use of } \\
\text { data, with an emphasis on risk minimization; }\end{array}$ & $\begin{array}{l}\text { poor data governance, with databases held by private } \\
\text { companies, frequent leaks, and no recourse for citizens; }\end{array}$ \\
\hline $\begin{array}{l}\text { interoperability standards that allow data to be } \\
\text { seamlessly pooled and aggregated automatically, with } \\
\text { little effort and decreasing cost; }\end{array}$ & $\begin{array}{l}\text { offloading of consent through poorly designed consent } \\
\text { systems, which could threaten the safety of individuals; }\end{array}$ \\
\hline $\begin{array}{l}\text { - laws that, while establishing adequate safeguards, allow the } \\
\text { sharing and pooling of anonymized data in real time; and }\end{array}$ & $\begin{array}{l}\text { - a lack of interoperability, with siloed information systems } \\
\text { that cannot be aggregated; and }\end{array}$ \\
\hline $\begin{array}{l}\text { data that are presented in a usable format to patients, } \\
\text { health care providers, entrepreneurs, and policy-makers. }\end{array}$ & $\begin{array}{l}\text { - information that is poorly presented and analyzed, } \\
\text { considered illegible, or not credible. }\end{array}$ \\
\hline
\end{tabular}

Source: Wyber et al. 2015. Big data in global health: improving health in low and middle income countries. Bulletin of the World Health Organization 93:203208. Geneva: World Health Organization. doi:doi: http://dx.doi.org/10.2471/BLT.14.139022. In references.

As is becoming evident from one of the world's most advanced health information systems in Alberta, Canada (Murphy 2017), the secondary uses of data can add more value to decision-making about both population health and precision medicine for individuals. Indeed, electronic medical records provide only a small proportion of the data needed (Hinton 2016).

\section{Figure 31: Just Beginning: Digitalization of Health}

"EMR data represents $~ 8 \%$ of the data we need for population health and precision medicine" - Alberta Secondary Use Data Project

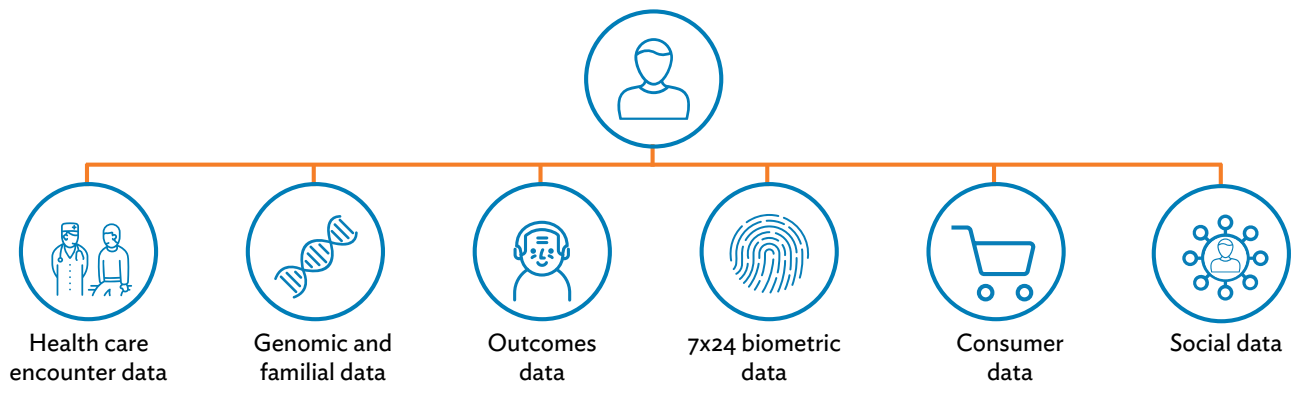

Growing Ecosystem of Human Health Data

$E M R=$ electronic medical record.

Source: Hinton 2016. 
These advances clearly rely on the exchange of information. In this realm, there are two new technologies that have transformative potential for the way health systems can function. Health Level 7 Fast Health Care Interoperability Resources (HL7 FHIR), for example, is a more granular way to exchange data without the rigid work flow of traditional HL7, enables vendors who connect medical devices, and supports mobile health applications and the cloud both to make money and to save money (Muir 2013). Blockchain also offers opportunities to reduce transaction costs, and enable distributed secure access to longitudinal health data about patients, using private and public identifiers secured through cryptography (Krawiec 2016).

These advances also rely on effective cybersecurity. But despite guidance on promoting cybersecurity in health care (US Department of Health and Human Services 2015), health systems seem ill-prepared to deal with cyberattacks. For example, the WannaCry ransomware attack in May 2017 resulted in 6,900 NHS appointments being cancelled because simple cybersecurity recommendations were not followed, according to the UK National Audit Office (Khalil 2017).

In summary, future health systems are expected to work with other sectors that impact on health, to provide UHC for all, and to do so in ways that are equitable; provide quality care; and are responsive, efficient, resilient, and affordable. That is how the health sector will contribute to the healthy years of life lived by people, and thereby help improve productivity and socioeconomic growth. Digital health systems can connect stakeholders in ways that can deliver other benefits such as:

(i) support for integrated, interoperable person-based systems;

(ii) assistance for people-centered care;

(iii) improved global and local public health surveillance, with a resultant reduction in epidemics, increased control over infectious disease and expanded drug safety;

(iv) diminished rate of medical errors;

(v) better "customer service" in health care;

(vi) ongoing preventive health, with attendant reductions in morbidity, mortality, and the cost of care;

(vii) consumer engagement in health and self-management; and

(viii) safer and more effective clinical trials.

The transformations envisaged by these initiatives are profound and complex. Properly conceived, and with the feedback loops and cross-sectoral implications made explicit within a digital health governance framework, successful investment in digital health can deliver considerable socioeconomic returns in improving health care, health, and development.

\section{Fourth Industrial Revolution and Health}

In 2016, the World Economic Forum considered the potential impact of the Fourth Industrial Revolution (4IR), marked by emerging technology breakthroughs in robotics, genomics, biosensors, and wearables, artificial intelligence, the internet of things (IOT), quantum computing, big data predictive analytics, 3D printing, additive manufacturing, advanced materials, and nanotechnology (Schwab 2016). The pace of change will only increase. As we look to the future, 4IR can transform health (Jimenez 2016) by:

(i) Embedding disease management in our daily lives. Devices could become more seamlessly interconnected through IOT to enhance patient monitoring, allowing individuals and their physicians to better manage conditions like non-communicable diseases. Sensors connected to IOT can engage non-communicable disease patients in their disease management, which could help reduce the incidence of adverse events and associated costs. 
(ii) Caring for the aging population with artificial intelligence. Robotics could provide some caregiving services to older individuals, such as continuous monitoring and assisting with tasks like keeping track of medicines. This is especially useful in areas with limited access to care, or where family caregivers are unable to attend to aging parents.

(iii) Genomics. Annotating, exploring, and analyzing gene sets that may be associated with cancer (Mutation Annotation \& Genome Interpretation 2017).

In medical devices, 4IR enables POC devices (right place, immediate answers), right-sizing (versus scale and growth), rapid manufacture of personalized prosthetics and products, personalized devices and technologies for precision medicine, and "this means it cannot be business as usual" (Bunn 2017). In his review of technology and the future of health care, Thrimbleby illustrates many of the technological drivers of health care in the future, but also stresses that "if we don't know what we need we will get what is easy and profitable to make" (Thrimbleby 2013, p. 167).

\section{Figure 32: Health System Goals for Implementation of Technological Innovation}
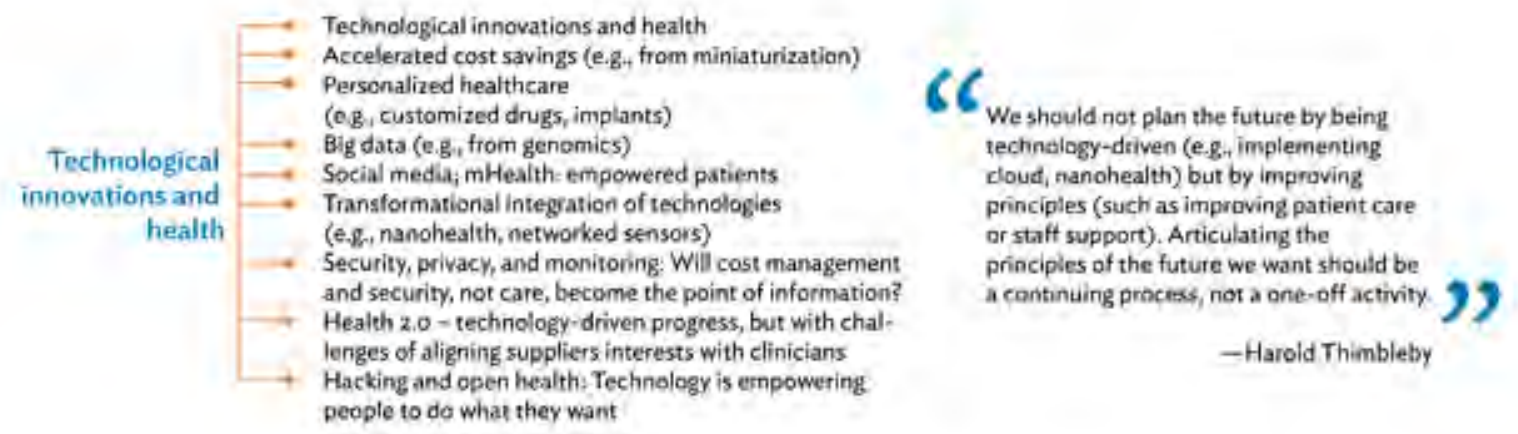

Source: Thrimbleby (2013).

It is also important to avoid the hype from suppliers and the tech community, and understand that the process of introducing innovations usually follows a "hype cycle" with five key phases (Gartner 2017). Digital health hype cycles are subjective, and a recent contribution (Price 2017) (Figure 30) indicates the range of new digital health technologies characteristic of the 4IR and the stages of the adoption process that they typically pass through (with expectations on the vertical axis and time on the horizontal). For example, HL7 FHIR and blockchain are just at the start of the hype cycle. This suggests that digital health investments should proceed with realistic expectations and an understanding of the diminishing returns as obsolescence grows over time.

Digital health investments should reflect the overall goals that the health system is trying to achieve, and the principles that guide them. Policy-makers need to understand the potential that technology can have on the working of the health system to figure out how best to frame their strategies for health and health care. 


\section{Figure 33: Expectations of What Can Be Delivered}

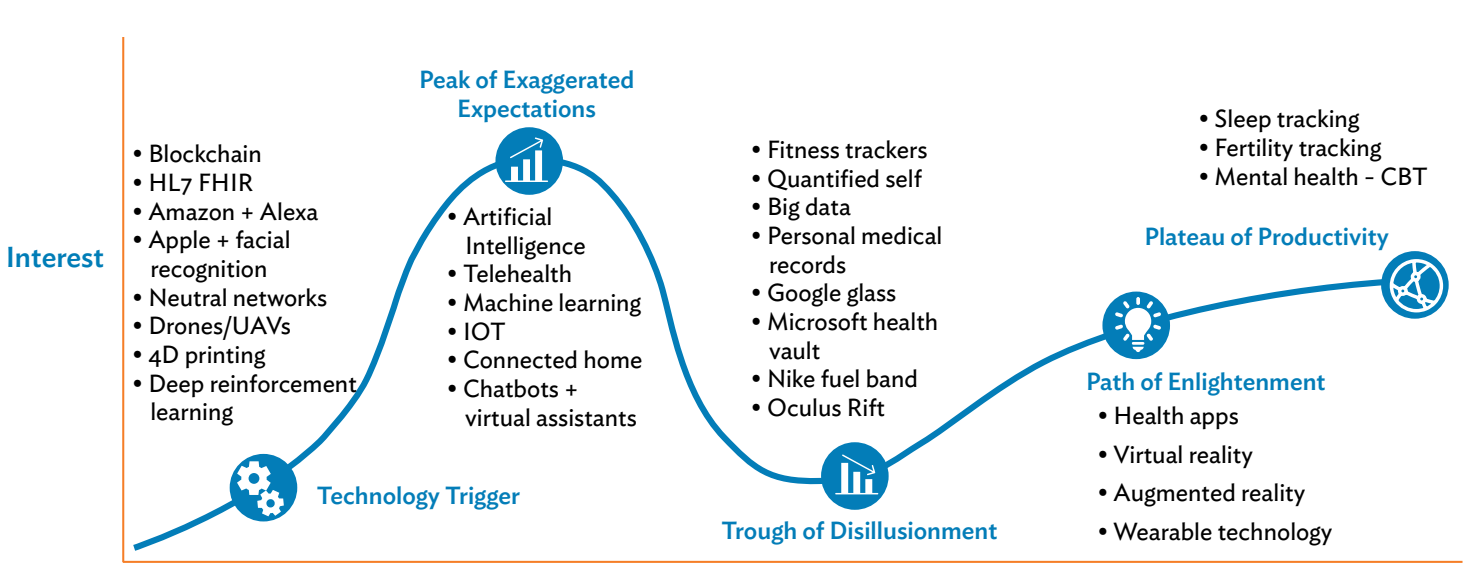

Time

CBT = cognitive behavioral therapy, HL7 FHIR = Health Level 7 Fast Health Care Interoperability Resources, ICT = information and communication technology, IOT = internet of things, UAV = unmanned aerial vehicle.

Source: Price (2017).

\section{Understanding the Impact of Technology on Jobs in the Health Sector}

Many fear that technology and automation will reduce the number of jobs available (Khosla 2012). This concern is not new, but the potential of the 4IR to decimate some jobs creates profound anxiety, particularly for middle-skilled professionals. "There's never been a worse time to be a worker with only 'ordinary' skills and abilities to offer, because computers, robots, and other digital technologies are acquiring these skills and abilities at an extraordinary rate" (Brynjolfsson 2014, p. 11). In the health sector, however, the impact may be reduced. For example, medical support occupations-such as radiology technicians, phlebotomists, and nurse technicians - are a significant and rapidly growing category of relatively well-remunerated employment that demands both technical and tacit skills (Autor 2015). The tacit skills of providing care to people are difficult to automate.

"The obstacles compromising technology's full potential to remedy the health workforce gap and improve health services include: lack of proper evaluation of what works and what does not (an obstacle to moving from pilots to full-scale implementation); lack of internet access and ICT infrastructure, costs of connectivity; lack of electricity supply, data insecurity, and restrictive regulatory frameworks. Other challenges include lack of ICT and digital technology knowledge and resistance to change among educators, health system managers, and health workers. Reaping the benefits of rapidly changing technologies will require internet/ICT infrastructure investments, especially in low- and middle-income countries" (High-Level Commission on Health, Employment and Economic Growth 2016, p. 41).

Digital health strategies that address these obstacles must adapt to new digital health technologies as they evolve, as well as the concomitant threats (cybersecurity, job insecurity). They need to be underpinned by policies that ensure that all solutions fit into a common architecture, and are standardized. Policies on data standards, governance, privacy, and security are required too, and, with them in place, the private sector and donors can also play a constructive role in a country's digital health ecosystem. 


\section{NEXT STEPS}

Often the benefits of digital health are not yet being realized because there are too many siloed solutions, compounded by poorly conceived projects or governance arrangements. The key is to ensure interoperability over a networked digital health infrastructure for integration of person- and peoplecentered health services (Appendix 1). The next steps are well known and explained by Health Data Collaborative (2017). The first steps, set out (in ADB 2018) are to:

(i) Define the digital health enterprise and identify all stakeholders.

(ii) Agree on what needs to be governed. Define the process for how decisions are being made on digital health strategy, investments, architecture, assets, standards, and applications.

(iii) Establish who governs and convenes all agencies and entities holding key resources, such as ministries responsible for ICT and for statistics, health insurance providers, and private sector supporters into a national digital steering committee or similar body.

(iv) Adopt a digital health governance framework. Define levels of governance to be executed at central and subnational levels depending on the decentralization and public-private health care provider mix of the country.

(v) Identify performance measures and monitoring processes for the adopted framework to ensure accountability and promote the improvement of the health system toward patient-centric and integrated care.

(vi) Revisit, update, and keep the governance framework active according to changing requirements of the digital health enterprise with advancing technological adoption.

There are also generic requirements for improvements in:

(i) levels of efficiency of investments in health information;

(ii) effectiveness of program management;

(iii) standardized data management processes and data ownership mechanisms;

(iv) access to and use of data, statistics, analytics, visualization, and research at all levels of the health care system for better data use and health systems performance;

(v) identity management, including birth registration and improving CRVS;

(vi) establishment of health data dictionaries that contain all the necessary data elements and standards for health information (such as for diseases, messaging standards, facilities), and offer interoperability testing (via interoperability labs);

(vii) working with the MNOs and ICT suppliers for a digital infrastructure that ensures every citizen has access to affordable connectivity, engaging health content and person-centered services when and where appropriate (from home to hospital);

(viii) using a consistent, standard economic and financial evaluation framework to enable comparisons and compile a library to inform future digital investment; and

(ix) networking with stakeholders for sharing of information that goes beyond basic governance.

But what is also needed is progress in understanding how best to support stakeholder investment and implementation to ensure success. For example:

(i) For the public: engage knowledge support that makes a phone worth investing in.

(ii) For health workers: decision and service support, with management data produced as a by-product, and mobile devices that support this, with the additional benefits of online learning and training. Prioritize tools that reduce the data entry burden.

(iii) For health managers: provide guidance on procurement of digital health solutions, and how to nurture a data use culture that values both use of standards and resulting information. 
(iv) For payers: facilitate exchange of payment and performance information with providers.

(v) For investors and donors: encourage shift from disease silos to health systems, removing barriers to investment while improving information governance arrangements.

(vi) For planners and policymakers: M\&E systems and associated surveys, research and development to nurture the innovations that enable digital health to also support development.

To address this agenda and figure out what to do next, each country will need to assess its own situation and build an investment road map. This requires leadership and expertise in understanding the digital health agenda and opportunities.

Countries should have their own health strategies and associated digital health strategies (or eHealth strategies), and many may have an eGovernment strategy, all of which will help give the strategic context for the application of making a digital health investment. There are toolkits available for countries to use, like the costing tool for key infrastructure components (Standards and Interoperability Lab for Asia 2017).

Some of the first steps that may be needed are illustrated in Figure 34, showing (over 10 time periods, which will vary), a sequence of steps to work through. Different countries may be at different steps on the pathway toward developing sound investments in digital health. But the steps in Figure 34 (and relevant toolkits [Appendix 3]) illustrate how different aspects of the foundational investments in digital health are needed to support some early (and affordable) deliverables to key stakeholders. Each of them needs investment.

The outcome of the use of this guidance should be a plan with a timeline, benefits, system components, processes, policies, and costing information on what is planned for implementation, as well as gaps identified and how to address them. 
Figure 34: First steps

\begin{tabular}{|c|c|c|c|c|c|c|}
\hline Time Period & 1 & 2 & 3 & 4 & 5 & 6 \\
\hline $\begin{array}{l}\text { Strategy and } \\
\text { investment }\end{array}$ & & $\begin{array}{l}\text { Strategy } \\
\text { development }\end{array}$ & $\begin{array}{l}\text { Situation } \\
\text { analysis }\end{array}$ & $\begin{array}{l}\text { Strategy } \\
\text { development }\end{array}$ & $\begin{array}{l}\text { Investment } \\
\text { plan } \\
\text { Investment } \\
\text { profiles }\end{array}$ & \\
\hline $\begin{array}{l}\text { Leadership and } \\
\text { governance }\end{array}$ & $\begin{array}{l}\text { Senior } \\
\text { government } \\
\text { leadership. } \\
\text { SDG; 2030; } \\
\text { health strategy; } \\
\text { UHC }\end{array}$ & Governance & & & & $\begin{array}{l}\text { Implementation } \\
\text { plan }\end{array}$ \\
\hline $\begin{array}{l}\text { Digital health } \\
\text { skills for } \\
\text { workforce }\end{array}$ & & lealth & & & & \\
\hline
\end{tabular}

\begin{tabular}{|c|c|c|c|c|}
\hline Time Period & 7 & 8 & 9 & 10 \\
\hline $\begin{array}{l}\text { Legislation } \\
\text { policy and } \\
\text { compliance }\end{array}$ & $\begin{array}{l}\text { Use of } \\
\text { eGovernment } \\
\text { content }\end{array}$ & . & & $\begin{array}{l}\text { Confidentiality } \\
\text { and privacy } \\
\text { policy }\end{array}$ \\
\hline $\begin{array}{l}\text { Services and } \\
\text { applications }\end{array}$ & $\begin{array}{l}\text { Health } \\
\text { information } \\
\text { content } \\
\text { development for } \\
\text { public }\end{array}$ & $\begin{array}{l}\text { RMNCH } \\
\text { Knowledge } \\
\text { support for } \\
\text { health workers }\end{array}$ & $\begin{array}{l}\text { Ordering of } \\
\text { Supplies and } \\
\text { services }\end{array}$ & $\begin{array}{l}\text { Identity } \\
\text { management } \\
\text { of patients } \\
\text { and health } \\
\text { workers }\end{array}$ \\
\hline $\begin{array}{l}\text { Standards and } \\
\text { interoperability }\end{array}$ & & & $\begin{array}{l}\text { Codes and } \\
\text { messaging drugs } \\
\text { and other supplies }\end{array}$ & \\
\hline Infrastructure & $\begin{array}{l}\text { Basic, then smart } \\
\text { mobile phones \& } \\
\text { Mobile BB } \\
\text { Power }\end{array}$ & $\begin{array}{c}\text { Closing } \\
\text { the access } \\
\text { gap }\end{array}$ & $\begin{array}{l}\text { BB network for } \\
\text { logistics } \\
\text { Storage }\end{array}$ & $\begin{array}{l}\text { Registries and } \\
\text { authentication }\end{array}$ \\
\hline $\begin{array}{l}\text { Digital health } \\
\text { skills for } \\
\text { workforce }\end{array}$ & & $\begin{array}{l}\text { Skills support } \\
\text { for use of } \\
\text { knowledge } \\
\text { support }\end{array}$ & $\begin{array}{l}\text { Logistics } \\
\text { management } \\
\text { training }\end{array}$ & $\begin{array}{l}\text { Identity } \\
\text { management } \\
\text { training }\end{array}$ \\
\hline
\end{tabular}

AeHIN = Asia eHealth Information Network, DHIF = digital health impact framework, HIGAF = health ICT (information and communication technology) governance architecture framework, RMNCH = reproductive, maternal, newborn and child health, $\mathrm{SDG}=$ Sustainable Development Goal, $\mathrm{UHC}=$ universal health coverage, $\mathrm{WHO}=$ World Health Organization. 


\section{APPENDIX 1: KEY DEFINITIONS}

\begin{tabular}{|c|c|c|}
\hline Term & Definition & Source \\
\hline eHealth & $\begin{array}{l}\text { eHealth is the cost-effective and secure } \\
\text { use of ICT in support of health and health- } \\
\text { related fields, including health care services, } \\
\text { health surveillance, health literature, health } \\
\text { education, and knowledge and research. }\end{array}$ & $\begin{array}{l}\text { World Health Assembly } 2005 \text { resolution 58.28. } \\
\text { However, another review gave } 51 \text { different } \\
\text { definitions of the term (Oh, 2005) }\end{array}$ \\
\hline Digital health & $\begin{array}{l}\text { Digital health and eHealth are used as } \\
\text { umbrella terms to encompass all concepts } \\
\text { and activities at the intersection of health } \\
\text { and ICTs, including mobile health (mHealth), } \\
\text { health information technology, electronic } \\
\text { health records, and telehealth }\end{array}$ & $\begin{array}{l}\text { Broadband Commission for Sustainable } \\
\text { Development: (2017). Digital Health: A Call for } \\
\text { Government Leadership and Cooperation } \\
\text { between ICT and Health }\end{array}$ \\
\hline Health system & $\begin{array}{l}\text { A health system's many parts operate at many } \\
\text { levels. Smaller systems may be self-contained } \\
\text { and have limited scale and scope, such as } \\
\text { those involved in running a clinic or managing } \\
\text { a health information system. Larger systems } \\
\text { might involve the coming together of various } \\
\text { smaller systems, e.g., clinics, hospitals, and } \\
\text { health-promotion programs, to provide } \\
\text { coherence at community or national level. }\end{array}$ & $\begin{array}{l}\text { World Bank: (2007). } \\
\text { Healthy development: World Bank strategy for } \\
\text { health, nutrition, and population results }\end{array}$ \\
\hline Digital health system & $\begin{array}{l}\text { The interrelated set of technologies, } \\
\text { processes, and structures within a digital } \\
\text { health ecosystem, typically encompassing } \\
\text { numerous individual solutions and } \\
\text { organizations. }\end{array}$ & $\begin{array}{l}\text { Broadband Commission for Sustainable } \\
\text { Development (2017). Digital Health: A Call } \\
\text { for Government Leadership and Cooperation } \\
\text { between ICT and Health }\end{array}$ \\
\hline Integrated health services & $\begin{array}{l}\text { Health services that are managed and } \\
\text { delivered so that people receive a continuum } \\
\text { of health promotion, disease prevention, } \\
\text { diagnosis, treatment, disease-management, } \\
\text { rehabilitation, and palliative care services, } \\
\text { coordinated across the different levels } \\
\text { and sites of care within and beyond the } \\
\text { health sector, and according to their needs } \\
\text { throughout the life course. }\end{array}$ & $\begin{array}{l}\text { Framework on integrated, people-centered } \\
\text { health services. WHO A69/39 (2016) http:// } \\
\text { apps.who.int/gb/ebwha/pdf_files/WHA69/ } \\
\text { A69_39-en.pdf?ua=1 }\end{array}$ \\
\hline People-centered care & $\begin{array}{l}\text { An approach to care that consciously adopts } \\
\text { perspectives of individuals, carers, families, } \\
\text { and communities as participants in, and } \\
\text { beneficiaries of, trusted health systems that are } \\
\text { organized around the comprehensive needs } \\
\text { of people rather than individual diseases, and } \\
\text { respects social preferences. People-centered } \\
\text { care also requires that patients have the } \\
\text { education and support they need to make } \\
\text { decisions and participate in their own care, and } \\
\text { that carers are able to attain maximal function } \\
\text { within a supportive working environment. } \\
\text { People-centered care is broader than patient } \\
\text { and person-centered care, encompassing not } \\
\text { only clinical encounters, but also including } \\
\text { attention to the health of people in their } \\
\text { communities and their crucial role in shaping } \\
\text { health policy and health services. }\end{array}$ & $\begin{array}{l}\text { Framework on integrated, people-centered } \\
\text { health services. WHO A69/39 (2016) http:// } \\
\text { apps.who.int/gb/ebwha/pdf_files/WHA69/ } \\
\text { A69-39-en.pdf?ua=1 }\end{array}$ \\
\hline
\end{tabular}

ICT = information and communication technology, WHO = World Health Organization.

Source: Authors. 


\section{APPENDIX 2: DIGITAL HEALTH IMPACT FRAMEWORK}

Governments should invest in helping stakeholders make the best use of their investments in digital health. In making an investment case, the key questions for each of the stakeholders involved to consider are:

1. What is the social and political context? Is there the will and finance to pursue a good case through to implementation?

2. What are the options, including possible public-private partnerships?

3. Do the options fit with health, health care, and eHealth strategies?

4. What are the intended and probable results, and how long will it take to realize them?

5. What are the priority investments intended, what is their cost, and how do they help achieve the intended and probable results? This stage can make use of modeling tools for assessing cost and benefits over time, and should address

(i) how and when will benefits be realized;

(ii) required results of the preferred option that has highest priority to be achieved;

(iii) estimated costs and benefits for each stakeholder type;

(iv) estimated monetary values of the benefits;

(v) socioeconomic returns for each option and their adjustments for sensitivity, optimism bias, and risk exposure;

(vi) how risks will be mitigated;

(vii) how and where services will be delivered;

(viii) focus of services; and

(ix) life cycles, affordability of options.

6. What are the priority actions within the resources available?

7. How will the results be monitored and evaluated?

In building the case for investment (HM Treasury 2015), it will be important to show that:

(i) The proposed initiative is needed and fits well with other relevant strategies.

(ii) It represents value for money.

(iii) It is commercially viable.

(iv) The main investors, who may not be the direct beneficiaries, can afford it.

(v) It is achievable.

Mechanisms also need to be in place to monitor and improve performance.

The consistent methodology of digital health impact framework (DHIF) provides an appraisal of estimated costs, benefits, net benefits, the socioeconomic returns, and financial affordability over time of individual digital health projects. It enables bespoke appraisals that can be aggregated to help leaders and planners to:

(i) understand and develop the socioeconomic and financial aspects of their digital health strategies, and modify them as needed, and

(ii) make informed investment decisions for sustainable digital health programs and projects.

DHIF is a proven methodology used in over 60 evaluations. It starts by setting a timeline that broadly matches an investment's life cycle. Then, assumptions and estimates of types of users and stakeholders can be prepared for each year. DHIF should include estimated changes arising from digital health 
projects, such as healthier citizens and communities and more appropriate health care utilization. These arise from digital health's impact on patients, carers and citizens, health workers, and health care organizations.

\section{Socioeconomic Benefits}

These benefits are grouped into three main types, culminating in strengthened health systems.

\section{Quality}

(i) Better-informed patients;

(ii) safer health care;

(iii) shorter waiting times;

(iv) integrated health care; and

(v) more effective health care, including lives saved and illness prevented.

\section{Access}

Citizens that could not access health care now can (with an improvement in equity).

\section{Efficiency}

(i) Cash releasing savings, and

(ii) improved productivity leading to redeployable resources.

Monetary values can be assigned to intangible benefits such as lives saved, illness prevented, time savings, and improved health care quality. This relies on data for changes to health care costs where resources can be liberated by digital health. We may need to include the increased costs for patients who need more health care, such as citizens previously unable to access services. For citizens and patients, affordability (including travel time and cost to access services) can be crucial for benefits realization, so investment decisions must reflect this.

\section{Socioeconomic Costs}

(i) Extra resources needed. Drugs, medical and surgical supplies, increased patients' travel, mobile devices and services, computer and network capacity, software, middleware, databases, data warehouses, project managers, trainers, computer support teams, health analytics teams, and obsolescence.

(ii) Resources redeployed from other activities. Doctors, nurses, and pharmacists allocating time for engagement, training events, change management, and benefits realization.

(iii) Intangible resources. For instance, increased patients' travel time.

Socioeconomic costs reflect monetary values of resources. They include donated equipment and other resources, but exclude transfer payments where no resources are involved, such as unrecoverable value added tax, grants, cash donations, depreciation, and health care organizations' loan repayments.

\section{Financial Costs}

There are two types of financial costs in investment appraisal: cash flow, and income and expenditure (using accruals methodology). They include transfer payments, grants, donations, depreciation, and loan repayments. Also included for comparison are annual capital expenditure and operational expenditure budgets and provisions in financial plans. 
The main cost estimates for health care organizations are for information and communication technology capital and operational expenditure. Operational expenditure includes resources redeployed from existing budgets, such as doctors' and other health workers' time allocated to digital health engagement and away from clinical activities. All cost estimates are increased for contingencies, reflecting the limitations of using estimates at early stages of projects when some cost components may not be known or fully understood.

There are important distinctions for large-scale digital health (such as electronic health records [EHRs]) and their foundation investments. Also, we need to compare the financial implications of public-private partnerships (PPPs) with conventional capital expenditure options to ensure financial viability. For health care, they face a switch from capital to operational expenditure, usually including leasing, with PPP. The resulting socioeconomic return and affordability both need rigorous appraisal, starting early in the decision process.

\section{Testing}

All costs and benefits are tested for sensitivity (potential changes to interest rates, costs, and/or other variables), optimism bias (to counter typical underestimation of costs and overestimation of benefits) and risk exposure (the probability of different incidents occurring multiplied by potential losses).

\section{Examples}

Two examples of the results are the gross costs and benefits of an illustrative project for EHRs, and the estimates adjusted for risk exposure.

\section{Figure A2.1: Electronic Health Records Capital Expenditure Annual Cost and Benefits}

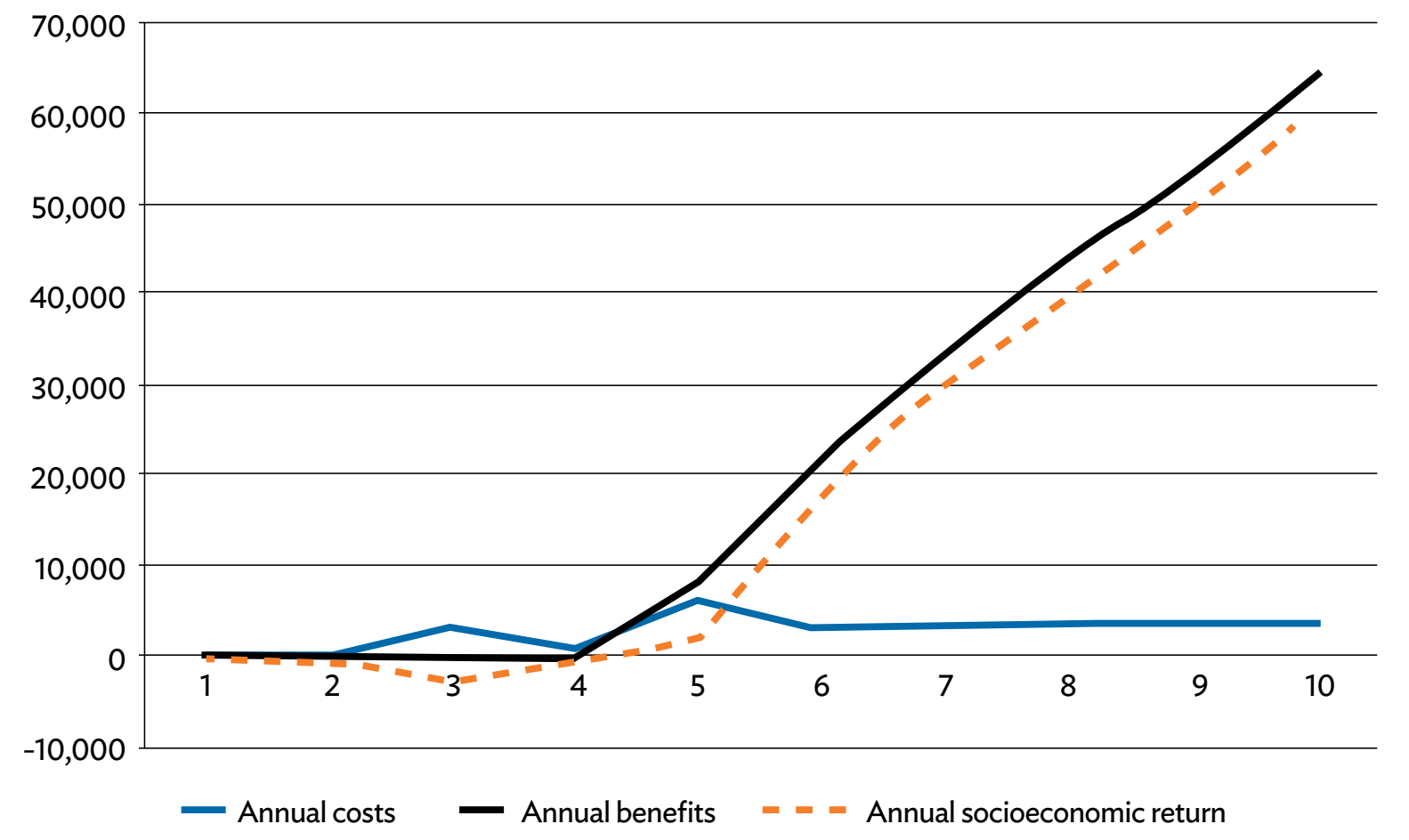


These gross cost and benefit curves show a strong socioeconomic return, the dashed curve. The position reverses when these are adjusted for risk exposure, indicating a probable scale of a socioeconomic deficit if risks are not mitigated effectively. When a risk mitigation plan is in place, the risk exposure can be reset to test its impact. This is vital information for PPPs where some risks are often shared, but may not be shared sustainably.

Figure A2.2: Electronic Health Records Cumulative eHealth Information Risk-Adjusted Capital Expenditure

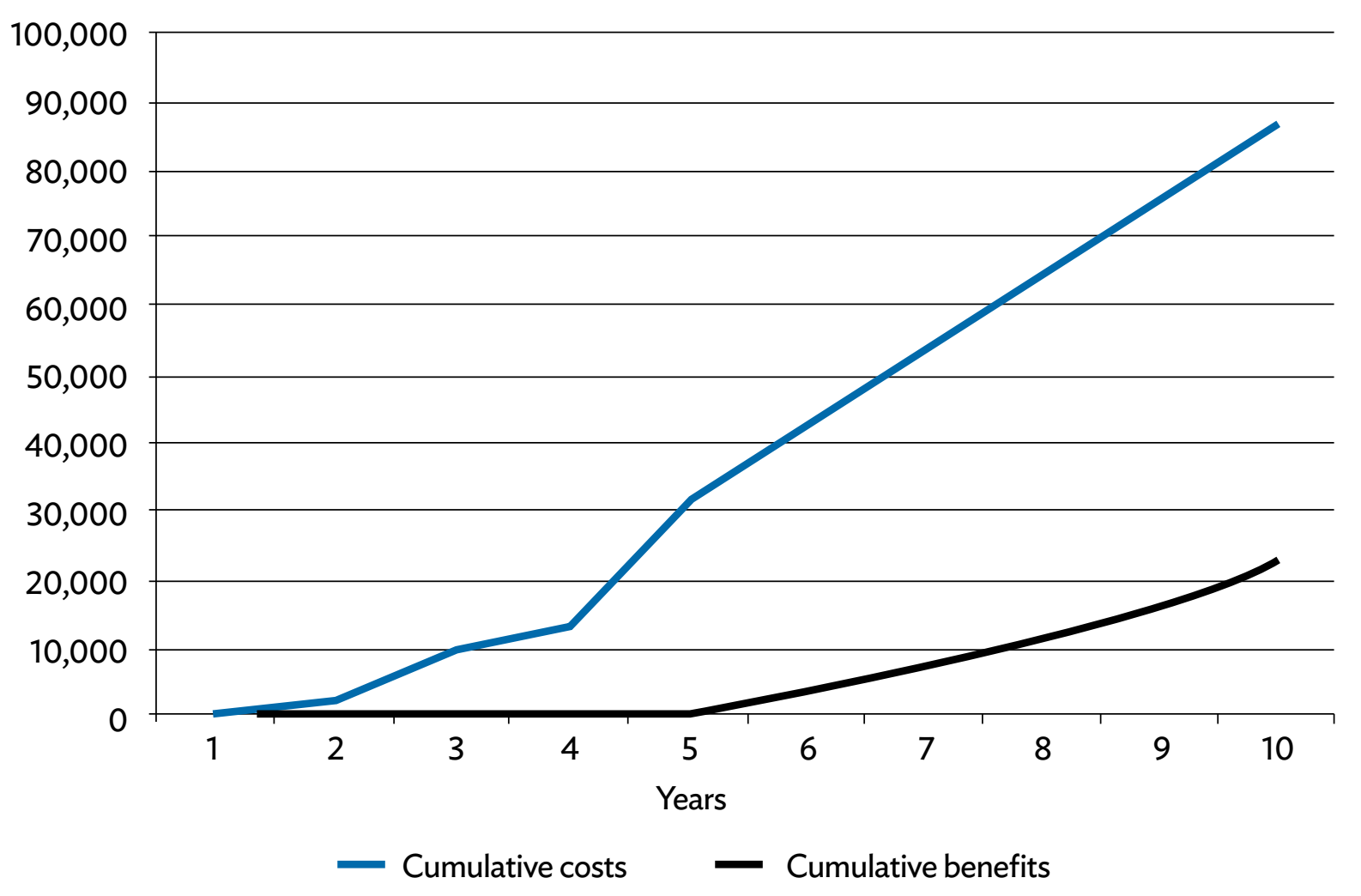

Source: Authors.

For redeployed resources, health organizations' budgets and annual accounts provide some of the information needed for employees. Costing methodologies should cover shares of existing computer and network capacities. For EHRs, redeployable resources can be a large aggregation of many small opportunities, and successful redeployment can be challenging. DHIF can identify this before implementation, so decision-makers can ensure that their change management resources are in place promptly.

All costs and benefits in prospective appraisals rely on effective and realistic assumptions and estimates. It is essential that decision-makers and stakeholders review these rigorously and frequently. DHIF enables these changes to be implemented quickly and sent for further review, as part of digital health's engagement strategy. 


\section{APPENDIX 3: TOOLKITS}

\begin{tabular}{|c|c|c|}
\hline Author & Name & Link \\
\hline AeHIN & National eHealth Capacity Roadmap & $\begin{array}{l}\text { http://www.aehin.org/Resources/eHealth. } \\
\text { aspx }\end{array}$ \\
\hline COBIT 5 & $\begin{array}{l}\text { Framework for the Governance and Man- } \\
\text { agement of Enterprise IT }\end{array}$ & $\begin{array}{l}\text { http://www.isaca.org/COBIT/Pages/de- } \\
\text { fault.aspx }\end{array}$ \\
\hline ECRI & $\begin{array}{l}\text { Patient Identification Toolkit (not focus- } \\
\text { ing on developing countries) }\end{array}$ & $\begin{array}{l}\text { https://www.ecri.org/Resources/HIT/ } \\
\text { Patient\%2olD/Patient_Identification_- } \\
\text { Toolkit_final.pdf }\end{array}$ \\
\hline Health Enabled & Digital Health RMNCH Toolkit & $\begin{array}{l}\text { http://www.lifesavingcommodities.org/ } \\
\text { wp-content/uploads/2015/11/ } \\
\text { digital_health_rmnch.pdf }\end{array}$ \\
\hline HIGAF & $\begin{array}{l}\text { Health Information Governance and } \\
\text { Architecture Framework }\end{array}$ & Asian Development Bank \\
\hline iHRIS & $\begin{array}{l}\text { National Health Information System As- } \\
\text { sessment Tool (developed by the Health } \\
\text { Metrics Network) }\end{array}$ & $\begin{array}{l}\text { https://www.ihris.org/toolkit-new/assess/ } \\
\text { worksheet-his-assessment-survey/ }\end{array}$ \\
\hline Joint Learning Network & $\begin{array}{l}\text { Using Data Analytics to Monitor Health } \\
\text { Provider Payment Systems: A Toolkit } \\
\text { for Countries Working Toward Universal } \\
\text { Health Coverage }\end{array}$ & $\begin{array}{l}\text { http://www.path.org/publications/files/ } \\
\text { DHS_jln_full_toolkit.pdf }\end{array}$ \\
\hline K4Health & $\begin{array}{l}\text { A compendium of how-to guides on } \\
\text { concept development, human-centered } \\
\text { design, strategy, situation analysis, data } \\
\text { collection, working with stakeholders, and } \\
\text { cost models }\end{array}$ & $\begin{array}{l}\text { http://www.mhealthknowledge.org/ } \\
\text { resource-type/tools-guides }\end{array}$ \\
\hline $\begin{array}{l}\text { Organisation for Economic } \\
\text { Co-operation and Development }\end{array}$ & Digital Government Toolkit & $\begin{array}{l}\text { http://www.oecd.org/governance/digital- } \\
\text { government/toolkit/ }\end{array}$ \\
\hline Optima & $\begin{array}{l}\text { A tool for public health investments } \\
\text { (HIV, TB, Nutrition, HCV, Child Health) }\end{array}$ & http://optimamodel.com/ \\
\hline UN Foundation & $\begin{array}{l}\text { Assessing the Enabling Environment for } \\
\text { Establishing a Contextualized National } \\
\text { Digital Health Strategy }\end{array}$ & $\begin{array}{l}\text { http://www.mhealthknowledge.org/sites/ } \\
\text { default/files/Toolkit-assessing-enabling- } \\
\text { environment_FINAL.pdf }\end{array}$ \\
\hline UNICEF & $\begin{array}{l}\text { A Process Guide and Toolkit for Strength- } \\
\text { ening Public Health Supply Chains } \\
\text { through Capacity Development }\end{array}$ & $\begin{array}{l}\text { https://www.google.com/url?sa=t\&rct=j\& } \\
\text { q=\&esrc=s\&source=web\&cd=4\&ved=oa } \\
\text { hUKEwjb4ampscLWAhXIj5QKHacYAvs } \\
\text { QFgg3MAM\&url=https\%3A\%2F\%2Fpeop } \\
\text { lethatdeliver.org\%2Fptd\%2Fdownload\%2 } \\
\text { Ffile\%2Ffid\%2F691\&usg=AFQjCNHiUD- } \\
\text { 9qaSuDGyJbxFoQKkUX_OUIQ }\end{array}$ \\
\hline UNICEF & EQUIST: Equitable Impact Sensitive Tool & $\begin{array}{l}\text { http://equist.info/files/general_files/ } \\
\text { User_Guide.pdf }\end{array}$ \\
\hline USAID/DIAL & $\begin{array}{l}\text { Closing the Access Gap: Innovation to } \\
\text { Accelerate Universal Internet Adoption }\end{array}$ & $\begin{array}{l}\text { https://www.usaid.gov/sites/default/files/ } \\
\text { documents/15396/Closing-the-Access- } \\
\text { Gap.pdf }\end{array}$ \\
\hline World Bank & Digital Identity Toolkit (Africa) & $\begin{array}{l}\text { http://documents.worldbank.org/curated/ } \\
\text { en/147961468203357928/Digital-identity- } \\
\text { toolkit-a-guide-for-stakeholders-in- } \\
\text { Africa }\end{array}$ \\
\hline
\end{tabular}


Appendix 3 Table: continued

\begin{tabular}{lll}
\hline Author & \multicolumn{1}{c}{ Name } & \multicolumn{1}{c}{ Link } \\
\hline WHO & $\begin{array}{l}\text { Monitoring and evaluating digital health } \\
\text { interventions } \\
\text { A practical guide to conducting research } \\
\text { and assessment }\end{array}$ & $\begin{array}{l}\text { http://www.who.int/reproductivehealth/ } \\
\text { publications/mhealth/digital-health- } \\
\text { interventions/en/ }\end{array}$ \\
\hline WHO & $\begin{array}{l}\text { Civil Registration and Vital Statistics } \\
\text { Rapid Assessment Toolkit }\end{array}$ & $\begin{array}{l}\text { http://apps.who.int/iris/bit- } \\
\text { stream/10665/70470/1/WHO_IER_HSI__ } \\
\text { STM_2010.1_eng.pdf }\end{array}$ \\
\hline WHO & National eHealth Strategy Toolkit & $\begin{array}{l}\text { http://www.who.int/ehealth/publications/ } \\
\text { overview.pdf?ua=1 }\end{array}$ \\
\hline
\end{tabular}

AeHIN = Asia eHealth Information Network, ECRI = ECRI Institute Patient Safety Organization, iHRIS =integrated Human Resources Information Solution, OECD = Organisation for Economic Co-operation and Development, USAID/DIAL = United States Agency for International Development/Digital Impact Alliance, $\mathrm{WHO}=$ World Health Organization.

Source: Authors. 


\section{APPENDIX 4: POTENTIAL AREAS FOR SAVING COSTS AND INCREASING BENEFITS}

This appendix is not intended to be comprehensive, but gives an indication as to how a sequence of investments, over time, can provide what is needed to deliver patient-centered and connected care through digital health. It addresses the opportunities for the following groups of stakeholders:

(i) public, patients, and carers;

(ii) health workers;

(iii) health care managers; and

(iv) health care organizations.

Many opportunities, technical issues, and infrastructure overlap among these four groups. This shows how components of digital investment can lead to equivalent benefits across several stakeholders, although the impacts are different. For example, saving lives is clear benefit not only for patients and carers but also for health workers, who may consider it a personal achievement and for health care organizations (achieving a strategic goal).

\begin{tabular}{|c|c|c|c|}
\hline Opportunities & $\begin{array}{l}\text { Opportunities for } \\
\text { Saving Costs and } \\
\text { Increasing Benefits }\end{array}$ & $\begin{array}{l}\text { Technical Solutions and } \\
\text { Investments Required }\end{array}$ & $\begin{array}{l}\text { Basic Infrastructure and } \\
\text { Registries (in addition to } \\
\text { electricity and networks) }\end{array}$ \\
\hline \multicolumn{4}{|c|}{ A. The Public, Patients, and Carers } \\
\hline Public information & $\begin{array}{l}\text { - Potential to save some lives } \\
\text { - } \text { Potential to avoid some } \\
\text { - More targeted distribution } \\
\text { of information reaching } \\
\text { people in need } \\
\text { - Reduced personal costs for } \\
\text { curative treatment } \\
\text { - Lower sickness rate may } \\
\text { lead to greater productivity } \\
\text { - Better lifestyle choices and } \\
\text { health behaviors }\end{array}$ & $\begin{array}{l}\text { - Government health infor- } \\
\text { mation system } \\
\text { - Knowledge support tools, } \\
\text { e.g., audio/video clips re- } \\
\text { garding healthy behaviors } \\
\text { - Websites and portals } \\
\text { - Awareness-raising apps } \\
\text { - Social media tools; } \\
\text { - Short message service } \\
\text { (SMS) reminders }\end{array}$ & $\begin{array}{l}\text { - Standards for knowl- } \\
\text { edge content } \\
\text { - Governance policy for } \\
\text { use of Social media }\end{array}$ \\
\hline $24 / 7$ call centers & $\begin{array}{l}\text { Decreased need for in- } \\
\text { person clinic visits } \\
\text { Reduced travel spending } \\
\text { and time }\end{array}$ & - Call center applications & $\begin{array}{l}\text { - Agreed protocols for } \\
\text { call handlers }\end{array}$ \\
\hline $\begin{array}{l}\text { Better-informed patients } \\
\text { and carers }\end{array}$ & $\begin{array}{l}\text { - Compliance with treatment } \\
\text { regimes } \\
\text { - Better lifestyle choices } \\
\text { behaviors }\end{array}$ & $\begin{array}{l}\text { - Healthcare knowledge } \\
\text { support content and apps } \\
\text { - Home-based monitoring; } \\
\text { wearables }\end{array}$ & $\begin{array}{l}\text { Mobile devices that } \\
\text { have off or online } \\
\text { access to knowledge } \\
\text { support }\end{array}$ \\
\hline Safer health care & $\begin{array}{l}\text { - } \text { - Rewer errors } \\
\text { - } \text { with affected patients } \\
\text { - Shorter hospital stays }\end{array}$ & $\begin{array}{l}\text { Health worker has point } \\
\text { of care (POC) knowledge } \\
\text { support } \\
\text { Clinical decision sup- } \\
\text { port (requires electronic } \\
\text { records [EPRs], which } \\
\text { contain data that can be } \\
\text { interpreted by the algo- } \\
\text { rithms that generate the } \\
\text { advice/alerts needed) }\end{array}$ & $\begin{array}{l}\text { Mobile devices that } \\
\text { have off or online ac- } \\
\text { cess to knowledge sup- } \\
\text { port, or clinical decision } \\
\text { support }\end{array}$ \\
\hline
\end{tabular}


Appendix 4 Table: continued

\begin{tabular}{|c|c|c|c|}
\hline Opportunities & $\begin{array}{l}\text { Opportunities for } \\
\text { Saving Costs and } \\
\text { Increasing Benefits }\end{array}$ & $\begin{array}{l}\text { Technical Solutions and } \\
\text { Investments Required }\end{array}$ & $\begin{array}{l}\text { Basic Infrastructure and } \\
\text { Registries (in addition to } \\
\text { electricity and networks) }\end{array}$ \\
\hline Disease surveillance & $\begin{array}{l}\text { Enables real-time surveil- } \\
\text { lance, resource allocation } \\
\text { that has the potential to } \\
\text { save some lives, and avoids } \\
\text { some illnesses and infec- } \\
\text { tions } \\
\text { - Better response leading to } \\
\text { fewer deaths and morbidity } \\
\text { - Ensures patients use the } \\
\text { most appropriate available } \\
\text { health care facilities }\end{array}$ & $\begin{array}{l}\text { - Notifiable disease surveil- } \\
\text { lance systems } \\
\text { - Mobile devices with } \\
\text { health survey and disease } \\
\text { surveillance apps }\end{array}$ & $\begin{array}{l}\text { - Standards for reporting } \\
\text { (notifiable) diseases } \\
\text { - Geo-coding standards } \\
\text { - Demographic census } \\
\text { data (supplemented by } \\
\text { population registries) }\end{array}$ \\
\hline Patient registration & $\begin{array}{l}\text { - One-time registration } \\
\text { - Information available on } \\
\text { subsequent visits } \\
\text { - Shorter waiting times in } \\
\text { health care facilities } \\
\text { - Serves multiple purposes } \\
\text { (e.g., vital statistics regis- } \\
\text { tries in addition to care) }\end{array}$ & $\begin{array}{l}\text { - Electronic patient regis- } \\
\text { tration system } \\
\text { - Hospital management } \\
\text { system } \\
\text { - Interface for civil registra- } \\
\text { tion and vital statistics } \\
\text { reporting }\end{array}$ & $\begin{array}{l}\text { - Standards for patient } \\
\text { identity (ID). } \\
\text { - Master patient index/ } \\
\text { health client registry/ } \\
\text { unique patient ID }\end{array}$ \\
\hline Online appointments & $\begin{array}{l}\text { - Improved access and ef- } \\
\text { ficiency } \\
\text { - Shorter waiting times } \\
\text { - More patients seen }\end{array}$ & $\begin{array}{l}\text { - Electronic patient regis- } \\
\text { tration system } \\
\text { - Hospital management } \\
\text { system }\end{array}$ & $\begin{array}{l}\text { Agreed and shared } \\
\text { standards for booking } \\
\text { appointments between } \\
\text { hospitals and primary } \\
\text { care }\end{array}$ \\
\hline Referrals & $\begin{array}{l}\text { Efficient access to clos- } \\
\text { est, appropriate available } \\
\text { resources } \\
\text { - Coordinated and integrated } \\
\text { healthcare leading to better } \\
\text { health outcomes }\end{array}$ & $\begin{array}{l}\text { - Electronic patient regis- } \\
\text { tration system } \\
\text { - Hospital management } \\
\text { system } \\
\text { - Simple knowledge support } \\
\text { for community-based } \\
\text { health workers } \\
\text { - Clinical decision support } \\
\text { where there are electronic } \\
\text { medical records } \\
\text { - mHealth application/SMS }\end{array}$ & $\begin{array}{l}\text { - } \text { Agreed standards for } \\
\text { referrals } \\
\text { - } \text { Master patient index/ } \\
\text { health client registry/ } \\
\text { unique patient ID } \\
\text { - Health facility registry } \\
\text { - Health worker registry } \\
\text { - Geo-enabling technol- } \\
\text { ogy (e.g., for district } \\
\text { codes, village codes) }\end{array}$ \\
\hline $\begin{array}{l}\text { Creation of persistent } \\
\text { record }\end{array}$ & $\begin{array}{l}\text { - Improved speed and ef- } \\
\text { ficiency of care delivered } \\
\text { - Information-based devel- } \\
\text { oped for wide variety of } \\
\text { direct care and administra- } \\
\text { tive uses } \\
\text { - Data is entered once }\end{array}$ & $\begin{array}{l}\text { - Electronic patient regis- } \\
\text { tration system } \\
\text { - Hospital management } \\
\text { system } \\
\text { - EPRs systems with data } \\
\text { entry (ideally at POC) }\end{array}$ & $\begin{array}{l}\text { - } \text { Clinical data standards } \\
\text { haster patient index/ } \\
\text { health client registry/ } \\
\text { unique patient ID }\end{array}$ \\
\hline Scheduling follow-ups & $\begin{array}{l}\text { - Automatic messaging to } \\
\text { patients and providers }\end{array}$ & $\begin{array}{l}\text { - Electronic patient regis- } \\
\text { tration system } \\
\text { - EPRs } \\
\text { - Hospital management } \\
\text { system electronic referral } \\
\text { system } \\
\text { - mHealth application/short } \\
\text { message service reminders }\end{array}$ & $\begin{array}{l}\text { - } \text { Clinical data standards } \\
\text { haster patient index/ } \\
\text { health client registry/ } \\
\text { unique patient ID }\end{array}$ \\
\hline
\end{tabular}


Appendix 4 Table: continued

\begin{tabular}{|c|c|c|c|}
\hline Opportunities & $\begin{array}{l}\text { Opportunities for } \\
\text { Saving Costs and } \\
\text { Increasing Benefits }\end{array}$ & $\begin{array}{l}\text { Technical Solutions and } \\
\text { Investments Required }\end{array}$ & $\begin{array}{l}\text { Basic Infrastructure and } \\
\text { Registries (in addition to } \\
\text { electricity and networks) }\end{array}$ \\
\hline $\begin{array}{l}\text { Faster and safer diagnos- } \\
\text { tics }\end{array}$ & $\begin{array}{l}\text { - Faster and better-informed } \\
\text { diagnoses } \\
\text { - Reduce medication errors } \\
\text { (e.g., transcription) and } \\
\text { better cost control of drugs } \\
\text { - Shorter waiting times for } \\
\text { results and prescriptions }\end{array}$ & $\begin{array}{l}\text { - Computerized physician } \\
\text { order entry system } \\
\text { - Integration with clini- } \\
\text { cal decision support and } \\
\text { EPRs } \\
\text { - Picture archiving and } \\
\text { communication system } \\
\text { - Radiology information } \\
\text { - } \text { system }\end{array}$ & $\begin{array}{l}\text { - } \text { Master patient index } \\
\text { - } \quad \text { Clinical terminologies }\end{array}$ \\
\hline Remote diagnostics & $\begin{array}{l}\text { - Reduced clinic visits } \\
\text { - Saves travel costs and time } \\
\text { for patients and carers } \\
\text { - Improved patient triage } \\
\text { - More efficient use of time } \\
\text { of skilled health workers }\end{array}$ & $\begin{array}{l}\text { - Telehealth } \\
\text { - Electronic patient regis- } \\
\text { tration system } \\
\text { - Diagnostic ordering and } \\
\text { reporting systems func- } \\
\text { tions } \\
\text { - Hospital management } \\
\text { - } \text { system } \\
\text { ingmote patient monitor- } \\
\text { ing application + software }\end{array}$ & $\begin{array}{l}\text { - Standards } \\
\text { - Master patient index/ } \\
\text { health client registry/ } \\
\text { unique patient ID }\end{array}$ \\
\hline $\begin{array}{l}\text { Better integrated health- } \\
\text { care across multidiscipli- } \\
\text { nary teams }\end{array}$ & $\begin{array}{l}\text { - Shorter waiting times } \\
\text { - Shared clinical data across } \\
\text { providers } \\
\text { - Liberated capacity enables } \\
\text { increased access to com- } \\
\text { munities previously unable } \\
\text { to access health care } \\
\text { - Availability of modern } \\
\text { health care }\end{array}$ & $\begin{array}{l}\text { - Health information ex- } \\
\text { changes } \\
\text { - Electronic health records } \\
\text { (EHRs) as summaries } \\
\text { - EHRs as full records. To } \\
\text { deliver full EHRs at a } \\
\text { national or regional level } \\
\text { assumes the management } \\
\text { infrastructure to support } \\
\text { EPRs (within) all relevant } \\
\text { organizations is in place }\end{array}$ & $\begin{array}{l}\text { EHRs require popu- } \\
\text { lation registers that } \\
\text { enable unique identi- } \\
\text { fication of individuals } \\
\text { and their records (much } \\
\text { of which may be sum- } \\
\text { marized). }\end{array}$ \\
\hline
\end{tabular}

\section{B. Opportunities for Health Workers}

Public information - More targeted distribution of information

- Reduced time needed for curative treatment
- Government health information system

- Knowledge support tools, e.g., audio/video clips regarding healthy behaviors

- Websites and portals

- Awareness-raising apps

- Social media tools

- SMS reminders

\begin{tabular}{|c|c|c|c|}
\hline $24 / 7$ call centers & $\begin{array}{l}\text { Decreased need for in- } \\
\text { person clinic visits and } \\
\text { health workers time }\end{array}$ & - Call center applications & - Call center applications \\
\hline Better-informed patients & $\begin{array}{l}\text { Compliance with treatment } \\
\text { regimes, with less demand } \\
\text { on health workers time } \\
\text { - Better lifestyle behaviors, } \\
\text { with less demand for health } \\
\text { workers time } \\
\text { - Potential to save some lives } \\
\text { and avoid some infections }\end{array}$ & $\begin{array}{l}\text { - Health care knowledge } \\
\text { support content and apps } \\
\text { - Home-based monitoring; } \\
\text { wearables }\end{array}$ & $\begin{array}{l}\text { Mobile devices that } \\
\text { have off-line or online } \\
\text { access to knowledge } \\
\text { support }\end{array}$ \\
\hline
\end{tabular}

- Standards for knowledge content

- Governance policy for use of social media 
Appendix 4 Table: continued

\begin{tabular}{|c|c|c|c|}
\hline Opportunities & $\begin{array}{l}\text { Opportunities for } \\
\text { Saving Costs and } \\
\text { Increasing Benefits }\end{array}$ & $\begin{array}{l}\text { Technical Solutions and } \\
\text { Investments Required }\end{array}$ & $\begin{array}{l}\text { Basic Infrastructure and } \\
\text { Registries (in addition to } \\
\text { electricity and networks) }\end{array}$ \\
\hline Safer health care & $\begin{array}{l}\text { - Fewer errors which protect } \\
\text { health workers } \\
\text { - Reduced liability costs }\end{array}$ & $\begin{array}{l}\text { - Health worker has POC } \\
\text { knowledge support } \\
\text { - Clinical decision support } \\
\text { (requires EPRs which } \\
\text { contain data that can be } \\
\text { interpreted by the algo- } \\
\text { rithms that generate the } \\
\text { advice/alerts needed) }\end{array}$ & $\begin{array}{l}\text { Mobile devices that } \\
\text { have off-line or online } \\
\text { access to knowledge } \\
\text { support, or clinical deci- } \\
\text { sion support }\end{array}$ \\
\hline $\begin{array}{l}\text { Supply chain manage- } \\
\text { ment }\end{array}$ & $\begin{array}{l}\text { - Avoid staff frustration and } \\
\text { - } \text { dissatisfaction } \\
\text { - Avoid stock-outs } \\
\text { levels } \\
\text { - Faster recovery from } \\
\text { supply-side disruption } \\
\text { - Fraud protection (e.g., fake } \\
\text { medicines) }\end{array}$ & $\begin{array}{l}\text { - Stock management } \\
\text { system } \\
\text { - For availability need sup- } \\
\text { ply chain management } \\
\text { system (including cold } \\
\text { chain management of } \\
\text { drugs) } \\
\text { - Bar-coded drugs (and } \\
\text { readers) } \\
\text { - Bar-coded medical and } \\
\text { surgical supplies (and } \\
\text { readers) }\end{array}$ & $\begin{array}{l}\text { - } \text { Medicine registry } \\
\text { - } \text { Drug registry } \\
\text { - } \text { supdical and surgical } \\
\text { - Drug and devices codes } \\
\text { and standards, with ap- } \\
\text { propriate bar codes }\end{array}$ \\
\hline Disease surveillance & $\begin{array}{l}\text { Enables real-time surveil- } \\
\text { lance, resource allocation } \\
\text { resulting in better use of } \\
\text { health workers time } \\
\text { - Potential to save some lives } \\
\text { and avoid some illnesses } \\
\text { and infections }\end{array}$ & $\begin{array}{l}\text { - Notifiable disease surveil- } \\
\text { lance systems. } \\
\text { - Mobile devices with } \\
\text { health survey and disease } \\
\text { surveillance apps }\end{array}$ & $\begin{array}{l}\text { - Standards for reporting } \\
\text { (notifiable) diseases. } \\
\text { - Geo-coding standards } \\
\text { - Demographic census } \\
\text { data (supplemented by } \\
\text { population registries) }\end{array}$ \\
\hline Patient registration & $\begin{array}{l}\text { - One-time registration } \\
\text { - Information available on } \\
\text { subsequent visits } \\
\text { - Serves multiple purposes } \\
\text { (e.g., vital statistics regis- } \\
\text { tries in addition to care) } \\
\text { - Saves health workers' time }\end{array}$ & $\begin{array}{l}\text { - Electronic patient regis- } \\
\text { tration system } \\
\text { - Hospital management } \\
\text { system } \\
\text { - Interface for civil registra- } \\
\text { tion and vital statistics } \\
\text { reporting }\end{array}$ & $\begin{array}{l}\text { - Standards for patient ID } \\
\text { - Master patient index/ } \\
\text { health client registry/ } \\
\text { unique patient ID } \\
\text { - Information governance } \\
\text { standards }\end{array}$ \\
\hline Online appointments & $\begin{array}{l}\text { - Improved access and ef- } \\
\text { ficiency } \\
\text { - More patients seen }\end{array}$ & $\begin{array}{l}\text { - Electronic patient regis- } \\
\text { tration system } \\
\text { - Hospital management } \\
\text { system }\end{array}$ & $\begin{array}{l}\text { Agreed and shared } \\
\text { standards for booking } \\
\text { appointments between } \\
\text { hospitals and primary } \\
\text { care }\end{array}$ \\
\hline Referrals & $\begin{array}{l}\text { Efficient access to clos- } \\
\text { est, appropriate available } \\
\text { resources } \\
\text { - Coordinated care }\end{array}$ & $\begin{array}{l}\text { - Electronic patient regis- } \\
\text { tration system } \\
\text { - Hospital management } \\
\text { system } \\
\text { - Simple knowledge support } \\
\text { for community-based } \\
\text { health workers } \\
\text { - Clinical decision support } \\
\text { where there are electronic } \\
\text { medical records } \\
\text { - mHealth application/SMS }\end{array}$ & $\begin{array}{l}\text { - } \text { Agreed standards for } \\
\text { referrals } \\
\text { - Master patient index/ } \\
\text { health client registry/ } \\
\text { unique patient ID } \\
\text { - Health facility registry } \\
\text { - Health worker registry } \\
\text { - } \text { Geo-enabling technol- } \\
\text { ogy, including district } \\
\text { and village codes }\end{array}$ \\
\hline
\end{tabular}


Appendix 4 Table: continued

\begin{tabular}{|c|c|c|c|}
\hline Opportunities & $\begin{array}{l}\text { Opportunities for } \\
\text { Saving Costs and } \\
\text { Increasing Benefits }\end{array}$ & $\begin{array}{l}\text { Technical Solutions and } \\
\text { Investments Required }\end{array}$ & $\begin{array}{l}\text { Basic Infrastructure and } \\
\text { Registries (in addition to } \\
\text { electricity and networks) }\end{array}$ \\
\hline $\begin{array}{l}\text { Creation of persistent } \\
\text { record }\end{array}$ & $\begin{array}{l}\text { - Improved speed and ef- } \\
\text { ficiency of care delivered } \\
\text { - Information-based devel- } \\
\text { oped for a wide variety of } \\
\text { direct care and administra- } \\
\text { tive uses } \\
\text { - Data is entered once, sav- } \\
\text { ing health worker time }\end{array}$ & $\begin{array}{l}\text { - Electronic patient regis- } \\
\text { tration system } \\
\text { - Hospital management } \\
\text { system } \\
\text { - EPRs systems with data } \\
\text { entry (ideally at POC) }\end{array}$ & $\begin{array}{l}\text { - } \text { Clinical data standards } \\
\text { haster patient index/ } \\
\text { health client registry/ } \\
\text { unique patient ID }\end{array}$ \\
\hline Scheduling follow-ups & $\begin{array}{l}\text { Automatic messaging to } \\
\text { public and providers saves } \\
\text { health worker time }\end{array}$ & $\begin{array}{l}\text { - } \text { EPR system } \\
\text { - EPRs } \\
\text { - Hospital management } \\
\text { system electronic referral } \\
\text { system } \\
\text { mHealth application/SMS } \\
\text { reminders }\end{array}$ & $\begin{array}{l}\text { - Clinical data standards } \\
\text { - Master patient index/ } \\
\text { health client registry/ } \\
\text { unique patient ID }\end{array}$ \\
\hline $\begin{array}{l}\text { Faster and safer diagnos- } \\
\text { tics }\end{array}$ & $\begin{array}{l}\text { - Faster and better-informed } \\
\text { diagnoses } \\
\text { - Medication errors (e.g., } \\
\text { transcription) reduced and } \\
\text { better cost control of drugs } \\
\text { - Shorter waiting times for } \\
\text { results and prescriptions }\end{array}$ & $\begin{array}{l}\text { - Computerized physician } \\
\text { - Inder entry system } \\
\text { cal decision support and } \\
\text { EPRs } \\
\text { - Picture archiving and } \\
\text { communication system } \\
\text { - Radiology information } \\
\text { - } \text { Pystem }\end{array}$ & $\begin{array}{l}\text { - } \text { Master patient index } \\
\text { - } \text { Drug dictionary } \\
\text { - Informal terminologies } \\
\text { standards }\end{array}$ \\
\hline Remote diagnostics & $\begin{array}{l}\text { - Fewer clinic visits } \\
\text { - Saves time for patients and } \\
\text { health workers } \\
\text { - Improved patient triage } \\
\text { - More efficient use of time } \\
\text { of skilled health workers }\end{array}$ & $\begin{array}{l}\text { - Telehealth } \\
\text { - Electronic patient regis- } \\
\text { tration system } \\
\text { - EPRs } \\
\text { - Diagnostic ordering and } \\
\text { reporting systems func- } \\
\text { tions } \\
\text { - Hospital management } \\
\text { system } \\
\text { - Remote patient monitor- } \\
\text { ing application + software }\end{array}$ & $\begin{array}{l}\text { - Clinical data standards } \\
\text { - Master patient index/ } \\
\text { health client registry/ } \\
\text { unique patient ID } \\
\text { - Information governance } \\
\text { standards }\end{array}$ \\
\hline $\begin{array}{l}\text { Better information } \\
\text { sharing and integrated } \\
\text { health care across multi- } \\
\text { disciplinary teams }\end{array}$ & $\begin{array}{l}\text { Faster access to shared } \\
\text { clinical data across provid- } \\
\text { ers } \\
\text { - Improved team working }\end{array}$ & $\begin{array}{l}\text { - Health information ex- } \\
\text { changes } \\
\text { - EHRs as summaries } \\
\text { - EHRs as full records. To } \\
\text { deliver full EHRs at a } \\
\text { national or regional level } \\
\text { assumes the management } \\
\text { infrastructure to support } \\
\text { EPRs (within) all relevant } \\
\text { organizations is in place }\end{array}$ & $\begin{array}{l}\text { EHRs require popu- } \\
\text { lation registers that } \\
\text { enable unique identi- } \\
\text { fication of individuals } \\
\text { and their records (much } \\
\text { of which may be sum- } \\
\text { marized) } \\
\text { - Information governance } \\
\text { standards }\end{array}$ \\
\hline $\begin{array}{l}\text { Continuing professional } \\
\text { development (CPD) } \\
\text { accreditation }\end{array}$ & $\begin{array}{l}\text { Clinical staff can access } \\
\text { their clinical activities for } \\
\text { professional accreditation } \\
\text { and continuing professional } \\
\text { development }\end{array}$ & - $\mathrm{EHRs}$ & $\begin{array}{l}\text { - Human resources } \\
\text { standards } \\
\text { - Information governance } \\
\text { standards }\end{array}$ \\
\hline
\end{tabular}


Appendix 4 Table: continued

\begin{tabular}{|c|c|c|c|}
\hline Opportunities & $\begin{array}{l}\text { Opportunities for } \\
\text { Saving Costs and } \\
\text { Increasing Benefits }\end{array}$ & $\begin{array}{l}\text { Technical Solutions and } \\
\text { Investments Required }\end{array}$ & $\begin{array}{l}\text { Basic Infrastructure and } \\
\text { Registries (in addition to } \\
\text { electricity and networks) }\end{array}$ \\
\hline Clinical Audit & $\begin{array}{l}\text { - Prompt access to clinical } \\
\text { data for clinical audit sup- } \\
\text { porting increased profes- } \\
\text { sionalism } \\
\text { - Continuous improvement } \\
\text { of quality of care } \\
\text { - Faster identification of } \\
\text { areas to improve }\end{array}$ & $\begin{array}{l}\text { - } \text { EHRs } \\
\text { - Enquiry software }\end{array}$ & $\begin{array}{l}\text { - Clinical data standards } \\
\text { - Information governance } \\
\text { standards } \\
\text { - Data warehouses }\end{array}$ \\
\hline \multicolumn{4}{|c|}{ C. Opportunities for Health Care Managers } \\
\hline $\begin{array}{l}\text { Understanding the health } \\
\text { needs and demands of } \\
\text { populations }\end{array}$ & $\begin{array}{l}\text { - Real time updates on ser- } \\
\text { vices provided to defined } \\
\text { populations } \\
\text { - Electronic health surveys } \\
\text { and faster access to infor- } \\
\text { mation } \\
\text { - Spatial analyses } \\
\text { - Early warning of health } \\
\text { security threats }\end{array}$ & $\begin{array}{l}\text { Mobile data collection } \\
\text { (devices and training) } \\
\text { Tools for data analysis } \\
\text { and acquiring data from } \\
\text { providers (e.g. for govern- } \\
\text { ment agencies, nongov- } \\
\text { ernment organizations) }\end{array}$ & $\begin{array}{l}\text { - Geo-coding standards } \\
\text { - Information governance } \\
\text { standards }\end{array}$ \\
\hline Staff management & $\begin{array}{l}\text { - Ability to support, commu- } \\
\text { nicate with, and supervise } \\
\text { staff in real time } \\
\text { - Improved management of } \\
\text { staff resources, given ability } \\
\text { to mine activity data to } \\
\text { monitor staff performance } \\
\text { through various filters, } \\
\text { including at the individual } \\
\text { or aggregate level }\end{array}$ & $\begin{array}{l}\text { - Human resources man- } \\
\text { agement system } \\
\text { Resource mapping soft- } \\
\text { ware (facilities and health } \\
\text { workers, ideally linked to } \\
\text { Global Positioning System } \\
\text { data) }\end{array}$ & $\begin{array}{l}\text { - Standards for human } \\
\text { resources and perfor- } \\
\text { mance assessment } \\
\text { - Health worker registry } \\
\text { - Health facility registry }\end{array}$ \\
\hline Staff training & $\begin{array}{l}\text { Lower training costs with } \\
\text { online courses accessed } \\
\text { remotely and delivered at } \\
\text { scale } \\
\text { - Improve effectiveness with } \\
\text { virtual peer-to-peer learn- } \\
\text { ing enabled } \\
\text { - Rapid deployment of online } \\
\text { learning }\end{array}$ & $\begin{array}{l}\text { - Commissioned blended } \\
\text { and online learning } \\
\text { courses } \\
\text { - Commissioned content } \\
\text { (audiovisual) for use on } \\
\text { personal mobile devices } \\
\text { - Human resources system } \\
\text { with learning registers to } \\
\text { track learner engagement } \\
\text { - Apps to support improve- } \\
\text { ments in learning behav- } \\
\text { iors }\end{array}$ & $\begin{array}{l}\text { - Standards for human } \\
\text { resources and CPD } \\
\text { Bring your own device } \\
\text { (BYOD) policy } \\
\text { - Health worker registry } \\
\text { - Health facility registry }\end{array}$ \\
\hline $\begin{array}{l}\text { Supply chain manage- } \\
\text { ment }\end{array}$ & $\begin{array}{l}\text { - Avoid stock-outs } \\
\text { - Avoid excessive stock } \\
\text { levels } \\
\text { - Faster recovery from } \\
\text { supply-side disruption } \\
\text { - Fraud protection (e.g., fake } \\
\text { medicines) }\end{array}$ & $\begin{array}{l}\text { - Stock management } \\
\text { system } \\
\text { - For availability need sup- } \\
\text { ply chain management } \\
\text { system (including cold } \\
\text { chain management of } \\
\text { drugs) } \\
\text { - Bar-coded drugs (and } \\
\text { readers) } \\
\text { Bar-coded medical and } \\
\text { surgical supplies (and } \\
\text { readers) }\end{array}$ & $\begin{array}{l}\text { - } \text { Medicine registry } \\
\text { - } \text { Drug registry } \\
\text { - } \text { Medical and surgical } \\
\text { - } \text { Drug and des registries } \\
\text { and standards, with ap- } \\
\text { propriate bar codes }\end{array}$ \\
\hline
\end{tabular}


Appendix 4 Table: continued

\begin{tabular}{|c|c|c|c|}
\hline Opportunities & $\begin{array}{l}\text { Opportunities for } \\
\text { Saving Costs and } \\
\text { Increasing Benefits }\end{array}$ & $\begin{array}{l}\text { Technical Solutions and } \\
\text { Investments Required }\end{array}$ & $\begin{array}{l}\text { Basic Infrastructure and } \\
\text { Registries (in addition to } \\
\text { electricity and networks) }\end{array}$ \\
\hline Clinical audits & $\begin{array}{l}\text { - Continuous improvement } \\
\text { of quality of care } \\
\text { - Faster identification of } \\
\text { areas to improve }\end{array}$ & $\begin{array}{l}\text { - EPRs } \\
\text { - Disease-specific analytics }\end{array}$ & $\begin{array}{l}\text { - Agreed (performance } \\
\text { and) data standards } \\
\text { - Data warehouses }\end{array}$ \\
\hline Performance review & $\begin{array}{l}\text { Easier and more timely ag- } \\
\text { gregation of data by factors, } \\
\text { including district, region, } \\
\text { provider, and disease } \\
\text { - Capability to monitor } \\
\text { agreed changes in near } \\
\text { time }\end{array}$ & $\begin{array}{l}\text { - Health management in- } \\
\text { formation system (MIS) } \\
\text { - Disease registries for a } \\
\text { wide range of patient } \\
\text { types to support proactive } \\
\text { Health care } \\
\text { - Health analytics }\end{array}$ & $\begin{array}{l}\text { - } \text { MIS } \\
\text { - Clinical data standards }\end{array}$ \\
\hline $\begin{array}{l}\text { Payment systems - (that } \\
\text { benefit both health care } \\
\text { providers and third party } \\
\text { payer organizations) }\end{array}$ & $\begin{array}{l}\text { - More accurate billing } \\
\text { - Streamlined automatic bill- } \\
\text { ing, payment system } \\
\text { - Documentation of billing, } \\
\text { payment actions } \\
\text { - Operations and record } \\
\text { keeping efficiency } \\
\text { - Fraud protection }\end{array}$ & $\begin{array}{l}\text { - Electronic patient regis- } \\
\text { tration system } \\
\text { - Hospital management } \\
\text { system (including a cod- } \\
\text { ing; claims reimbursement } \\
\text { Module, billing) } \\
\text { - EPRs and EHRs } \\
\text { - Health information } \\
\text { exchange } \\
\text { - Health insurance manage- } \\
\text { ment software (including } \\
\text { expenditure monitoring) } \\
\text { - Patient management and } \\
\text { registration software } \\
\text { - Clinical coding and cost- } \\
\text { ing software }\end{array}$ & $\begin{array}{l}\text { - Coding and perfor- } \\
\text { mance standards for } \\
\text { payment and billing } \\
\text { systems } \\
\text { - Master patient index/ } \\
\text { health client registry/ } \\
\text { unique patient ID/ } \\
\text { health facility registry/ } \\
\text { health worker registry } \\
\text { - Agreed costs for treat- } \\
\text { ing agreed diagnostic } \\
\text { groups }\end{array}$ \\
\hline Financial management & $\begin{array}{l}\text { - Greater efficiency and } \\
\text { Equity, transparency, and } \\
\text { accountability } \\
\text { - Regular reviews to match } \\
\text { supply and demand } \\
\text { - More reliable data for } \\
\text { costing }\end{array}$ & $\begin{array}{l}\text { Financial MISs, e.g., for } \\
\text { budget formulation, ex- } \\
\text { ecution, accounting, and } \\
\text { reporting. } \\
\text { - e-Procurement, payroll, } \\
\text { debt management } \\
\text { - Supply and demand } \\
\text { models }\end{array}$ & $\begin{array}{l}\text { - Financial management } \\
\text { standards } \\
\text { - Data warehouses }\end{array}$ \\
\hline Research & $\begin{array}{l}\text { - (From all the sources } \\
\text { above) generate insights } \\
\text { into health threats and } \\
\text { Health care opportunities } \\
\text { - Reduced repetitive and } \\
\text { costly primary research and } \\
\text { manual data collection and } \\
\text { analysis }\end{array}$ & $\begin{array}{l}\text { Development of big data } \\
\text { marts that can be lever- } \\
\text { aged for research } \\
\text { - Health data analytics }\end{array}$ & $\begin{array}{l}\text { - Information govern- } \\
\text { ance (e.g., concerning } \\
\text { identifiable data, and } \\
\text { marketing) } \\
\text { - Data warehouses }\end{array}$ \\
\hline $\begin{array}{l}\text { Health care policy and } \\
\text { planning }\end{array}$ & $\begin{array}{l}\text { (From all the sources } \\
\text { above) develop better-in- } \\
\text { formed health care policies, } \\
\text { strategy. business cases, } \\
\text { and investments }\end{array}$ & $\begin{array}{l}\text { - Supply and demand } \\
\text { models } \\
\text { - Business case models }\end{array}$ & - Data warehouses \\
\hline
\end{tabular}


Appendix 4 Table: continued

\begin{tabular}{|c|c|c|c|}
\hline Opportunities & $\begin{array}{l}\text { Opportunities for } \\
\text { Saving Costs and } \\
\text { Increasing Benefits }\end{array}$ & $\begin{array}{l}\text { Technical Solutions and } \\
\text { Investments Required }\end{array}$ & $\begin{array}{l}\text { Basic Infrastructure and } \\
\text { Registries (in addition to } \\
\text { electricity and networks) }\end{array}$ \\
\hline \multicolumn{4}{|c|}{ D. Opportunities for Health Care Organizations } \\
\hline $\begin{array}{l}\text { Understanding the health } \\
\text { needs and demands of } \\
\text { populations }\end{array}$ & $\begin{array}{l}\text { - Better budgetary control, } \\
\text { stewardship, and govern- } \\
\text { ance } \\
\text { - Real time updates on ser- } \\
\text { vices provided to defined } \\
\text { populations } \\
\text { - Electronic health surveys } \\
\text { and faster access to infor- } \\
\text { mation } \\
\text { - Spatial analyses } \\
\text { - Early warning of health } \\
\text { security threats }\end{array}$ & $\begin{array}{l}\text { - Mobile data collection } \\
\text { (devices and training). } \\
\text { Tools for data analysis } \\
\text { and acquiring data from } \\
\text { providers (e.g., for govern- } \\
\text { ment agencies, nongov- } \\
\text { ernment organizations) }\end{array}$ & $\begin{array}{l}\text { - Geocoding standards } \\
\text { - Information governance } \\
\text { standards } \\
\text { - Databases and data } \\
\text { warehouses }\end{array}$ \\
\hline $\begin{array}{l}\text { Better strategic health } \\
\text { and health care impact }\end{array}$ & $\begin{array}{l}\text { More responsive health- } \\
\text { care that maximizes the } \\
\text { potential to save lives and } \\
\text { avoid some illness and } \\
\text { infections } \\
\text { - Potential to extend access } \\
\text { to unserved communities } \\
\text { - Potential to liberate some } \\
\text { existing resources for rede- } \\
\text { ployment } \\
\text { - Potential to leverage } \\
\text { predictive analytics to gain } \\
\text { insight into potential per- } \\
\text { formance improvements }\end{array}$ & $\begin{array}{l}\text { - Health information } \\
\text { systems that provide } \\
\text { community, local, district, } \\
\text { and national analyses with } \\
\text { the management informa- } \\
\text { tion required by the health } \\
\text { care organization }\end{array}$ & $\begin{array}{l}\text { Depending on the } \\
\text { nature of the health } \\
\text { care organization, full } \\
\text { suite of digital health } \\
\text { infrastructure }\end{array}$ \\
\hline Staff management & $\begin{array}{l}\text { - Ability to support, commu- } \\
\text { nicate with, and supervise } \\
\text { staff in real time. } \\
\text { - Improved management of } \\
\text { staff and other resources, } \\
\text { given ability to mine activ- } \\
\text { ity data to monitor staff } \\
\text { performance through vari- } \\
\text { ous filters, including at the } \\
\text { individual or aggregate level }\end{array}$ & $\begin{array}{l}\text { - Human resources man- } \\
\text { agement system } \\
\text { Resource mapping soft- } \\
\text { ware (facilities and health } \\
\text { workers, ideally linked to } \\
\text { Global Positioning System } \\
\text { data) }\end{array}$ & $\begin{array}{l}\text { - Standards for human } \\
\text { resources and perfor- } \\
\text { mance assessment } \\
\text { - Health worker registry } \\
\text { - Health facility registry }\end{array}$ \\
\hline Staff training & $\begin{array}{l}\text { Lower training costs with } \\
\text { online courses accessed } \\
\text { remotely and delivered at } \\
\text { scale. } \\
\text { - Improve effectiveness with } \\
\text { virtual peer-to-peer learn- } \\
\text { ing enabled } \\
\text { - Rapid deployment and of } \\
\text { online learning }\end{array}$ & $\begin{array}{l}\text { - Blended and online learn- } \\
\text { ing courses commissioned } \\
\text { - Commissioned content } \\
\text { (audiovisual) for use on } \\
\text { (BYOD) mobile devices } \\
\text { - Human resources system } \\
\text { with learning registers to } \\
\text { track learner engagement } \\
\text { - Apps to support im- } \\
\text { provements in learning } \\
\text { behaviors }\end{array}$ & $\begin{array}{l}\text { - Standards for human } \\
\text { resources and CPD } \\
\text { - BYOD policy } \\
\text { - Health worker registry } \\
\text { - Health facility registry }\end{array}$ \\
\hline
\end{tabular}


Appendix 4 Table: continued

\begin{tabular}{|c|c|c|c|}
\hline Opportunities & $\begin{array}{l}\text { Opportunities for } \\
\text { Saving Costs and } \\
\text { Increasing Benefits }\end{array}$ & $\begin{array}{l}\text { Technical Solutions and } \\
\text { Investments Required }\end{array}$ & $\begin{array}{l}\text { Basic Infrastructure and } \\
\text { Registries (in addition to } \\
\text { electricity and networks) }\end{array}$ \\
\hline $\begin{array}{l}\text { Supply chain manage- } \\
\text { ment }\end{array}$ & $\begin{array}{l}\text { - Avoid stock-outs } \\
\text { - Avoid excessive stock } \\
\text { levels } \\
\text { - Faster recovery from } \\
\text { supply-side disruption } \\
\text { - Fraud protection (e.g., fake } \\
\text { medicines) }\end{array}$ & $\begin{array}{l}\text { - Stock management } \\
\text { system } \\
\text { - Available need sup- ply } \\
\text { chain management sys- } \\
\text { tem (including cold chain } \\
\text { management of drugs) } \\
\text { - Bar-coded drugs (and } \\
\text { readers) } \\
\text { - Bar-coded medical and } \\
\text { surgical supplies (and } \\
\text { readers) }\end{array}$ & $\begin{array}{l}\text { - } \text { Medicine registry } \\
\text { - } \text { Drug registry } \\
\text { - } \text { supdical and surgical } \\
\text { - Drug and devices codes } \\
\text { and standards, with ap- } \\
\text { propriate bar codes }\end{array}$ \\
\hline Clinical audits & $\begin{array}{l}\text { - Continuous improvement } \\
\text { of quality of care } \\
\text { - Faster identification of } \\
\text { areas to improve } \\
\text { - More reliable rollout and } \\
\text { monitoring of changes }\end{array}$ & $\begin{array}{l}\text { - EPRs } \\
\text { - Disease-specific analytics }\end{array}$ & $\begin{array}{l}\text { - Agreed (performance } \\
\text { and) data standards } \\
\text { - Data warehouses }\end{array}$ \\
\hline Performance review & $\begin{array}{l}\text { Easier and more timely ag- } \\
\text { gregation of data by factors } \\
\text { including district, region, } \\
\text { provider, and disease. } \\
\text { - Better upward reporting }\end{array}$ & $\begin{array}{l}\text { - Health MIS } \\
\text { - } \text { Disease registries } \\
\text { - Health analytics }\end{array}$ & $\begin{array}{l}\text { - Clinical and manage- } \\
\text { ment performance } \\
\text { standards } \\
\text { - Data warehouses }\end{array}$ \\
\hline $\begin{array}{l}\text { Payment systems (that } \\
\text { benefit both health care } \\
\text { providers and third party } \\
\text { payer organizations) }\end{array}$ & $\begin{array}{l}\text { - More accurate billing } \\
\text { - Streamlined automatic bill- } \\
\text { ing, payment system } \\
\text { - Documentation of billing, } \\
\text { payment actions } \\
\text { - Operations and record } \\
\text { keeping efficiency } \\
\text { - Fraud protection }\end{array}$ & $\begin{array}{l}\text { - Electronic patient regis- } \\
\text { tration system } \\
\text { - Hospital management } \\
\text { system (including cod- } \\
\text { Ing, claims reimbursement } \\
\text { Module, billing) } \\
\text { - EPRs and EHRs } \\
\text { - Health information } \\
\text { - exchange } \\
\text { - Health insurance manage- } \\
\text { ment software (including } \\
\text { expenditure monitoring) } \\
\text { - Patient management and } \\
\text { registration software } \\
\text { Clinical coding and cost- } \\
\text { ing software }\end{array}$ & $\begin{array}{l}\text { - Coding and perfor- } \\
\text { mance standards for } \\
\text { payment and billing } \\
\text { systems } \\
\text { - Master patient index/ } \\
\text { health client registry/ } \\
\text { unique patient ID } \\
\text { health facility registry } \\
\text { health worker registry } \\
\text { - Agreed costs for treat- } \\
\text { ing agreed diagnostic } \\
\text { groups }\end{array}$ \\
\hline Financial management & $\begin{array}{l}\text { - Greater efficiency and } \\
\text { equity, transparency, and } \\
\text { accountability } \\
\text { - Regular reviews to match } \\
\text { supply and demand } \\
\text { - More reliable data for } \\
\text { costing } \\
\text { - Lower risk insurance costs }\end{array}$ & $\begin{array}{l}\text { - Financial MISs, e.g., for } \\
\text { budget formulation, } \\
\text { execution, accounting and } \\
\text { reporting } \\
\text { - e-Procurement, payroll, } \\
\text { debt management } \\
\text { - Supply and demand } \\
\text { models }\end{array}$ & $\begin{array}{l}\text { - Financial management } \\
\text { standards } \\
\text { - Data warehouses }\end{array}$ \\
\hline
\end{tabular}


Appendix 4 Table: continued

\begin{tabular}{|c|c|c|c|}
\hline Opportunities & $\begin{array}{l}\text { Opportunities for } \\
\text { Saving Costs and } \\
\text { Increasing Benefits }\end{array}$ & $\begin{array}{l}\text { Technical Solutions and } \\
\text { Investments Required }\end{array}$ & $\begin{array}{l}\text { Basic Infrastructure and } \\
\text { Registries (in addition to } \\
\text { electricity and networks) }\end{array}$ \\
\hline Research & $\begin{array}{l}\text { (From all the sources } \\
\text { above) generate insights } \\
\text { into health threats and } \\
\text { health care opportunities } \\
\text { - Reduce repetitive and } \\
\text { costly primary research and } \\
\text { manual data collection and } \\
\text { analysis } \\
\text { - Opportunities arising from } \\
\text { data analytics to do real } \\
\text { world testing of new treat- } \\
\text { ment regimes }\end{array}$ & $\begin{array}{l}\text { Development of big data } \\
\text { marts that can be lever- } \\
\text { aged for research } \\
\text { - Health data analytics }\end{array}$ & $\begin{array}{l}\text { - Information govern- } \\
\text { ance (e.g., concerning } \\
\text { identifiable data, and } \\
\text { marketing) } \\
\text { - Data warehouses }\end{array}$ \\
\hline $\begin{array}{l}\text { Healthcare policy and } \\
\text { planning }\end{array}$ & $\begin{array}{l}\text { (From all the sources } \\
\text { above) develop better in- } \\
\text { formed health care policies, } \\
\text { strategies. business cases, } \\
\text { and investments } \\
\text { Better strategic monitoring } \\
\text { and appropriate corrective } \\
\text { action }\end{array}$ & $\begin{array}{l}\text { - Supply and demand } \\
\text { models } \\
\text { - Business case models }\end{array}$ & $\begin{array}{l}\text { - Data warehouses } \\
\text { - Databases } \\
\text { - Analytical tools }\end{array}$ \\
\hline
\end{tabular}

Source: For further insights into many of these issues, see Celi et al 2017. 


\section{APPENDIX 5: JOURNEY TO BETTER DATA FOR BETTER HEALTH IN TANZANIA}

Tanzania has a population of 56 million. With support from the Bill \& Melinda Gates Foundation and as part of the Data Use Partnership, the Program for Appropriate Technology in Health has worked with the government and engaged 180 stakeholders (from the government, implementation partners, health teams, and facilities at all levels) to develop a set of 17 priority investment recommendations with specific activities, costs, and timelines for 2017-2023. The approach was guided by the hypothesis that "better data and regular data use will create a data use culture, leading to better decisions, an improved health system and improved health outcomes". Detailed cost estimates were made to:

(i) enhance service delivery,

(ii) strengthen health system performance,

(iii) optimize resource management,

(iv) improve data supply and demand, and

(v) connect and harmonize data systems.

These focus areas map the investment case framework, reflecting requirements from health managers, payers, donors, planners, and policymakers. But it is not evident that either the perspectives of the public and investors, nor that the potential synergies with the broader development agenda, are being addressed. Details of the costs and intended benefits do not demonstrate that improving stakeholder investment decisions is being considered. There is also no clear indication of how the government will build its in-house capacity to keep this work program managed.

Table A5: Investment Recommendation Cost Estimates (US\$ millions)

\begin{tabular}{|c|c|}
\hline Investment Recommendation & Total \\
\hline Computerize primary health care data & $\begin{array}{r}2.5 \\
31.8\end{array}$ \\
\hline Computerize hospital data & 13.1 \\
\hline Strengthen systems for facility performance, management, and supervision & 1.4 \\
\hline Implement systems for client feedback management & 1.0 \\
\hline Implement a health and social services workers registry & 1.2 \\
\hline Enhance systems for management of supply chain data & 1.5 \\
\hline Develop standards for health insurance eClaims & 0.4 \\
\hline Improve health management information system indicators and reporting & 6.9 \\
\hline Institute data use practices and capacity & 1.5 \\
\hline Enhance and scale a surveillance system for notifiable diseases & 4.1 \\
\hline Implement notification systems for birth and death recording & 1.7 \\
\hline Enhance government coordination of data systems and use initiatives & 0.2 \\
\hline Put in place an enterprise architecture, including governance, guidelines, and standards for interoperability & 1.2 \\
\hline Implement a client registry & 1.0 \\
\hline Implement a terminology service & 1.2 \\
\hline Implement an administrative area registry & 1.2 \\
\hline Implement a health data warehouse & 2.1 \\
\hline Grand Total & 74.0 \\
\hline
\end{tabular}

Sources: Authors and Program for Appropriate Technology in Health 2017. 


\section{REFERENCES}

Adler, A. 2016. MedCity News. https://medcitynews.com/2016/08/defining-digital-health-roi-5-elements-might-actually-make-sense/ (accessed 26 November 2017).

African Centre for eHealth Excellence. 2015. Advancing eHealth in Africa, African eHealth Forum. Kimberley.

Alabbasi, S. et al. 2015. Personal Health Book Application for Developing Countries. International Journal of Advanced Computer Science and Applications, 6 (2), pp. 120-128.

Alliance for Affordable Internet (A4AI). 2017. Affordability Report 2017. Washington, DC: A4AI and World Wide Web Foundation.

Anderson, A.E. et al. 2016. Electronic health record phenotyping improves detection and screening of type 2 diabetes in the general United States population: A cross-sectional, unselected, retrospective study. Jr Bimedical Informatics, 60, pp. 162-168.

Asian Development Bank (ADB). 2018. Transforming Health Systems through Good Digital Health Governance. Manila. http://dx.doi.org/10.22617/WPS189244-2.

Autor, D. 2015. Why Are There Still So Many Jobs? The History and Future of Workplace Automation. Journal of Economic Perspectives, 29 (3), pp. 3-30.

Black, A.D., et al. 2011. The Impact of eHealth on the Quality and Safety of Health Care: A Systematic Overview. PLoS Med8(1).

Bonnelye, G. M. 2015. The importance of real-world data to the pharma industry. https://www.pmlive.com/ pharma_thought_leadership/the_importance_of_real-world_data_to_the_pharma_industry_740092 (accessed 3 November 2017).

Braa, J. 2017. The DHIS2 Open Source Software Platform: Evolution Over Time and Space. In L. F. Celi, Global Health Informatics (p. 451). Cambridge, Massachusetts: MIT Press.

Broadband Commission. 2017. Digital Health: A Call for Government Leadership and Cooperation between ICT and Health. Geneva: International Telecommunications Union (ITU)/United Nations Educational, Scientific and Cultural Organization.

Brynjolfsson, E. M. 2014. The Second Machine Age: Work, Progress, and Prosperity in a Time of Brilliant Technologies. New York and London: W.W. Norton \& Company.

Bunn, T. 2017. Innovating transformative medical devices \& growing the local manufacturing sector. Global Health Innovation Accelerator CSIR Conference. Programme for Appropriate Technology in Health (PATH)/South African Medical Research Council.

Celi, L. F. 2017. Global Health Informatics: Principles of eHealth and mHealth to Improve Quality of Care. Cambridge, Massachusetts: MIT Press.

Chan, M. 2015. Health in 2015: From MDGs to SDGs. Geneva: World Health Organization (WHO).

de Dios, J. 2016. PH healthcare industry set for growth. net: http://business.inquirer.net/210155/ph-healthcare-industry-set-for-growth (accessed 8 January 2018). 
Digital Green. 2017. Community videos by the community for the community. Retrieved October 31, 2017 from http://www.digitalgreen.org/videos/

Digital Principles Forum. 2017. Principles for Digital Development. Retrieved November 11, 2017 from https://digitalprinciples.org/

Dobrev, A. et al. 2008. Methodology for evaluating the socioeconomic impact of interoperable EHR and ePrescribing systems. EHR IMPACT June 2008. European Commission, DG INFSO \& Media.

Dobrev, A. et al. 2010. Interoperable eHealth is Worth Securing Benefits from Electronic Health Records and ePrescribing. European Commission, DG INFSO \& Media .

Duffus, E. L. 2015. Smart ICT Investment for CRVS A Global Business Case. Plan International, WHO, UNICEF.

English in Action. 2017. English in Action is using mobile phones, the internet, print-materials, television, and peer-to-peer learning to help 25 million Bangladeshis improve their English as a route into work and out of poverty. Retrieved October 31, 2017 from https://www.eiabd.com/about-eia/eia-introduction. html

Gartner. 2017. Gartner Hype Cycle. (Gartner Hype Cycle Research Methodology.) Retrieved October 31, 2017 from https://www.gartner.com/technology/research/methodologies/hype-cycle.jsp

Global eSustainability Initiative. 2016. \#System Transformation: How digital solutions will drive progress towards the Sustainable Development Goals. Global eSustainability Initiative/Accenture Strategy.

Global Health Media. 2017. Creating videos to train health workers and serve communities worldwide. Retrieved October 31, 2017 from https://globalhealthmedia.org/

Government of Denmark. 2013. Making eHealth Work: National Strategy for Digitalisation of The Danish Health-care Sector 2013-2017. Copenhagen: The Danish Government Local Government Denmark Danish Regions.

Government of Tanzania/PATH. 2017. The Journey to Better Data for Better Health in Tanzania 2017-2023. Data Use Partnership. New York: Health Data Collaborative.

Green, M. 2007. Digital Health in Canada: Transforming Health Care through Innovation. A Conversa-tion about Digital Health. Canada Health Infoway.

Group, W. C. 2015. Expanding Participation and Boosting Growth: The Infrastructure Needs of the Digital Economy. Geneva: World Economic Forum (WEF).

Global System for Mobile Communications (GSMA). 2017. Scaling digital health in developing markets. London.

Health Data Collaborative. 2017. Data for health and sustainable development. https://www.healthdatacollaborative.org/ (accessed 4 November 2017).

High-Level Commission on Health, Employment and Economic Growth. 2016. Working for health and growth: investing in the health workforce. Geneva: WHO.

Hinton, B. S. 2016. Hadoop in Healthcare: Getting More from Analytics. Salt Lake City, Health Catalyst. 
HM Treasury. 2015. Public Sector Business Cases Using the Five Case Model Green Book Supplementary Guidance on Delivering Public Value From Spending Proposals. London: HM Treasury United Kingdom (UK).

Hong, C. A. 2014. Toward Increased Adoption of Complex Care Management. The New England Journal of Medicine, 371, pp. 491-493.

Integrated Government Philippine Program. 2017. Department Circular: Cloud First Policy. http://www.i.gov. ph/policies/signed/department-circular-cloud-first-policy/ (accessed 3 November 2017).

iHeed. 2017. Transcending Boundaries, Transforming Medical Education. http://iheed.org/en/home (accessed 31 October 2017).

International Trade Administration. 2016. Top Markets Report Health IT Country Case Study - South Korea. Washington, DC.

Jimenez, J. 2016. Three ways the Fourth Industrial Revolution can transform healthcare. Geneva: WEF.

Johnston, D. 2017. Digital Maturity: are we ready to use technology in the NHS? Future Healthcare Journal, 4 (3), pp. 189-192.

Jones, T. 2014. Making the Economic Case for eHealth. In M. W. Rosenmöller, Managing eHealth: From Vision to Reality (pp. 259-273). \{City\}: Palgrave Macmillan UK.

Kaneda, T. 2006. Health Care Challenges for Developing Countries with Aging Populations. \{City\}: Population Reference Bureau.

Kern, I. E. 2014. The Patient-Centered Medical Home, Electronic Health Records, and Quality of Care. Annals of Internal Medicine.

Khalil, S. 2017. NHS could have fended off Wannacry disruption says NAO report. https://www.digitalhealth. net/2017/10/62700/ (accessed 11 November 2017).

Khosla, V. 2012. Technology will replace $80 \%$ of what doctors do. http://fortune.com/2012/12/04/technology-will-replace-80 -of-what-doc-tors-do/ (accessed 3 November 2017).

Kieny, M.-P. E. 2017. Strengthening health systems for universal health coverage and sustainable development. Bulletin of the World Health Organization, 95, pp. 537-539.

Klein, G. 2014. Scientist shares insights on decision making. https://www.army.mil/article/130337/Scientist_ shares_insights_on_decision_making/ (accessed 7 November 2017).

Krawiec, R. J. et al. 2016. Blockchain: Opportunities for Healthcare. Deloittes.

Kuratis, V. 2009. What's a Network Industry? Is Healthcare One? http://e-caremanagement.com/whats-anetwork-industry-is-healthcare-one/ (accessed 4 November 2017).

LeFevre A.E. et al. 2017. Defining a staged-based process for economic and financial evaluations of $\mathrm{mHealth}$ programs. Cost Effectiveness and Resource Allocation, 15 (5).

Lopes-Casasnovas, G. R. 2005. Health and Economic Growth: Findings and Policy Implications. New York: MIT Press. 
Mutation Annotation \& Genome Interpretation. 2017. http:// magi.brown.edu/ (accessed 31 October 2017).

Masters R, A. E. 2017. Return on investment of public health interventions: a systematic review. Journal of Epidemiology \& Community Health o: pp. 1-8.

McCann, D. 2012. A Ugandan mHealth Moratorium Is a Good Thing. https://www. ictworks.org/ugandanmhealth-moratorium-good-thing

McDonald, C. 2017. 5 Big Data Trends in Healthcare for 2017. https://mapr.com/blog/5-big-data-trendshealthcare-2017/ (accessed 12 November 2017).

McMichael, A. 2017. Climate Change and the Health of Nations. Oxford: Oxford University Press.

Messner, J. 2017. The Fragile States Index. Washington, DC: Fund for Peace.

Monitor. 2015. Moving healthcare closer to home: Literature review of clinical impacts. London.

Muir, E. 2013. What is 'FHIR' and why should you care? https://blog.interfaceware.com/what-is-fhir-andwhy- should-you-care/ (accessed 11 November 2017).

Murphy, T. 2017. Secondary Use Data Project (SUDP). http://www.aihealthsolutions.ca/initiatives-partnerships/secondary-use-data-project/ (accessed 10 November 2017).

Mutation Annotation \& Genome Interpretation. 2017. Mutation Annotation \& Genome Interpretation. Retrieved October 31, 2017 from http://magi.brown.edu/.

O'Connell, T. R. 2014. What does universal health coverage mean? The Lancet, 383, pp. 277-279.

Oh, H. R. 2005. What Is digital health (3): A Systematic Review of Published Definitions. Journal of Medical Internet Research, 7 (1).

Peppard, J. 2016. A Tool to Map Your Next Digital Initiative. Harvard Business Review, pp. 1-6.

Pitchford, N. 2015. Development of early mathematical skills with a tablet intervention: a randomized control trial in Malawi. Frontiers in Psychology, 6, pp. 1-12.

Price, L. 2017. The Digital Health Hype Cycle 2017. https://www. healthcare.digital/single-post/2017/09/17/ The-Digital-Health-Hype- Cycle-2017 (accessed 31 October 2017).

Price Waterhouse Coopers. 2017. The Digital Healthcare Leap. \{City\}.

Raghupathi, W. A. 2014. Big Data Analytics in healthcare: promise and potential. Health Information Science and Systems, 2 (3), pp. 1-10.

Rajan, R. et al. 2013. MAMA 'Aponjon' Formative Research Report. Baltimore, MD, USA: Johns Hopkins University Global mHealth Initiative.

Rasmussen, B. S. 2016. Health and the Economy: The Impact of Wellness on Workforce Productivity in Global Markets. Washington DC: US Chamber of Commerce. 
Report of the High-Level Commission on Health Employment and Economic Growth. 2016. Working for health and growth: investing in the health workforce. Geneva: WHO.

Ritz, D. 2017. Making the case for Digital Health. Manila: Asia eHealth Information Network.

Roehrich, J. K. 2014. Are public-private partnerships a healthy option? A systematic literature review. Social Science \& Medicine, 113, pp. 110-119.

Roth, S. L. 2015. Universal Health Coverage by Design.. Manila: ADB.

Royston, G. 2017. Assessment of mHealth applications for their potential to provide essential healthcare information for citizens in low resource settings. \{City\}: Healthcare Information for All.

Schmidt, K. 2015. Engaging citizens in science. http://www.scidev.net/asia-pacific/health/scidev-net-atlarge/engaging-citizens-in-science.html (accessed 3 November 2017).

Schwab, K. 2016. The Fourth Industrial Revolution: what it means, how to respond. Geneva: WEF.

Schweitzer, J. A. 2012. The economics of eHealth and mHealth. Jr of Health Communication, 17, pp. 73-81.

Scientific Animations Without Borders (SAWBO). 2017. Scientific Animations Without Borders - Women's Empowerment. http://sawbo-animations.org/index.php?clk=Women\%27s+Empowerment (accessed 31 October 2017).

Snowden, A. S. K. 2012. Measuring What Matters: The Cost vs. Values of Health Care. \{City\}: International Centre for Health Innovation, Western University.

Standards and Interoperability Lab for Asia. 2017. Costing tool for OpenHIE Implementation. \{City\}.

Statista. 2017. The Statistics Portal. https://www.statista.com/out-look/312/122/ehealth/malaysia\# (accessed 30 October 2017).

Stroetmann, K. A. 2011. European countries on their journey towards national eHealth infrastructures. Brussels: European Commission.

Stroetmann, K. J. 2006. eHealth is worth it: The economic benefits of implemented eHealth solutions at ten European sites. Brussels: European Commission.

Tarr, G. W. E. 2014. Paper Health Registers Project Case Study: Ghana's Simplified Registers. Seattle: University of Washington (Global Health Start Program: Report to the Bill \& Melinda Gates Foundation).

The Health Foundation. 2010. Complex Adaptive Systems. London.

Thrimbleby, H. 2013. Technology and the future of healthcare. Journal of Public Health Research, 2, pp. $160-167$.

Toon, J. 2017. Team Demonstrates Digital Health Platform for Department of Veterans Affairs. https://gtri. gatech.edu/news-room/team-demonstrates-digital-health-platform-department-veterans-affairs (accessed 10 November 2017).

UHC2030. 2017. Healthy systems for universal health coverage - a joint vision for healthy lives. Geneva: WHO and World Bank. 
United Nations Department of Economic and Social Affairs (UN-DESA). 2016. United Nations E-Government Survey. New York (p.10).

UN-DESA. 2017. Sustainable Development Goal 3 - Ensure healthy lives and promote well-being for all at all ages. https://sustainabledevelopment.un.org/sdg3 (accessed 5 November 2017).

UN-DESA. 2017. Sustainable Development Knowledge Platform. https://sustainabledevelopment.un.org/ (accessed 5 November 2017).

United States Agency for International Development (USAID), Systems for Improved Access to Pharmaceuticals and Services (SIAPS), and Village Reach. 2015. Decreasing the Data Burden at the Last Mile to Improve Data Management and Use for Stronger Pharmaceutical Systems. \{City\}.

US Department of Health and Human Services. 2015. Top 10 Tips for Cybersecurity in Health Care. \{City\}.

USAID, SIAPS, and Village Reach. 2015. Decreasing the Data Burden at the Last Mile to Improve Data Management and Use for Stronger Pharmaceutical Systems. \{City\}.

Watts, N. et al. 2015. Health and climate change: policy responses to protect public health. The Lancet, 386 (10006), pp. 1861-1914.

West, D. 2015. Using mobile technology to improve maternal health and fight Ebola: A case study of mobile innovation in Nigeria. Washington, DC: The Centre for Technology Innovation at Brookings.

WHA69/24. 2016. Strengthening integrated people-centred health services. Geneva: WHO.

WHO/ITU. 2012. National eHealth Strategy Toolkit. Geneva .

WHO/MA4Health. 2015. Five Point Call to Action on strengthening Country Health Information Systems. Geneva.

World Bank. 2007. What is a Health System? Washington, DC.

World Bank. 2016. Digital Dividends. Washington, DC.

World Bank. 2016. Global Financing Facility: Note on Investment Cases. Washington DC.

World Bank. 2017. Public Private Partnerships Reference Guide Version 3. Washington, DC.

World Bank. 2017. World Development Indicators 2017 Maps. Washington, DC.

WEF/Bain \& Co. 2016. Maximizing Healthy Life Years: Investments that Pay Off. Geneva.

WEF/Boston Consulting Group. 2015. Expanding Participation and Boosting Growth: The Infrastructure Needs of the Digital Economy. Geneva.

WHO. 2014. What is universal health coverage? Geneva.

WHO. 2016. Global diffusion of eHealth: making universal health coverage achievable. Report of the third global survey on eHealth. Chapter 8. Big Data. Geneva. 
WHO. 2016. Global diffusion of eHealth: making universal health coverage achievable. Report of the third global survey on eHealth. Chapter 7. Social Media. Geneva.

WHO. 2016. Monitoring and evaluating digital health interventions: a practical guide to conducting research and assessment. Geneva.

WHO. 2017. Universal Health Coverage and Ageing. http://www.who.int/ageing/health-systems/uhc-ageing/en/ (accessed 31 October 2017).

Wyber, R. E. 2015. Big data in global health: improving health in low and middle income countries. Geneva: World Health Organization. 


\section{Guidance for Investing in Digital Health}

Digital technologies are increasingly underpinning almost all aspects of daily life, including health care. The overarching goal is to meet the Sustainable Development Goals, particularly universal health coverage, by investing in digital health. Health care systems have begun to embrace the transformative power of information and communication technology to spur better informed decisions by people and health workers in rural areas and hospitals. Many digital health solutions are already in place, and many are planned. This publication helps identify investments in knowledge, people, policies, and equipment that will maximize the impact of digital health. It presents a digital health impact framework to illustrate how to assess costs, benefits, and timescales; manage expectations; and ensure affordable strategies.

\section{About the Asian Development Bank}

ADB's vision is an Asia and Pacific region free of poverty. Its mission is to help its developing member countries reduce poverty and improve the quality of life of their people. Despite the region's many successes, it remains home to a large share of the world's poor. ADB is committed to reducing poverty through inclusive economic growth, environmentally sustainable growth, and regional integration.

Based in Manila, ADB is owned by 67 members, including 48 from the region. Its main instruments for helping its developing member countries are policy dialogue, loans, equity investments, guarantees, grants, and technical assistance. 